\title{
FRUIT HARVESTING
}

STORING, MARKETING

\section{F. A. WAUGH}

s)

ता 


\section{The 想. 直. AHill Tithrary}

Aorth Turaliua State Tollege

$$
\begin{aligned}
& \text { SB360 } \\
& W 35 \\
& \hline
\end{aligned}
$$


THIS BOOK IS DUE ON THE DATE INDICATED BELOW AND IS SUBJECT TO AN OVERDUE FINE AS POSTED AT THE CIRCULATION DESK.

SEP -21956

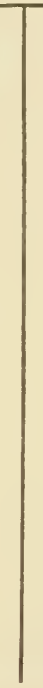



FRUIT HARVESTING STORING, MARKETING 


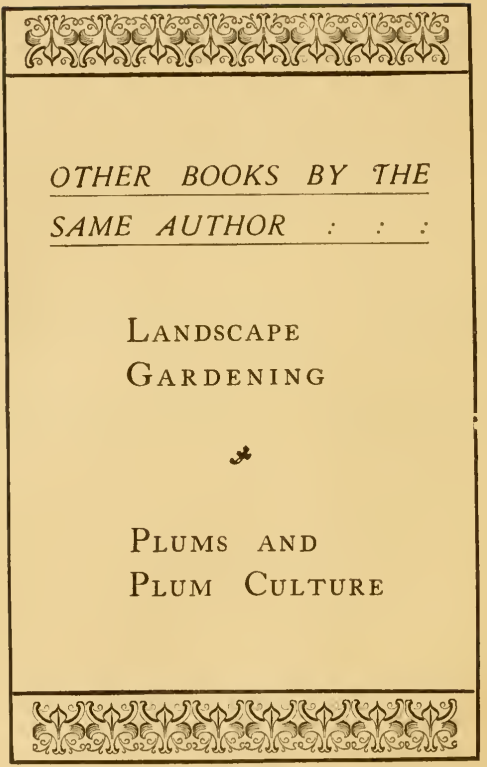




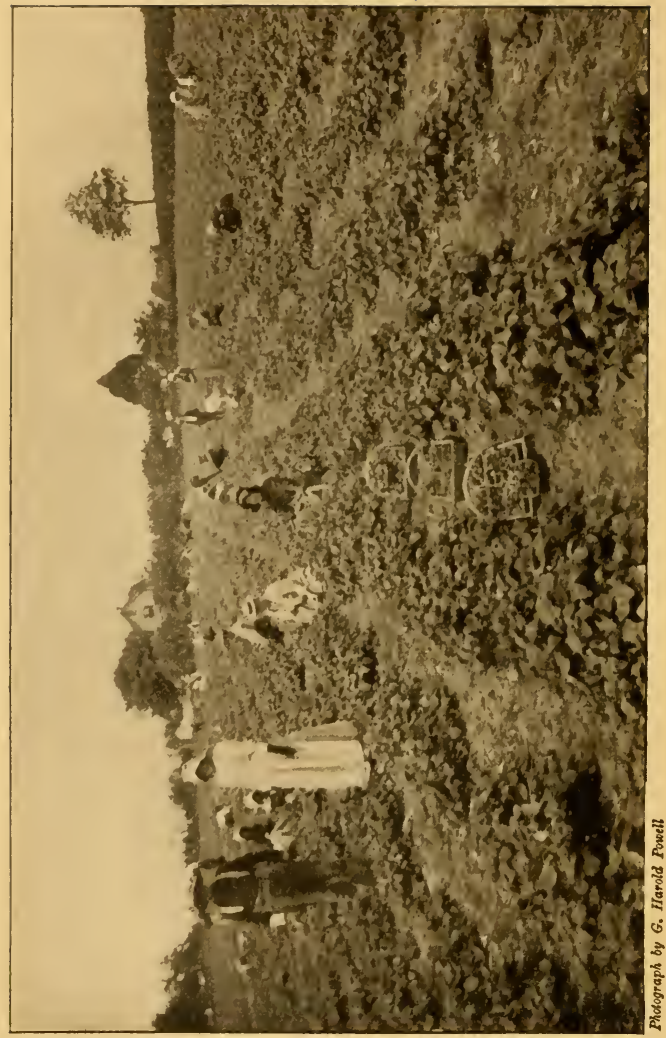

 
FRUIT HARVESTING

\title{
STORING, MARKETING
}

A PRACTICAL GUIDE TO THE PICKING, SORTING, PACKING, STORING, SHIPPING, AND MARKETING OF FRUIT $: \quad: \quad: \quad: \quad: \quad:$

\author{
BY \\ F. A. WAUGH
}

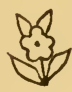

ILLUSTRATED

\author{
NEW YORK \\ ORANGE JUDD COMPANY \\ I 906
}




\section{COPYRIGHT}

ININETEEN HUNDRED AND ONE

13)

F. A. WAUTGH 


\section{TABLE OF CONTENTS}

\section{PART ONE-THE FRUIT MARKET}

I. The Two Markets

II. The Market Problems . . . . . . . 6

III. Commission Men . . . . • • . . 8

IV. The Foreign Market . . . . . . . . 12

V. Selling Associations-Pools . . . . . . 17

VI. The Home Market . . . . . . . . 22

VII. Production and Price . . . . . . . 25

VIII. Utilization of Wastes . . . . . . . . 3 I

\section{PART TWO-PICKING}

I. Time to Pick . . . . . . . . . 43

II. Picking Receptacles . . . . . . . . 46

III. Stems On or Off . . . . . . . . . 47

IV. Conveniences and Inconveniences . . . . 48

V. Managing Pickers . . . . . . . . 52

\section{PART THREE-GRADING AND PACKING}

I. The Practice of Grading . . . . . . . . 60

II. What is First-grade Fruit? . . . . . . 6I

III. The Designation of Grades . . . . . . 63

IV. Sorting Tables . . . . . . . . . . 65

V. Good Judgment in Grading . . . . . . 66

VI. Filling the Package . . . . . . . . 67

PART FOUR-THE FRUIT PACKAGE

I. The American Fruit Package . . . . . 73

II. The Apple Barrel . . . . . . . . . 74

III. Berry Packages . . . . . . . . 77

IV. The Grape Basket . . . . . . . . 79

V. Peach Packages . . . . . . . . . 80

VI. Apples in Boxes . . . . . . . . . 83

VII. Other Fruits and Packages . . . . . . 86 
V11I. Summary of Packages . . . . . . . 88

IX. Wrapping Fruits . . . . • . . . 89

X. Marks on Packages . . . . . . 89

PART FIVE-FRUIT STORAGE

I. Requirements • • • • • • • 95

II. Systems of Storage . . • . . . . . 97

III. Handling the Fruit . . . . . . . . 109

IV. Temperatures.$\quad$. . . . . . . IIO

V. Grape Storage . • . . • • • . . II2

VI. Storing Vegetables . . . . . . . . IIt

VII. Storage in Pits . . . . . . . . . 117

VIII. Storage in "Dugouts" or "Caves" . . . I2I

IX. Mr. T. L. Kinney's House . . . . . . 124

X. A Canadian Fruit House . . . . . . I28

XI. Professor AIwood's Storage House. . . . I3I

XII. A Nova Scotia House . . . . . . . 135

XIII. Mr. T. B. Wilson's House . . . . . . I4I

XIV. Mrs. L. E. Allen's Storage House . . . . I44

$\mathrm{XV}$. Notes on Various Storage Houses . . . . I 46

XVI. Design for Simple Lean-to Storage . . . 155

XVII. Design for Commodious Hillside Storage . . 157

XVIII. Design for a Thousand-barreI Storage House . I6I

XIX. Special Design for Arthur H. Hill . . . . 165

\section{PART SIX-APPENDIX}

I. Imports and Exports of Fruits, United States . I7x

II. Exports of Apples from Canada . . . . 175

III. State Fruit-package Laws . . . . . . I76

IV. Apple Shippers' Rules . . . . . . . IS6

V. The National League of Commission Merchants of the United States . . . . . . I 89

VI. Commission Charges . . . . . . . 206

VII. Shipment in Refrigerator Cars . . . . 206

VIII. The Apple Crop and Market . . . . . 212

IX. The Cranberry Crop . . . . . . . 217

X. Handling Southern Grapes . . . . . 220

INDEX . . . . . . . . . . 223 
PART ONE

The Fruit Market 



\section{THE FRUIT MARKET}

IT is of prime importance that the man who expects to grow fruit for sale shall understand the fruit market and its requirements. For this reason the discussion of picking, grading, packing, storing, shipping, etc., may be postponed until this more fundamental matter has been investigated. When one knows where his fruit is going and what is to be expected of it, he can the more intelligently prepare to meet the needs and the whims of his customers.

Fruit growing for market has increased enormously in extent, and has greatly advanced in its methods during the past twenty years. At the present time it employs vast sums of capital, furnishes a livelihood to armies of men, and yields, on the whole, tremendous profits.

The most characteristic development of the fruit industry in the United States has been along the lines of the wholesale trade, the peculiarities of which are set forth below. At the present time it is unquestionably true that America leads the world in the production of fruit in large quantities and in the perfection with which this fruit is distributed to distant points.

The fruit business in general in the United States 
has increased in much greater proportion than other agricultural industries. The following figures, showing the percentage of increase in total production of various agricultural crops in the United States between I 850 and I 897 , are compiled from a chart in Fairchild's Rural Wealth and Welfare:*

PER CENT INCREASE

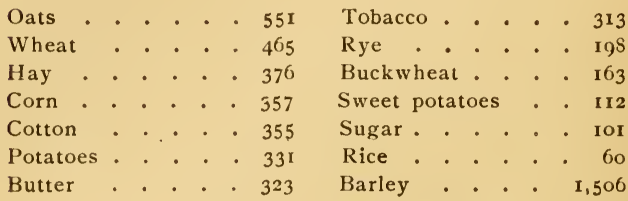

Fruits . . 2,000

The increase of total population in the country during the same period was 270 per cent.

But while the increased production of fruit in the United States as a whole has been thus enormous, it has been proportionately still greater in the recognized fruit sections. Fifty years ago there were no fruit sections. Now there are neighborhoods practically given up to the growing of strawberries, other localities engaged almost exclusively in peach culture, and still other communities in which the apple is the staple crop. In the eastern states, near the large cities and in the neighborhood of manufacturing towns, the progress of the fruit growing industry is

* Fairchild, Rural wealth and Welfare, 11. New York, 1900. 
something marvelous. The following statistics* show something of the trend of agricultural affairs in Massachusetts:

VALUE OF AGRICULTURAL I'ROPERTY IN MASSACHUSETTS COMPARISON OF I 885 WITH I 895

$\begin{array}{cccc} & \text { Total value } & \text { Totalvalue } & \text { Pircent } \\ \text { Classification } & \mathbf{1} 885 & \mathbf{1} 895 & \text { ordecrease }\end{array}$

Total property . . \$216,230,550\$219,957,214 + 1.72

Land . . . . . II0,700,707 II0,271,859-0.39

Machines, implements,

etc. . . . . .

Buildings . . . . 74.418,218 77,920,357+4.71

Domestic animals, etc. . I7,055,I53 I4,854,4I7 - 12.90

$\tau$ Fruit-trees and vines. $6,658,482 \quad 7,924,878+19.02$ t

VALUE OF AGRICLLTLRAI, PRODLCTS IN MASSACHUSETTS COMPARISON OF I 885 WITH I 895

$\begin{array}{cccc} & \text { Total value } & \text { Totalvalue } & \text { Per cent } \\ \text { Classification } & \text { I } \$ 85 & \text { IS95 } & \text { ordecrease }\end{array}$

Total products . . . $\$ 47,756,033 \$ 52,880,431+10.73$

Dairy products . . I3,080,526 I6,234,049 + 24.II

Hay, straw, and fodder . I1,631,776 12,491,090 + 7.39

Cereals . . . . I,855,I45 I, IO4,578 - 40.46

+ Fruits, berries, and nuts 2.252,748 2,850,585 + 6.33

+ Vegetables . . . 5,227,194 6,389,533 + 22.24

+ Nursery products . . . $138,439 \quad 182,906+32.12$

+ Hothouse and hotbed

products . . . . 73,983 $97,227+31.42$

+ Greenhouse products . $688,8 \mathbf{I} 3 \quad \mathbf{1 , 7 4 9 , 0 7 0 + 1 5 3 . 9 2}$

Inasmuch as the derelopment of a fruit growing

* Census of Massachusetts, 1895, pp. 331-333. Massachusetts Bureau of Statistics and Labor. Boston, 1899 . 
industry is oftenest confined to a comparatively small locality or a single neighborhood, the statistics of smaller territories would be more instructive than the statistics of an entire state. Take, for example, the statistics of Plymouth County, Mass., drawn from the same source as the figures compiled above:

VALUE OF AGRICULTURAL PRODUCTS IN PLYMOUTH COUNTY, MASS. COMPARISON OF I 885 WITH I 895

$\begin{array}{cccc}\text { CLASSIFICATION } & \text { Total value } & \text { Total value } & \begin{array}{c}\text { Percent } \\ \text { increase } \\ \text { or decrease }\end{array}\end{array}$

$\begin{array}{lrrr}\text { Total products. . . } & \$ 2,343,878 & \$ 3,241,023 & +38.28 \\ \text { Dairy products. . . . } & 585,017 & 731,869 & +20.09 \\ \text { Hothouse and hotbed . } & 1,805 & 1,877 & +3.99 \\ \text { Greenhouse products } & 8,833 & 28,845 & +226.56 \\ \text { Nursery products. . . . } & 9,358 & 21,696 & +131.84 \\ \text { Fruits, berries, and nuts } & 172,144 & 694,984 & +303.72 \\ \text { Cereals. . . . . . } & 51,820 & 20,887 & -59.69 \\ \text { Hay, straw, and fodder } & 506,775 & 626,762 & +22.68\end{array}$

\section{THE TWO MARKETS}

The fruit markets of the United States may be divided rather sharply into two classes. The first of these may be called the indirect, general, or wholesale market. The second may be distinguished as the direct, special, or retail market. The two are very different in almost all their characteristics, and these differences are of inevitable weight to the fruit grower. Wherefore it will be profitable here to set forth these distinctions with the strongest and most convenient antithesis. The two markets differ, then, in the following particulars :

I. Quantity.-The general market handles fruits 
in large quantities; the special market in small quantities.

2. Margin of profit.-In the general market the profit on each bushel or quart or package is much less (usually) than in the special market.

3. Salesman.-The fruit grower who grows fruit in large quantities for the general market sells it through a commission man. He never reaches the final customer. The man who grows fruit in small quantities for a special market frequently, or usually, sells to the customer direct. He is his own salesman. He thus becomes more immediately responsible for his goods.

4. Competition.-In the general market one meets the competition of the world. The price of apples in London is influenced by the crop in Tasmania, New Zealand, Canada, or the United States. The price in London (sometimes) influences the price in New York. Missouri apples in the general market meet the apples from Virginia, Pennsylvania, Ohio, Michigan, and New York. In the special market the fruit grower meets only local competition; and when regular customers are secured, even this competition is eliminated.

5. Varieties.-The general market demands a few varieties. The private market demands more, and will accept an almost unlimited number. Furthermore, the general market demands standard varieties-those which are known, and which are commonly offered in such quantities as to have a regular rating. The private market cares not whether a variety is a standard or not, so it suits the customer. 
6. Quality.-The general market gives adequate consideration to appearance, but pays little attention to quality. Ben Davis and Kieffer, proverbially inferior in quality, are standard and profitable market sorts. In the direct or private market quality is a matter of first importance. Appearance counts for less.

7. Shipping quality.-Fruit for the general market must be such as will bear shipment and much rough handling. That for the private market need not submit to this test.

8. Package.-The wholesale market requires a standard package. Almost any neat, clean package may be used in the direct market, and sometimes fruit is delivered in bulk, from sacks, boxes, barrels or baskets, without any package. In the wholesale market a gift package is practically always required. The man who has private customers frequently has his boxes or baskets returned to him.

9. Season.-The general market accepts fruits only in season. There is no sale for Fameuse apples after Christmas, and no general sale for strawberries before April. The private market often pays extra for fruit out of season. The sales of strawberries which are made every year during January and February are made to special customers. Such berries do not come into the general market.

\section{THE MARKET PROBLEMS}

There are several successive problems which face the man who grows fruit for sale, whether he have in 
view the general or the special market. The principal problems are the following:

1. Growing the fruit. - The fruit must be grown before it can be sold, and fruit growing is a long, long art. Dozens and dozens of books have been written on this subject alone, which is one reason why we may devote this entire book to another subject. The production of fruit for market is quite a different problem from the growing of fruit for home use. It differs most conspicuously in the fact that the market grower must always count the expense to see that it is kept below the cash returns. The man who grows fruit for his own gratification may do so without regard to expense. (Sometimes he does it without much regard to the fruit!)

2. Grading.-Fruit for home use is seldom sorted and never graded. For market grading is indispensable. We shall devote a chapter to this subject.

3. Packing. - "The package sells the fruit" has come to be a fundamental doctrine of the American fruit trade. The selection of a suitable package and the attractive installation of the fruit in it are the best "tricks of the trade."

4. Storage.-All fruits, except those which are so perishable as altogether to prevent it, are frequently stored for longer or sliorter periods. This permits the grower (or buyer) to regulate the supply of fruit to suit the demand. Glutting of the market is prevented, and better prices are realized. The subject of storage is fully treated in Part $\mathrm{V}$. 
5. Transportation.-No other one condition so positively determines the nature, the localization, and the profits of fruit growing as transportation. Facilities and rates are both of paramount importance. This subject is one which does not admit of much generalization. Shipping facilities are different for every railroad station, and rates also vary considerably.

6. Discovery of the right market.-Finally the man who has fruit to sell must find the man who wants to buy it. Porter apples sell well in Boston, but are not wanted in New York; Tolman Sweet sells in Philadelphia, but can't be given away in Rochester. In a more general way it may be said that the man who has grown many fancy varieties for a special market must find his private customers. It will not do for him to ship to a city commission man. Equally the man who has grown large quantities of standard sorts, like Ben Davis and Kieffer, need not search for a fancy home trade. I know a man who has 1,000 to 2,000 barrels of fine apples every year, and who is disgusted that he can not sell them in his home town for as much as they will bring in New York. But the fact and the explanation is that his whole business is run on the general market plan.

\section{COMMISSION MEN}

Fruit which goes into the general or wholesale market is practically all handled through the mediation of the commission man. As the general market is the one most sought in America, it follows that the commission man has flourished and multiplied and replenished the earth. His presence seems to be ab- 
solutely necessary to the sale of fruit in large quantities, though growers have mostly come to regard his presence as a necessary evil. According to the ordinary practice, the grower ships his strawberries, his plums, or muskmelons to a certain commission man in the city-say to Murphy \& McBride, of Baltimore. Murphy \& McBride send a postal card acknowledging the receipt of the shipment, and specifying that the fruit was received in good or bad condition, as the case may be. When the fruit is sold they make their returns to the shipper. If Murphy \& McBride are honest and solvent the returns are made promptly, accompanied by a check for the balance due the shipper. The memorandum returned to the shipper shows the packages of fruit sold, the selling price of each lot, and the gross amount received. Express or freight charges are deducted, as is also the commission charged. The accompanying copy of an account sales will give a clearer idea of the transaction.

This arrangement works very well if the commission house is thoroughly honest, and if - a condition equally important - the fruit shipper is also honest. As soon as either one begins to cheat the whole basis of the business is immediately destroyed and the most deplorable results follow. Unfortunately the strenuous competition among commission men, as well as the profound duplicity of many consignors, forces every commission house with the least pregnable conscience into some form or other of cheating. The simplest trick, of course, is to sell a consignment of fruit for a hundred dollars and return only seventyfive. But there are hundreds of others quite as effect- 
IO FRUIT HARIESTING, STORING, MARKETING

ive and equally well known to the experienced fruit dealer. The result, as a whole, has been to give the commission men the reputation among fruit growers of a band of unprincipled thieves. Sometimes this

\section{Qbew Bak, of -3.}

\section{TN. KINNEY,}

\section{COMLOSSUON MELELANT,}

FRUITS, * PIROIDUCE, * ETC.,

276 WASHINGTON STREET.

Oela far lis r

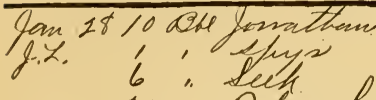

21: Dalman-hnet

52

Efupe

$\begin{array}{ll}20 & \\ 4 & 13\end{array}$

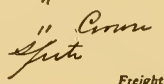

3003000

200 18.00

$350 \quad 52.50$

35018200

3259750

8009600

Freight, $3 5 9 6 4 \longdiv { 3 0 0 }$

Cartage, $\quad 672$

Commission, 48.309098

'Net Proceecs.,

FIG. I-ACCOUNT SALES FROM A NEW YORK COMMISSION HOUSF:

reputation is deserved. Much oftener it is not. Sonctimes the shipper is as bad as the commission man.

This organization of the fruit trade is certainly far from ideal. The shipper is completely at the mercy of the commission man. The whole bargain is on one side of the transaction. It will take a long time, however, to change matters to another system. The present writer certainly disclains any intention of offering a new system. If the following suggestions 
are carefully observed, however, it will go far toward mitigating the evils which one meets in dealing with commission men:

1. Stick to one man.-If it seems necessary to ship to two or three markets-as to Pittsburg, Philadelphia, and New York-stick to a single commission house in each city, but, as far as possible, ship to a single market. The man who is conducting business on a very large scale, like J. H. Hale or Roland Morril, and who can keep his hand on the commission 11en, can afford to transgress this rule. Such men are superior to all rules. Most of us are not. For the ordinary fruit grower and shipper this rule of dealing always with one commission firm is of the utmost consequence.

2. Ship the same varieties year after year, and make the grade just as uniform as possible. Even if something short of the best fruit is shipped, uniformity of grade is highly advantageous. The commission house knows what to expect, and custonners get used to the brand and the grade. There are hundreds of shippers growing all classes of fruits whose products are commonly already sold when they arrive in the market. Uniform and honest packing does it.

3. Select a brand which is neat, catchy, and not too large, and see that it goes on every package. Some men have made reputations and money out of their brands.

4. Grade and pack with the most rigid honesty.Don't try to cheat a commission man. It can't be 
done. The commission man has the last turn, and he is absolutely sure to protect himself, whatever happens to the shipper. Moreover, any evidence of dishonesty immediately destroys the dealer's confidence in that consignor, and selling is seriously interfered with. Thereafter packages must be opened and examined before they are sold, and they are not offered to the best customers.

5. Follow the advice of the commission man as far as possible when you have settled on a good one. Ship fruit when he wants it. Send the varieties and grades that he wants, and in every other feasible way conform to the requirements of his business. His business is the fruit grower's business. He is the fruit grower's agent. He should be treated as such.

\section{THE FOREIGN MARKET}

Before leaving the general subject of the wholesale market, it may be best to give some attention to the European outlet for fruit. There are considerable quantities of apples shipped from the United States to Europe every year, the larger majority going to England. A few shippers have their regular European customers, who require a certain quantity of American apples each year. The Albemarle Pippins of Virginia and the Newtown Pippins of New York are particular favorites in England with special buyers. There are hardly any of our hardy fruits except the apple, however, ever shipped out of the United States. Mr. Peter Barr, I remember, was very sure, when he was visiting here, that a good trade in American grapes could be built up in London by proper management. 
His belief is based on the best of reasons, but as yet there is no export business to speak of in this line.

Shipments of fruit from Canada to England and Scotland are more regular, and, at least comparatively,

TrLetupac Lookes " "WOMEWARO."

CORN.EXOHANGE BUILDINGS, 27 FENNEL STREET.

IDanchester, $31 \stackrel{\text { sl }}{-}$ Ochber 1900

ACCOUNT SALES of 319 Sackages Pears: - Enanchester hader \& . B.... hontreal __ sold for accoune of heans A. Al Detter rons

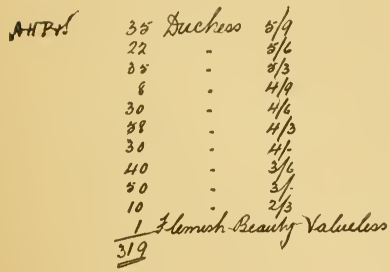

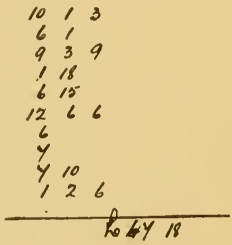

CHARGES :

Frenght

19,2

Duty Paid

Manchester Ship Canal Tulls and Quay Charges

Cartage and Porterage at Docks and Warehouring

Sampling and Taring

Clearing and Forwarding

Warchouse Hent

Pire Invurance

luterest on Freight
Brakerage

Pustages, dec.

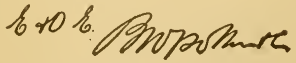

3 y $y$

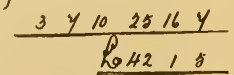

FIG. 2-ACCOUNT SALES OF CANADIAN APPLES SOLD IN 
are $m$ mcl greater. The Canadian home market, though unapproachably good in certain localities, is not, on the whole, at all equal to the large city markets of the States, either in capacity or liberality. This is one reason why exportation is commoner. Another reason lies in the closer political and trade connections between Canada and England; while a final and very important reason is that the Canadian government has systematically assisted in these exportations. Naturally the chief exports from Canada are apples. Nova Scotia, in particular, has a high reputation for its export apple trade. Other fruits, however, have been shipped to some extent, and in an experimental way a great many different things have been sent over, such as peaches, grapes, and tomatoes. While each one of these has been successfully shipped and sold in particular instances, no regular business has been established with any fruit except the apple. Possibly the pear comes nearest to being an exception, but the Canadian exportation of pears is still a small matter. Perhaps when the Canadian Kieffer orchards get to bearing, this will be changed.

In years of excessive crops, however, when the markets of the United States are over-supplied, the European outlet becomes a very important factor in the situation. This was most conspicuously the case in I 896, when the bumper apple crop of America was harvested. It seems perfectly certain, so far as we can know anything for the future, that there will never again be such a congestion and such a stressful competition in the fruit market. Certainly something was learned in 1896 concerning the European market, and 
whenever another large crop comes exportations will be more carefully and intelligently handled.

As a primary consideration it is plain that American shippers could take much better advantage of the European market if they could supply it more regu-

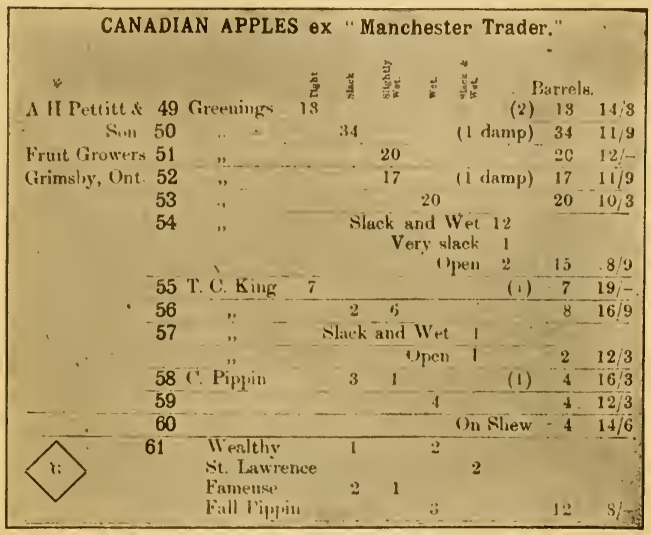

FIG. 3-REPORT OF SALES OF CANADIAN FRUITS AT MANCHESTER, ENGLAND, SHOWING "SLACKS" AND "WETS"

larly. Shipping a great quantity of fruit one year and leaving the market vacant the next year does not foster, but rather prevents, the establishment of a profitable business. Considerable markets for our apples were opened in continental Europe in $r 896$, and a horticultural friend of mine who traveled there in I 897 told me that there was a frequent call for Ameri- 
can apples and a general disappointment that none were offered. The crop of 1897 was short, however, and prices were so good in New York, Boston, Philadelphia, and Baltimore that nobody cared to take the risk of shipping to Germany. This is likely to be the situation at least for many years to come.

When shipments are made to the European market certain precautions are to be observed. First, only firm, solid fruit of fine appearance should be shipped. As in the general domestic market, ligh quality is not so important as attractive appearance. But the fruit must be the very best in shipping quality, and such as will sell for the highest price. This is imperative. Freights and other charges are so high that they consume the entire receipts from poor or mediocre fruit. It costs just as much to ship and sell a barrel of poor apples as a barrel of good ones, and it is only on the good barrel that there is enough left over to bring anything back to the shipper.

In the second place, considerably greater pains than usual must be taken in packing. The ocean voyage, often on a lurching, pitching ship, and the rough handling on the docks, severely test the best packing. If there is the least slack space the fruit immediately begins to be bruised, and, in many cases, arrives in the market a shapeless mess of mush. The circumstances would indicate the propriety of shipping fruit wrapped and packed in small packages. Unfortunately for the theory of it, this treatment has not been generally profitable with apples. Perhaps it will do better in the future.

In the third place, European shipments should be 
confined, as far as possible, to a few well-known and standard varieties. Ben Davis apples generally do well. Kieffer pears have not been well received; but there are too many good pears grown in Europe. Perhaps Kieffers will do better after the marketmen get accustomed to them.

\section{SELLING ASSOCIATIONS-POOLS}

The inherent weaknesses of the relation between fruit grower and commission man, and the very unsatisfactory result of that relation in special cases, have often led to earnest, almost desperate, effort to escape from the situation. There appear to be two favorite avenues of retreat. The first leads toward the special or private fruit market, and the man who follows it attempts to transfer his business to the basis of the personal or direct market. The situation as respects this personal market is fully discussed further on in this chapter. The second way of escape from the commission dealer leads in the direction of cooperative selling, selling associations, pools, and the like. In the latter case the business remains on the wholesale basis - the fruit growers still attack the general market.

Numerous associations of this character, some comprising only two or three neighbors, some involving large capital and considerable organization, have been formed in this country. On the whole, their experience has not been encouraging. Such organizations, however, are most admirable in theory (if one leaves out of consideration certain fundamental principles and looks only at external circumstances). The theoreti- 
cal reasons (all of them sound) usually urged in favor of cooperative marketing are about as follows:

I. Distribution.-An association of fruit growers can secure a better distribution of the crop. Instead of rushing all the fruits into one convenient market, as independent growers are apt to do, thereby causing a glut while leaving other markets vacant, the association can distribute the crop to suit the demand at all the various points within reach. In the case of perishable fruits, where rapid handling and quick sales are imperative, an association can maintain telegraphic communication with all the markets, and is thus enabled to ship to-day to one point and to-morrow to another, according to the fluctuating general supply at each point.

2. Salesmen.-An association can employ salesmen. These may be either traveling "drummers," who visit dealers hither and yonder, seeking an outlet for the fruit handled by the association, or they may be resident salesmen, who handle goods just as the commission houses do, but who work on a salary instead of at a commission.

3. Economy.-An association can operate more economically. Storage can be secured when needed. Men can be hired to better advantage. Fruit packages can be bought in large quantities at lower rates. Sometimes fertilizers are bought through the association, and other economies effected.

4. Transportation.-An association can secure better transportation rates. On account of the larger 
rolume of business, transportation companies will compete for the traffic; and even when competition amounts to little, material shipping concessions can sometimes be secured by an association having a considerable quantity of fruit to handle.

5. Grading.--An association can establish a uniform grade. If this could actually be done in practice it would be a matter of first consequence. Elsewhere the importance of uniform grading for the general market is elucidated more in detail. The fact is, however, that tremendous difficulties arise when an association endeavors to establish a standard grade; and these difficulties grow rapidly greater as the standard of grading is advanced. Nevertheless, whatever approach the association is able to make toward uniform packing and grading is an advantage to the business.

6. Command of the market.-Certain large markets are at the command of an association handling quantities of fruit, though the same markets will not handle small and irregular slipments.

7. Restriction of output.-An association, in certain cases, can influence prices in its own favor by controlling the output to some extent.

Many of these advantages are so obvious, and apparently so easy to attain, that the fruit-selling association has been a rather common experiment. There are three fundamental difficulties, however, in the way of their success, and the drawbacks have usually proved more powerful than the advantages. 
The principal troubles which have to be met are these :

I. Distrust. - All classes of farmers are constitutionally and proverbially distrustful of other people and of one another. In a fruit association there arise - such is the experience-the most inveterate jealousies. Each man thinks he is furnishing a better grade of fruit than his neighbor, though all share alike in the profits. Each one fears the other will reap some special advantage somehow. In particular, the appointment of managers, superintendents, supervisors of grading, shipping agents, and all other officials of the company, offers a sufficient opportunity for the elaboration of all sorts of neighborhood quarrels. Each man thinks he ought to be manager, and when one man is finally chosen he is usually suspected of all sorts of favoritism. In any case he is apt to be hampered in his business relations by committees, boards of directors, and various kinds of red tape and foolishness. Often he has to consult a committee before taking any important action. Think of J. H. Hale consulting a committee before selling a couple of carloads of peaches, or of 'T. B. Wilson calling a directors' meeting to see if he should accept or refuse $\$ 3.45$ a barrel for his apples! Most men don't even consult their wives!

Another difficulty which arises from the same cause is that the subscribers to such an association never want to pay a manager inanager's wages. Two or three dollars a day is considered good pay. Yet such a man is compelled at times to handle thousands 
of dollars' worth of business. The position is such as, in ordinary business life, would often command a salary of five thousand dollars a year or more.

2. Irregularity in grading.-Unless all the fruit can pass practically under the eye and through the hands of one man, it is impossible to preserve a uniform grade. If, as often happens, the sorting is done by a committee, selected more with a view to mollifying the feelings of sundry subscribers than to the expertness of the packers, then all sorts of grading result. Then the association sends out one grade of fruit to-day as XXX and another grade to-morrow under the same mark. This kind of business immediately destroys the confidence of the purchaser, while demand and price decrease. This difficulty of maintaining a uniform grade for a fruit association has proven, in practice, to be one of the most serious.

3. Inversion of competition. - In the ordinary course of trade, including the sale of fruit, the best fruit brings the most money and pays the largest profit. A man has every incentive, therefore, to grow the best fruit he can and to pack it as well as he knows how. When interests are pooled in a selling association, the poor fruit brings just as much as the good. The man who can squeeze in the poorest fruit, grown and handled at the least cost, thus makes the largest profit. The competition is thus turned from the production of the best fruit to the production of the worst. Every man tries to see how poorly he can do. The eternal law of progress, that law which provides for the survival of the fittest, is abrogated, and, temporarily, the 
preference goes to the unfittest. This matter is of such fundamental importance that, of itself, it is capable of overcoming all the theoretical advantages of cooperative organization enumerated above.

Cooperation has been successful in some cases; but the writer does not know of any conspicuous instance of such success, nor of any continuously successful organization on any scale.

\section{THE HOME MARKET}

To reach the general fruit market one has to grow the varieties which the market demands. In supplying the home trade one may cultivate the market to take what he has to offer. This difference sometimes amounts to a great deal. One may be able in this way to lead his customers to buy those things which he can produce most easily and profitably.

For the most part, the greatest success in the home market is reached when the fruit handled is of the highest possible quality. A few customers who will take an extra select grade at a fancy price are better than many customers who are satisfied with a secondrate fruit, but who will not pay more than the gree1grocer's price.

Fruit should be supplied regularly to personal customers in the home market. Buying fruit is merely a habit in many families, and the habit is most readily noticeable by its absence in the majority of households. If the fruit wagon stops every Tuesday and Saturday, or eren once a week, the mere regularity of the visit presently begins to sell sone goods.

Fruit slould also be supplied continuously through 
as long a season as possible. In the home market one can not depend on disposing of a large quantity at once, and the bulk of business must accrue through the extension of the season. This requires that the man who supplies the home market must grow a considerable variety of fruits. He should be able to start the season with strawberries, to follow these with raspberries, these with dewberries or blackberries, or both, these with cherries, these with early plums and green gooseberries, later to bring green apples and the first peaches, and so on through the year. Frequently certain vegetables can be handled to advantage with fruits, particularly such things as tomatoes, muskmelons, and the like. In general, however, the man who is most successful in fruit growing is not equally successful in vegetable growing. It is hardly good policy to try to handle a complete line of both fruits and vegetables. Onions and strawberries do not combine well.

Besides seeking to handle the best grades of fruit, the man who supplies his own private customers should use all pains to have everything as neat and clean as forethought and sapolio can make them. The baskets and packages should be fresh and spotless. The boy who comes to the door should wear a conspicuously white apron. The fruit should be delivered in a neat covered wagon, bearing just enough advertising and not too much. Everybody should know whose delivery wagon it is and what it carries; but no one should be able at a little distance to mistake the turnout for a traveling medicine outfit or the advertising wagon of a coming circus.

Announcement should always be made in advance 
of fruits that are coming into market. Let the deliveryman say, "We shall have some Shaffer raspberries next week. They are not very pretty, but they make A No. I shortcake;" or, "Next week we can bring you some Duchess apples. They are firstclass for sauce or jelly." I know one fruit grower who is very successful in a small local market, and who announces his wares in the local newspaper every week. His little advertisement says:

\section{JONES'S FRUIT FARM}

This week we have the last of the strawberries-big, fine, juicy Gandys, at 25 cents a quart. They're the last you get this year, and about the best. We also have some fine lettuce. Next week we shall offer the first raspberries, which will cost 35 cents a quart and will be worth it.

A good liberal price--not excessive-should be fixed each day for each grade of goods, and should not be cut under for any reason whatsoever. It is much better to carry the whole stock home and put it in the cannery or the dry-house than to allow the price to be liggled down. A man who expects to deal with the same customers month after month must be absolutely immovable at this point.

The matter of collections belongs to general business and is not properly a part of the fruit trade. Still, it is the most important part of the marketman's business, and should be managed with the utmost care. It is always best to insist on prompt and regular payments. 
It is better to sacrifice a liberal patron than to allow collections to get badly behind. The importance of this matter is proved by the experience of hundreds and hundreds of marketmen everywhere.

\section{PRODUCTION AND PRICE}

Orer-production is a word which has often been conjured with in the discussion of agricultural topics. It seems usually to have served for the confusion of the hearer and usually for the equal confusion of the speaker. Over-production is commonly used to mean two widely different things. In some cases it is intended to mean the production of more fruit or grain than can be consumed; in other cases it means merely the offer of more fruit or grain than the market will accept at the price asked.

In the former sense there is no such thing as overproduction of fruit, and probably not of any agricultural crop. It is said that there can be no over-production of wheat while thousands of people are hungry and starving. There are always plenty of people hungry for strawberries, even when the market is most hopelessly glutted. There is, absolutely speaking, no over-production; there is simply an over-supply.

The term over-supply ought to be substituted for over-production in almost all discussions, since oversupply is the thing usually discussed. The problem of over-production will never worry a fruit grower, but over-supply is one of his greatest dangers.

Over-supply is merely one of the extremes in the ever-fluctuating ratio of supply and demand. It should be considered, therefore, as incidental to the 
fundamental problem. Its real significance will appear more clearly in the course of the following study of demand, supply, and price.

Two entirely independent conditions influence the price of any commodity. The first is cost of production. In a general way, as every one knows, the price of an article must be determined by what it costs to make it. It costs more to produce a barrel of apples than to produce a quart of strawberries, and the apples necessarily sell for a correspondingly higher price.

But, aside from the cost of production, the relation of supply and demand determine the price. Prices increase with demand and diminish with supply. The mathematician would say that demand divided by supply gives price; or he would write it in the form of an equation, thus :

$$
P=\frac{d}{s}
$$

or he might say that price is the expression of the ratio between demand and supply. Whatever he might say it would be no clearer than the practical fact that when peaches are plenty the price goes down, and when they are scarce it goes up.

Now as the supply increases and price decreases, a point is reached presently where the market price equals cost of production. The margin of profit has been wiped out, and that market may properly be said to be over-supplied with the commodity in question. Sometimes fruit continues to be offered at prices below the cost of production, but such offerings can not long be continued. The cost of production thus 
forms the lower limit in the varying ratio of demand and supply.

Since price is the quotient of demand and supply, it follows that anything which influences either has a direct effect upon price. A study of the causes affecting prices thus becomes a study of the conditions affecting both supply and demand. As the question of price is the one lying nearest the fruit grower's pocketbook, we may properly examine these conditions in detail, even at the risk of being tedious.

The conditions affecting the market supply are production, transportation, information, perishability, storage.

I. Production.-The larger the crop, other things being equal, the greater the market offerings. The market was glutted with apples in 1896 simply because of large production. Peaches were scarce in the Boston wholesale markets in 1899 merely because very few peaches were raised that year. Production, in turn, depends on the weather-how much, every fruit grower knows-on frost and hail, or on timely rains. Production depends also on the ease with which a crop is grown. Anybody can grow applesthat is, some kind of apples; and that is why the apple market is so apt to be over-supplied in a good year. Very few people can grow nectarines or apricots, and, in consequence, an over-supply of these fruits is less likely to occur.

Production varies also with price. Higher prices stimulate production. Low prices diminish production. Thus our equation reacts upon itself. The mathe- 
matics of it are spoiled; but that ought not'to draw a complaint from the mathenatician, for the same circumstances have often spoiled the calculations of the fruit grower. This stimulation which high prices give to production tends to set a maximum limit on price -that is, to the varying ratio of demand and supply.

2. Transportation. - Next to production, transportation facilities chiefly determine the quantity of fruit offered in a given market. Increased transportation facilities, therefore, by bringing larger quantities of fruit to market, tend to depress prices. This rule is hardly open to exception; but it must be noted that though prices may be reduced, the grower's net profits may be increased.

3. Information. - The rapid circulation of information concerning markets tends powerfully to regulate the distribution of a fruit crop. It sometimes happens that the Cincinnati market is glutted with grapes on the very day when the people of Pittsburg are almost bereft of that comforting fruit. But where shippers are properly informed, these mistakes of distribution do not occur. This is one of the best features of selling associations or pools. See page i 8 .

4. Perishability. - The more perishable fruits show extreme fluctuations in supply. When strawberries are ripe they have to be sold; and as they ripen rapidly during hot weather and at the hight of the season, the supply increases enormously at such times.

5. Storage.-Facilities for fruit storage equalize the supply, making it less at the hight of the season and greater in succeeding weeks. 
The conditions affecting the demand for any given class of fruits are price, quality, acquaintance, season, supply of other fruits.

I. Price.-It has already been seen that price influences production, and so reacts on itself. But it influences demand still more, thus reacting doubly upon itself. Nothing else will move a quantity of fruit so quickly as an attractive reduction in price.

2. Quality.-Good fruit sells much more rapidly than poor fruit. The buyer who gets a good package of fruit will likely want another. Poor fruit is apt to lag in the market at any price.

3. Acquaintance.-Buyers call for those fruits with which they are acquainted. There is a steady demand for Baldwin apples and practically none for Sutton, though Sutton is a much fairer and better apple of the same season. The reason is that Baldwin is known to everybody, while Sutton is a stranger. A friend of mine had to give away his De Soto plums the first year because nobody knew what they were; but the succeeding year his customers asked for them and preferred them to Lombards. There is only a small nurket for American apples in continental Europe, for the single reason that American apples are hardly known there. When the excessive crop of 1896 forced American apples into German markets they found friends, and in 1897 German buyers were anxiously inquiring for the fruit they could not get. The Canadian government, in seeking to stimulate the demand for Canadian apples in England, does so chiefly by making the fruit better known to Finglish consumers. 
4. Season.-There is an urgent demand for limited quantities of certain fruits out of their normal season. Hothouse strawberries and tomatoes usually bring disproportionately high prices. For the most part, however, the greatest volume of demand coincides with the market season of each fruit. Fameuse apples are wanted in November and December, and Northern Spy in February and March. Strawberries are wanted in strawberry season, while a month later most people prefer raspberries. The demand for certain fruits at certain seasons, however, is sometimes due to more recondite causes. Thus there is, in the eastern states, a demand for early plums and for late piums, while mid-season varieties are apt to go begging. This is because the few early plims are wanted for eating fresh, while the late ones are used for canning. During August the housewives are either at the seashore or on the back porch trying to keep cool. Nobody wants to stand over a hot store canning plums during dog days. But when vacation is over and the days are cooler the housewives' thoughts begin to turn to the winter supply of canned fruits, and then the lateripening Green Gages, Italian prunes, and Damsons come into strong demand.

5. Supply of other fruits. - When bananas are excessively plenty and cheap, fruit eaters hesitate to pay large prices for apples. When peaches are low in price they are canned in preference to high-priced plums. The price of plums, in fact, is apt to be determined by the supply of peaches. Thus the supply of one fruit affects the demand for others thronghont the list. 
All these factors must be kept in view by the fruit grower who is studying the price of his goods. It will be seen, however, that certain of these conditions are more within the control of the individual fruit grower than others. So far as his own goods are concerned, the price at which they will sell depends chiefly on quality, season, perishability, and storage. These factors he can determine for himself-at least to a large extent-and to them he will naturally give his principal attention.

\section{UTILIZATION OF WASTES}

Fruit growing is essentially a manufacturing business. The points in which the production of a fine grade of strawberries agree with the production of men's ready-made shirts are many, and an extensive comparison of the two lines of business might be made with profit, except that it would be too much of a digression to fit with the simple plan of this essay.

In most lines of manufacturing the saving of the wastes and the utilization of by-products are highly important parts of the business. Some manufacturers actually lose money on the main output, while paying good dividends out of the by-products. The packinghouse men say that they can lose money on every beef animal killed, and yet make money enough out of cowhides and the fertilizer tank to save themselves handsomely. A friend of mine who used to help Mr. Armour handle pork told me that they saved every jot and scrap of the hog except his dying squeal, and that they hoped presently to contract that to the government for use in fog-horns. 
Now nothing is more obvious than that the fruit grower meets with serious wastes. Sometimes a third part of his peacles are unsuitable for the narket, and apple growers occasionally throw out more apples than they put into the barrels. Any profit which might be wrung from these wastes would be especially acceptable.

Unfortunately it must be said that the utilization of fruit wastes has never proved conspicuously successful; and, furthermore, that, in the majority of instances where something has been done, the profit has not accrued chiefly to the man who grew the fruit. The causes which have contributed to this result will become more obvious, perhaps, in the course of the following discussion.

The principal ways of using waste or cull fruits are drying, canning, preserving, jelly making, manufacture of cider, vinegar, spirits, etc. A few words on each of these may suffice.

I. Drying and evaporating.-One of the best uses to which cull fruit can be put is to dry it or evaporate it. Formerly the home manufacture of dried apples, dried peaches, dried pumpkins, etc., was common in all the farming districts of the United States-at least, in the north-and home-dried fruit was to some extent an article of barter in the country stores. That day has passed. Home-dried apples and peaches went out with home-knit socks and home-made soap. There are still families who dry their own apples, just as there are some who still make soap and knit socks; but for the most part these have all been given up. The change 
has been the sane in all cases, and has resulted from the san1e causes. It is cheaper to buy soap than to make it, easier to get ready-made socks than to knit them, and equally easier to buy dried fruit than to dry it one's self. It is a question of division of labor. The man or the stock company that makes a

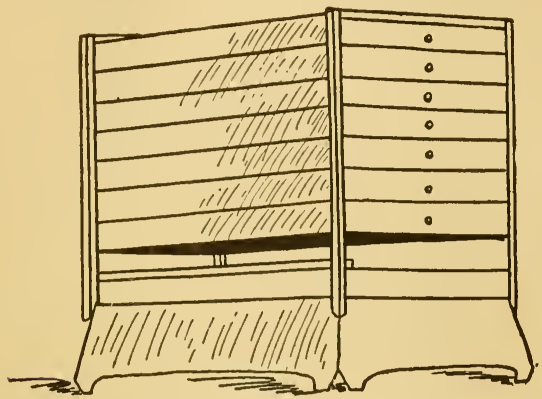

FIL. 4-SIMPLEST FORM OF EVAPORATOR. MADE TO SKT UPON THE KITCIIEN STOVE

business of drying fruit on a large scale can do the work to much greater advantage than the farmer or the farmer's wife. His product is more uniform, better in appearance, and perhaps also better in quality than the home-made article, while at the same time it can be sold at a much lower price.

Fruit drying and evaporating, therefore, has been almost wholly taken out of the fruit growers' hands, and has fallen under the management of specialists. Under ordinary circumstances the fruit grower has nothing to do with it except to deliver his peaches or 
his blackberries at the dry-house. As this book is written for the fruit grower we need not examine closely into the business of the fruit buyer, the cold storage manager, the transportation company, the evaporating house, or the outside speculator. We are concerned orly in the inome drying of fruit, and such drying is nearly obsolete. We may be sorry that it is so; but that does not change the fact, and it need not lead us aside from the present discussion.

All sorts of fruit can be dried or evaporated; so can many regetables. Apples, peaches, apricots, plums, blackberries, and raspberries, among the fruits, are especially good when well eraporated; and corn and pumpkins are most prized of the regetables.

Different varieties behave differently in drying, depending largely on texture and water content. These differences are particularly noticeable among apples. The general nature and range of these variations may be seen from the following table, giving the amount of dried fruit secured from the bushel of green fruit, and the approximate time required for drying:

Pounds to Hours required the bushel to evaporate

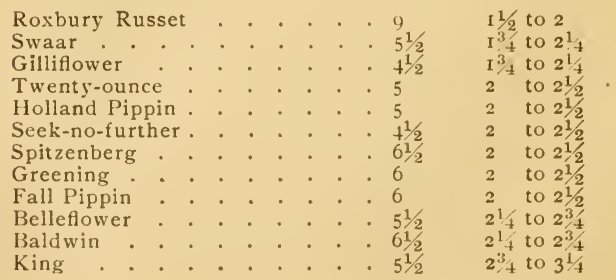




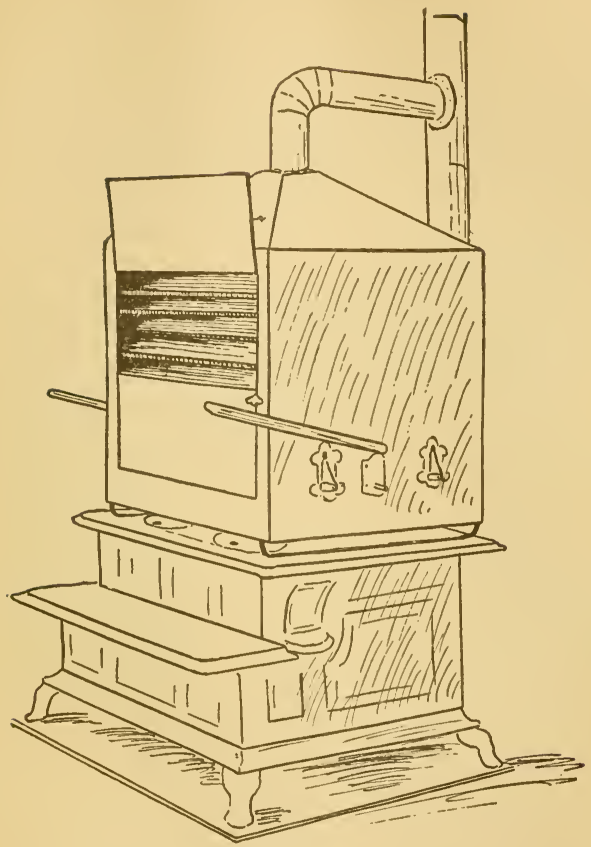

FIG. 5-A MORE ELABORATE COUK STUVE EVAPORATOR

From the above table it will be seen that it is better, when apples are to be dried, to assort them, drying the kinds that are most alike together.

Very simple evaporators can be bought for home use. The two shown in Figs. 4 and 5 are of this 
nature. Both are made to sit directly upon an ordinary cook stove or kitchen range, and to take their heat from that source. Such machines will dry from one to two bushels of green fruit a day. The capacities of the larger as well as of the smaller evaporators may be judged from the following figures, taken from the circular of the Vermont Farm Machine Co.:

Size.
Trays $\begin{gathered}\text { Capacity. } \\ \text { Inches }\end{gathered}$
Bushelsperduy
of green fiuit,

\begin{tabular}{|c|c|c|}
\hline & & \\
\hline No. & & \\
\hline $\begin{array}{l}\text { No. I } \\
\text { No. } 2\end{array}$ & & \\
\hline $\begin{array}{l}\text { No. } 2 \\
\text { No. } 3\end{array}$ & : & \\
\hline No. $31 \frac{1}{2}$ & & \\
\hline $\begin{array}{l}\text { No. } 4 \\
\text { No. } 5\end{array}$ & & \\
\hline
\end{tabular}

$20 \times 20$

$20 \times 24$

$22 \times 28$

$22 \times 31$

$22 \times 34$

$30 \times 34$

$30 \times 4^{8}$

$30 \times 54$ $\begin{array}{lll}1 & \text { to } & 2 \\ 2 & \text { to } & 3 \\ 3 & \text { to } & 4 \\ 6 & \text { to } & 8\end{array}$

12 to 16

I6 to 22

30 to 40

50 to 60

The prices of these machines range from \$15 for No. o to $\$ 175$ for the No. 5. These may be taken as representative of the prices charged by other manufacturers for similar apparatus.

The more elaborate machines are built on the same general principles as the smaller ones, except that they are provided with their own furnaces. Figure 6 shows a typical machine of the larger sort. This particular machine is rated to evaporate eighteen to twenty-five bushels of apples in twenty-four hours.

The general manipulation of the small evaporators is fairly simple, and they are not subject to accidents or serious difficulties. The following directions given by the nuanufacturers for the management of one of the smaller machines will apply to nearly all others,

\footnotetext{
* No furnace; used on kitchen store.
} 
and serve to show the general requirements of home evaporation :

"A moderately hot stove or range is all that is required as to heat. Keep all the plates or covers on the stove, and set the drier on the top. Each tray holds one and a half to two quarts of berries, cherries, etc.,

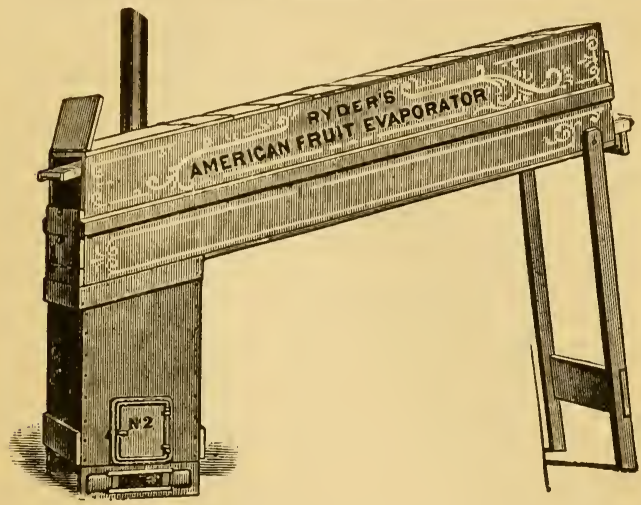

FIG. 6-A FULL-FLEDGED EVAPORATOR, HAVING ITS OWN FURNACE

without obstructing the hot air currents. Do not put more in a tray. Enter all trays with fresh fruit next to the stove, and change from lower to upper tracks, as other trays are entered, or as the drying progresses. When nearly done, the contents of a couple of trays may be put upon one, and fresh fruit entered and the operation continued indefinitely. Avoid putting the fruit on the trays so thick, either fresh or in doubling 
that partially dried, so as to obstruct the free circulation of the lot air currents through the machine, as this cliecks rapid work. Avoid scorching by moderate firing and close attention to frequent changing of the trays. If sulphur is to be used to prevent oxidation and secure a bright, handsome color for apples, pears, and peaches, simply drop a piece of brimstone about size of a medium bean on the store, close to or under the drier, and it will ignite and the fumes will be drawn upward through the machine and do the work. If you are operating in a close room or kitchen, and the smell is objectionable, you can fill the trays and put them in a box or barrel, with a cover on, and burn a little sulphur under them out in the open air, and then enter the trays in the machine. Procure a piece of mosquito-netting to throw over the machine when set aside, to guard against flies and other insects. This will not be in the way when on the stove. Do not cover top of machine with paper or a close cloth when in use, as it would stop the hot air currents going through it and prevent its working well, or at all."

The use of sulphur, as suggested above for the bleaching of the fruit, is frequently practiced. If carefully done, it gives excellent results. The fruit is made more attractive in appearance, it keeps better, and the flayor is unaffected. Excessive sulphuring, however, gives a less desirable color, and destroys the flavor of the fruit. In extreme cases the fruit is rendered totally nueatable, and even poisonous.

2. Canning.-The canning industry has enjoyed an unparalleled development in the United States during 
the last twenty-five years, and more particularly during the last decade. This will appear from certain figures given in the Appendix. The canning industry, proper, does not belong to the fruit grower, however. In certain cases the fruit grower plants, tends, and harvests fruit especially for the canning factory. In such cases the cannery is to be looked on as the fruit market, and is to be treated just the same as any other fruit market under similar conditions. In a good many instances, however, the canneries are located near large fruit markets (particularly about Baltimore), and depend to a considerable extent for their supply of fruit on the waste from the general market. They take the second-class and damaged consignments off the hands of the commission men. Thus an outlet is made for much waste fruit; but this outlet is not in the fruit grower's control.

Home canning, although highly to be recommended, seldom reaches such proportions as to affect the fruit market, even of the individual who does the canning. In home canning, moreover, the best fruit is apt to be selected, so that it is no longer a problem of utilizing wastes. The work, therefore, has little connection, direct or indirect, with the business of fruit marketing.

3. Other methods. - Waste apples are sometimes fed to stock, especially to cows, sheep, and hogs. It is still a question what their feeding value is, though it is certainly not very great. It is better to feed waste fruit to stock than to make no use of it at all. Other fruits besides apples are sometimes fed to stock, par- 
ticularly to pigs. It is said that pigs will eat anything but tomatoes and tobacco. Cider making, in some circumstances, offers a more or less profitable outlet for waste apples; and peaches occasionally develop into peach brandy. Perhaps the best brandy made in this country is distilled from apricots; but taken altogether, the production of brandy or other spirits from fruit in America-wine making excepted-is not important ellough to affect the general fruit business.

Wine making is a subject by itself, and can not be treated here. Cider manufacture, likewise, should be treated with wine making rather than with fruit marketing. 


\section{PART TWO}

\section{Picking}





\section{P I C K I N G}

The marketing of fruit really begins with the picking. In fact, a great many buyers go to the fields, bargain for the fruit on the trees, and attend to the picking, grading, and packing themselves. Even when the grower lolds his own fruit for a considerable time between picking and selling, his method of handling it in the market must all be foreseen at picking time, and the picking must be managed in a way to fit in with the general plan of marketing.

\section{$y$ I. TIME TO PICK}

The perishable fruits are picked for market some time before they are really ripe. The exact time can be determined only by experience. It will depend on the distance the fruit has to be shipped, on the shipping quality of the variety, and on other considerations. Strawberries are picked as soon as they color. Red raspberries are left till they begin to soften slightly. Black raspberries are picked as soon as they will part from the receptacle on which they grow. Blackberries and dewberries are usually picked as soon as they are erenly colored. Gooseberries are often, in fact usually, picked while yet quite green. Currants are allowed to color, but must be picked before they are ripe, especially if they are to be of any use in jelly making-the end to which they are oftenest destined. 
Grapes are picked when they are ready, and it takes a man of experience to tell when that is. In the northern states, however, they may be allowed to hang late on the vines. In some vineyards the later varieties are habitually left out several days after the frost has removed most of the leaves from the vines. Thus they get the late autumn sun, and ripen up with a sweetness and a perfection otherwise unattainable in the short northern season.

Peaches and apricots are picked as soon as they show the first traces of ripening. The well-trained picker tests each fruit by taking it between his thumb and fingers, and feeling of it with the ball of his thumb. The fruit is not squeezed nor bruised; but if it has the faintest feeling of mellowness its time has come, and the picker transfers it to his basket.

Cherries are picked just before they ripen, and the best test for ripeness is to eat a few. After one gets the standard fixed in his mind by this simple and effective test he can tell by the color of the fruit whether it is at the desired stage or not.

Plums will bear picking when decidedly green-at least, many plums will, the Japanese varieties in particular. If they are destined for a near-by market they can be allowed to get fairly ripe, and in nearly all cases they should be allowed to hang as long as possible, except when they are wanted for jelly making. Most of the Japanese plums and some others ripen very nicely after picking, and they may be kept for three or four weeks even in a moderately cool, dark place, and come out ripe, juicy, and fit. In extrene cases they can be kept considerably longer. Some of the native 
plums, like Wildgoose and Pottawattamie, are apt to break their skins when overripe, and additional precautions have to be observed to pick such varieties sufficiently green.

Pears are usually taken from the tree before they are ripe, and are stored in a moderately cool, dark place to ripen. They should not be piled up too deeply. For marketing it is probably best to pack them temporarily in boxes and baskets convenient for handling. In case they are to go to market soon they may even be packed directly into the permanent boxes or baskets, and these packages may be placed in the storage room. Aside from the Kieffers and the California fruit, the pear business is so small in this country that no satisfactory system of handling it has been worked out.

Apples are practically never allowed to ripen fully on the trees. Many early apples, especially from southern orchards, are sent to market before they are full grown and while the seeds are quite white. Summer and early fall apples are always sold considerably on the green side. Late keeping varieties do not really ripen, of course, till January or March, as the case may be, but they are ready to pick just about the time the frost begins to thin the foliage risibly on the trees. Certain varieties, Spy in particular, are left hanging late, even after the leaves have mostly fallen and until night frosts are decidedly sharp. Fameuse and apples of that type require to be picked relatively early. When they begin to fall from the trees picking time las come. The poorer specimens naturally fall earliest from trees of all varieties, and by watching 
the windfalls the orchardist can tell better than in any other way when the picking is beginning to be pressing.

\section{PICKING RECEPTACLES}

Strawberries are usually picked into the quart boxes in which they are shipped. In case they are to be sorted the quart cups may still be used for picking. Six or eight of these are held in a carrier, and a carrier is given to each picker. Raspberries, blackberries, gooseberries, currants, etc., are commonly handled in much the same way. Howerer, all such berries as are solid enough to bear handling and some pouring may be picked into any convenient basket, and are then transferred to the shipping packages at the sorting table or in the packing shed. Cherries, peaches, and plums are either picked directly into the shipping packages, or are put into convenient baskets and brought to the sorting table. Whether a man adopts the one plan or the other depends largely on the help he has in picking. If the fruit runs fairly even and the pickers are competent to do the grading, the two operations can usually be advantageously combined. In case the pickers can 110 t be trusted to grade and pack the fruit, it is evident that the pickers' packages must be delivered at a sorting table, where the fruit is graded and repacked.

Apples are always picked clean off the tree as the work goes on, except in case of summer apples, which should be harvested in successive pickings. Some pickers prefer to pick into a half-bushel basket, which should be lined with burlap or sacking to prevent bruising the fruit. Other pickers prefer to use a sack 
which is slung orer the shoulders. When baskets are used the bails are provided with stout bent iron hooks, something like a letter $\mathrm{S}$, except that the lower curl is closed about the basket handle to keep it from coming off. The upper crook is made large enough to go over an ordinary branch, and this allows the picker to hang his basket securely within his reach, while he works among the branches with both hands. Ropes or straps are usually provided for letting the baskets down from the trees and pulling them up again.

Some apple growers pour the fruit from the picking baskets directly upon the sorting table, packing the apples inmediately. Others put the fruit in piles or windrows on the ground to be handled later. Still others empty the fruit temporarily into barrels, which are hauled to the packing shed, where the grading and packing are done at convenience. Each man should adopt that method which best suits his circumstances. Aside from personal preference and local convenience, one way is just as good as the other.

\section{STEMS ON OR OFF}

Some fruits are to be picked with stems attached, others are taken without the stems. The reasons which make the one method or the other desirable in each case vary considerably. Cherries and plums are picked with the stens for two reasons: first, the removal of the stem allows the juice to escape, moistening the package, and allowing decay to begin; and, second, the stems help to pack the fruit safely into the basket or cup. The stems act like so much excelsior or other packing material, preventing the soft fruits 
from squeezing one against the other. Apples are picked with stems on largely for the sake of looks, but partly also because the removal of the stem may give a chance for decay to begin.

The following schedule shows which fruits are usually picked with stems on and those which are usually removed from the stem. There are some exceptions to this classification, but they are local and unimportant:

Picked with stems on

Strawberry

Gooseberry

Currant

Grape

Cherry
Plum

Pear

Apple

Quince

Persimmon
Picked with stems off Raspberry

Peach

Apricot

Blueberry

Juneberry

\section{CONVENIENCES AND INCONVENIENCES}

In all the European books on horticulture, and consequently in all the early American works, there are described various fruit pickers. These usually consist of long poles surmounted with some contrivance for pinching, twisting, or cutting off the fruit, and with a receptacle for catching it. Such things are merely curiosities on a practical modern fruit farm. There is no need to describe any of them here.

Picking shears are used in gathering grapes. The

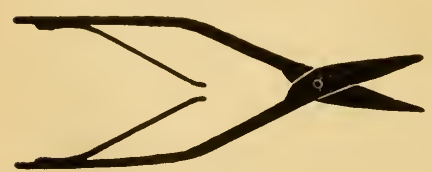

FIG. 7-PICKING SHEARS FOR GRAPES AND OTIIER FRUITS form most popular in this country is here illustrated. These can be bought of any dealer in horticultural supplies, and cost 
about 75 cents to $\$ 1.00$ at retail. Another pair of scissors, sonewhat different, and also shown in the illustration, is used for trimming the bunches of grapes when they are packed into the baskets for market.

Similar scissors can be advantageously employed in picking currants when they are to be nicely packed for a good market.

Occasionally one will find illustrated and described some so-called fruit-picking machines. For the most part these are even less worthy of description than the pole-pickers just referred to. They are usually some kind of a mechanical compromise between shaking the

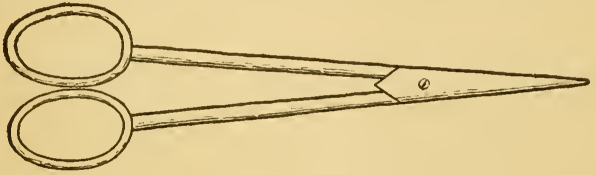

FIG. 8-SHEARS FOR TRIMMING FRUIT

fruit off the tree and picking it by hand. The typical fruit-picking machine consists of a considerable spread of canvas stretched on a frame and mounted on a wheelbarrow. The canvas is arranged somewhat in the form of a broad-flaring funnel. The apples, or pears, or plums are shaken onto this canvas and roll toward the center, where there is sometimes a hole through which they pass into a basket. The use of such machines is to be strongly deprecated. The only way to pick fruit is by hand. Certain exceptions should be made to this rule for fruit picked for canning factories and drying houses. Mechanical pickers may 


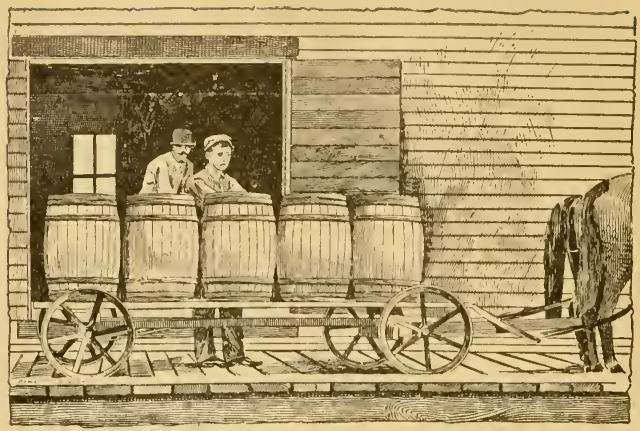

FIG. 9-A HAXDY HOME-MADE ORCHARD WAGON

be used to advantage in this work, but for the most part they have not been found very desirable.

It may be said in passing that it is still the practice in certain belated neighborhoods to gather fruit by shaking it off the trees and picking it up from the ground. There is no need of arguing against such a way of doing things. As soon as this fruit is taken to the open market the fruit buyer will furnish the most emphatic of arguments against it. Such fruit will not ship, will not keep, and will not sell. It is fit only for immediate home consumption or for sale in remote conntry markets where there is no business in fruits.

In picking tree fruits ladders of some sort are usually desirable or necessary. For trees of moderate size, such as most plums and peaches, a tall, light step-ladder is usually best and most convenient. This should be made with three legs, and not with four, as 
step-ladders are usually made. A three-legged ladder will stand almost anywhere it is put, whereas a fourlegged ladder will stand firmly, hardly anywhere in the field. For tall trees a light ladder made in the ordinary fashion is better than a step-ladder. This can be leaned against the branclies on the outside of the tree.

A low wagon with the trucks arranged to turn shortly is very desirable in handling all sorts of fruit in the field. It is valuable in the strawberry field and indispensable in the orchard. The low trucks advertised in agricultural papers are specially suited to this sort of work. A good substitute made from the trucks of an abandoned horse power is shown in Fig. 9. Another way of making up a liandy wagon for handling fruit is shorn in Fig. 10. Any handy man about the farm can readily arrange something of this sort. I liave seen an old-fashioned stone-boat used to great advantage in hauling in apple barrels from the orcliard.

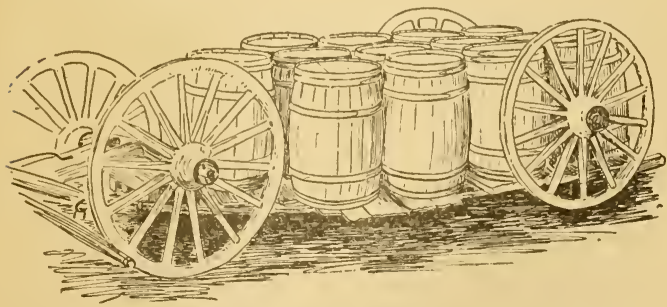

FIG. 1O-ORCHARD WAGON MALE UN ORDINARY WAGON TRUCKS 


\section{MANAGING PICKERS}

The management of pickers sometimes becomes a serious and complicated problem, particularly in handling such fruits as strawberries, cranberries, etc. In neighborhoods where fruit is grown extensively these methods have been pretty well worked out, and in many instances have become matters of custom. There are many schemes in use, but they may all be reduced to three general forms, somewhat as follows :

I. The day-book system. - In following this method, the poorest one of all, the proprietor, overseer, or foreman merely keeps a memorandum in his day-book, showing what each picker has done. Each picker's name is written at the top of the page, and the successive days' pickings are entered below. A record then takes some such simple form as this :

SARAH FORBES

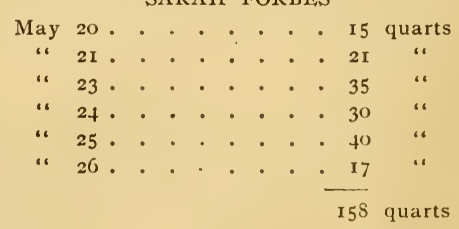

Where less than a clozen pickers are employed, where the same pickers return day after day, and where payment is made as often as once a week, this system may be satisfactory. Pickers are always prone to be dissatisfied with the account kept by the foreman, however, so that some system which throws the responsibility for errors more upon the picker himself, 
while at the same time protecting the employer, is generally preferable.

2. The check system.-Following this method the foreman issues a clieck to each picker for the number of quarts, baskets, or other packages picked. The check is exchanged for the baskets, as soon as they are picked, at the moment when they are delivered to the foreman.

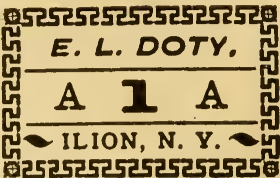
This check is commonly printed essentially in the forn show11 in Fig. I I, winch was engraved from a picker's check used on a New York strawberry farm. The figure shows the number of quarts picked, and the foreman has tickets bearing various numbers, such as are likely to be needed. On pay day these checks are delivered by the picker and redeemed by the employer.

3. The punch-card system.-This is probably, all things considered, the best method in general use.

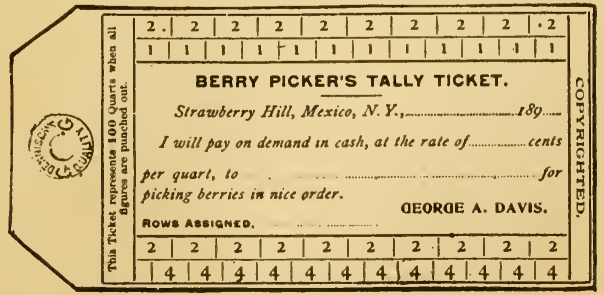

I.IG, I2-DAVIS' PUNCH CARD 
Each picker is provided with a printed punch card, which is usually either written with the picker's name or punched with his number. Along the margins of the card various numbers are printed, and these are punched with a conductor's punch by the foreman as the baskets are delivered. Each picker retains his own punch card all the while, and is solely responsible

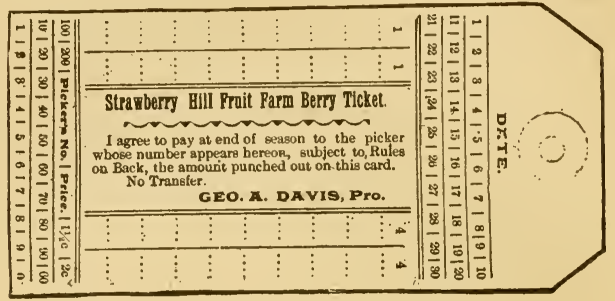

HIG. I3-ANOTHER FORM OF PUNCH CAKD USED BY MR. DAVIS

for it. In some fields it is customary to issue a fresh card every morning. In other places the cards and the work are of such a nature that the same card will record the pickings for sereral days or for a whole week.

Without presuming to offer any new scheme, we may point out that none of these systems is perfect. If some device could be arranged whereby the foreman and the picker could quickly secure duplicate records of each parcel of fruit delivered it would come nearer the icleal system. Something like a railway train conductor's cash-fare ticket might answer. This would 
require to be furnished with three sets of numbers: one to give the picker's number, one for the date, and one for the number of quarts or baskets delivered. This would be somewhat complicated, since it would require three punchings and the remoral of the picker's duplicate slip for each delivery of packages. Still this system might be adapted to suit certain circumstances very nicely.

It ought to be remarked that frequent pay days

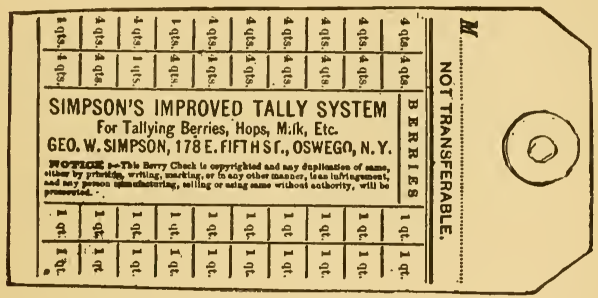

FIG. If-SIMPSON'S PUNCH CARD

are very desirable, no matter what system of accounting is followed. The opportunities for losing tickets or for making various mistakes are so numerous that every occasion should be taken for preventing such difficulties. With pay day coming as often as once a week mistakes can be more easily discovered and rectified. If payment can be made at the end of every day it is still better. The memory of the foreman and of the picker, taken jointly, is worth something then.

Apple pickers usually work by the day, and peach and plum pickers often do. In such circumstances 
the foreman merely keeps account of the time. Apples are sometimes picked by the barrel, however, and in that case it is best simply to furnish each picker with a piece of chalk, directing him to mark his number on each barrel picked. When the barrels are hauled into the packing or storage shed the foreman's account can then be made up from the numbers. When apples or pears are picked by the bushel, by the basket, or in any similar way, the record may best be kept by one of the systems described above.

In the management of pickers it will be found of the utmost importance to assign each one to a given row or tree, and require him to pick it clean. All sorts of serious difficulties arise if the least neglect of this precaution is allowed. 


\section{PART THREE}

\section{Grading and Packing}





\section{GRADING AND PACKING}

It would be hard to over-emphasize the importance of grading fruit for market. Grading is something which can not be overdone. The more rigid the grading the better it pays. Careless and unthoughtful fruit men often think that they can not afford to take great pains in sorting, except they secure thereby an extra select grade of fruit for which they can command a fancy price. Because apples were abundant and low in price in I 896 many growers thought they could not afford to sort them carefully; but in every case events proved that the man who most rigidly graded his apples was the only one who made anything from his sales.

I have heard Mr. J. H. Hale give lis experience in handling muskmelons. He had some growing in his Georgia peach orchards when they were a drug in the northern markets; yet by throwing away three-quarters of the entire crop he was able to realize a handsome profit out of the other one-fourth, consisting only of fancy melons. A shrewd student of mine who earned his way through college made a part of his money by strawberry growing. He sold his berries at home in a little country village. When strawberries were selling at twelve and a half cents a quart he 
sorted lis product into two grades, and sold the first grade-something over lialf the crop-at twenty cents a quart, and the second grade at ten cents. This left him a handsome margin for his sorting.

\section{I, THE PRACTICE OF GRADING}

Most fruit is practically unsaleable without sorting, and the better it is sorted the better it sells.

Frequently the sorting of fruit consists merely in removing unmarketable specimens. It is seldom practicable to divide a picking of strawberries, berry by berry, into two grades, as my student friend did it, and I never knew of blackberries or gooseberries being picked over by hand in that way. Bad specimens should always be removed, however, and the best way to do this is not to pick them.

Grapes are generally sorted (at least, for the better class of trade), the work being done in the packing shed when the fruit is put into the baskets. A pair of slim scissors, made for the purpose, is used, and all bad or broken berries are trimmed out.

Most fruits which are handled on a large scale, such as apples, pears, peaches, oranges, etc., are subjected to a more complicated process of grading. Two or three, or even four or five, grades are made from the crop from the same trees. It is customary to divide apples, for example, into first grade (often called "selects"), second grade (usually called "firsts," "XX," or even "XXX,"), and culls (which in years of scarcity go to market as "seconds"). 


\section{WHAT IS FIRST-GRADE FRUIT?}

Occasionally some one gets up an argument over what should constitute a first-grade apple, peach, or pear; and from time to time some well-meaning committee of some horticultural society seeks to define specimens of the first, second, and third grade. In the market sense, however, such a thing as a first-grade apple or peach does not exist. The simple reason is that 10 marketman buys a single apple or peach. In the fruit market fruit is handled only in the original packages. First-grade apples means a package of apples of the first quality; but a single apple which would be properly placed in one package of first-class apples might be below standard in another package of first-class apples. It would be possible to take two packages of first-grade apples, and simply by mixing them to make two packages of second-grade apples. In the same way it is possible, by careful grading, sometimes to make two barrels of first-grade apples out of two barrels of seconds. I am assured that many commission men make good profits out of the careless customers by doing just such things as these.

In other words, the terms " select," " first grade," "'second grade," etc., are entirely relative. They do not refer to any absolute qualities of size, form, or color. 'The National Apple Shippers' Association, however, has adopted a definition for the different grades.* Even this definition, it will be seen, is largely

* The rules for the grading of apples, as adopted by the National Apple Shippers' Association in a resolution passed August 3, 1900, are as follows:

"The standard for size for No. $x$ apples shall not be less than $2 \frac{1}{2}$ inches 
relative, and furnishes only an apparent contradiction of the generalization here set forth.

Three considerations, all more or less relative, chiefly govern the grading of fruit. These are (1) uniformity, (2) freedom from injury, (3) agreement with the mark. First-grade fruit must be uniform in size, color, and sliape. Uniformity in size is far more important than mere bigness-in fact, overgrown fruits are rarely in demand. This is why an apple which would be adnitted to the first grade in one lot would have to go with the second grade in another lot. This requirement of uniformity is the one cliefly to be considered in handling fruit. Until one learns to disregard the individual specimen and look at the package as a whole he is not competent to grade fruit.

Fruit of the first grade (or "selects") must also be free from bruises, insect injuries, and all other defects. Many persons imagine this to be the principal consideration in sorting; but, important as it is, it stands second always to uniformity. Where grading is very careful all injured specimens are excluded from the second grade as well as from the first. For

in diameter, and shall include such varieties as the Ben Davis, Willow Twig, Baldwin, Greening, and other varieties kindred in size. The standard for such varieties as Romanite, Russet, Winesap, Jonathan, Missouri Pippin, and other varieties kindred in size sliall not be less than $2 \frac{1}{4}$ inches. And, further, No. I apples shall be at tine of packing practically free from the action of worms, defacement of surface, or breaking of skin; shall be hand-picked from the tree, a bright and normal color, and shapely form.

"No. 2 apples sliall be hand-picked from the tree; shall not be smaller than $2 \frac{1}{4}$ inches in dianeter. The skin must not be broken or the apple bruised. This grade must be faced and packed with as much care as No. $I$ fruit." 
instance, some successful apple shippers make four grades, about as follows:

I. "Selects."-Extra fine specimens only; uniform in size, color, and form, and without blemish.

2. "Firsts."-Good fruits, but not so fine as "selects"; uniform in size, color and form, and practically free from scab, insect injury, or other defect.

3. "Seconds." - Mostly good, eatable fruit, fairly uniform, and not conspicuously marked by insect, fungus, or other damage.

4. "Culls." - These usually go to the cider-mill, the dry-house, or the cattle-pen.

First-grade fruit, furthermore, must be true to the mark on the package. If the mark specifies Elberta the peaches inside must be Elbertas, and must look like Elbertas. They must conform to the accepted type of the variety named. Burbank and Chabot plums may be of the same size, and they may look very much alike, but they must not be mixed together; and a basket of Burbanks must not be labeled Chabot.

\section{THE DESIGNATION OF GRADES}

The terms by which the various grades of fruit are designated are not well fixed nor generally understood; in fact, the very opposite is the case. Mr. A. W. Grindley, agent of the Canadian government in Liverpool, tells me that the marks which appear on fruit barrels shipped there from Canada and the United States are of the most diverse and confusing nature. First-quality fruit may be marked simply " $\mathrm{XX}$," or it may be "XXX," or "XXXX," or even more; 
and Mr. Grindley assures me that he saw one consignment of Canadian apples arrive on the Liverpool docks marked with a row of eighteen $X$ 's-and they weren't very good apples either!

It is customary to call the first grade of all sorts of fruit " select," " extra," or " extra select," or to brand it with as many $X$ 's as the shipper sees fit. There is even less agreement in the use of the $X$ 's, however, than in the use of the terms just mentioned. The next grade below " select," " extra," or " extra select," is usually called " firsts, " " A r, " or is designated by one or two X's less than the " selects " of the same shipper. The third-grade fruit may go into the market 111arked " seconds," but it is more likely to be marked " $\mathrm{X}$ " or " $\mathrm{XX}$ "; ; if the second grade is marked " A I " the third grade is simply " 1 ."

Some attempt has recently been made in Canada to secure a uniform system of grading and marking, especially: of fruit for export. The system of marks proposed by the Ontario Fruit Growers' Association is as follows: $*$

( I) X A No. I. Sound apples or pears of uniformly large size and high color for the variety named, of normal form; at least ninety per cent free from worm holes, scabs, or other defects.

(2) A No. I. Sound apples or pears of nearly uniform size and good color for the variety named, of normal form; at least ninety per cent free from worm holes, scabs, or other defects.

(3) No. I. Sound apples or pears of fairly uni-

* The law recently passed by the Canadian Parliament covering this point is given in full in the Appendix. 
form size; at least eighty per cent free from worm holes, scabs, or other defects.

(4) No. 2. Apples or pears that are disqualified from being classed under any of the aforementioned grades, but which are useful for culinary purposes, and not less than two inches in diameter.

\section{SORTING TABLES}

For grading fruits some kind of a sorting table is usually best. The size and character of this sorting

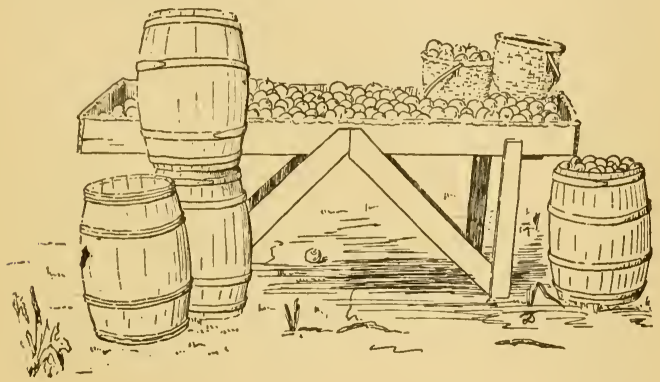

FIG. I5-APPLE SORTING TABLE.

table are determined by the kind and quantity of fruit to be handled, and somewinat by other and more local circumstances. The larger the package to be filled the larger the table should be. As a general rule, subject to some exceptions, it may be said that the sorting table should be large enough to hold at once, and to display within reach of the man who grades, enough fruit to fill three packages. An apple sorting table, for instance, should be roomy enough so that 
three barrels of apples can be spread out on it at once. Under no circumstances should it hold less than two barrels. No man can make eren grades with less fruit before him, especially when there is much variation in the stock handled. For sorting grapes, peaches, and plums a considerably smaller table will do. If only one person is employed at this part of the work, any small table may be used with a strip two to four inches high ruming round to keep the fruit from rolling off. If a large quantity of fruit is to be handled, a long ruming table is demanded. This may conveniently slope slightly toward the sorters. The sorters may stand or be seated in a row at one side of this running table, while the fruit and packages are delivered to them from the other side.

The ingenuity of the manager must be chiefly depended on to make a sorting table to suit the particular circumstances of any time and place; but the fact must not be overlooked that a good sorting table, properly adapted to the work in hand, is one of the most efficient helps to economical and successful fruit handling.

\section{GOOD JUDGMENT IN GRADING}

The work of grading naturally requires good judgment based on long experience. The man who grades the fruit occupies the most responsible position in the organization of the fruit farm, next to the manager himself. On fruit plantations of moderate size the manager often does the grading with his own hands. For the sake of the supreme requirement-uniformity -it is evidently desirable also that the work of grading 
shall come as nearly as possible under the eye of a single person. If one man can handle all the fruit the sorting should be entrusted to him alone, and he sliould be as nearly an expert as can be found. Under any circumstances as few graders should be employed as possible. It is especially undesirable to have a picking gang of five or six persons who are always "trading jobs" with one another.

When large quantities of fruit are to be handled into small packages girls are often employed. This is done for cheapness' sake, and may or may not result in poorer grading. Girls are usually hired to sort and pack grapes, and Mr. Hale employs girls for packing peaches. In all such cases, of course, the packing is done under the immediate supervision of an experienced foreman, who sees that the grading is properly attended to.

Grading by machinery has been resorted to in some cases, especially with apples and peaches, and mechanical graders are occasionally offered for sale. They are not to be recommended, however. Grading is chiefly a matter of judgment, and a machine has no judgment.

\section{FILIING THE PACKAGE}

The manner in which the fruit is put into the package is a matter of some consequence. The perfect arrangement of California fruits into the packages does much to make the goods attractive and to expedite sales. Even strawberry and blackberry boxes may be advantageously faced if a good grade of fruit is going to a good market.

Apples in this country are habitually faced at 
both ends of the barrel. The empty barrel is placed head down in front of the packer. A layer of good specimens is placed in concentric rings, stem end down, on this reversed head, and a second faced layer is placed on top of this. Some careful packers face three layers, but this is hardly necessary. After the two facing layers are in position, the barrel is filled nearly full by pouring in the sorted fruit from baskets, or by letting the apples roll over a padded curtain or sleeve from the sorting table. Finally two more layers of good specimens are laid on the top by hand. These are placed in concentric rings and faced toward the opposite head (in this case the bottom) of the barrel. The last layer should protrude about two or three inches, this amount being taken up by the pressure when the head is put on.

The head is then put on top of the apples either with or without a paper heading inside (see under "Fruit Package," Part IV.), and is forced down into place with a suitable press. This pressure is so great that the apples on the face are considerably bruised at times; but this seldom results in any loss, whereas insufficient pressure is often the source of serious damage to the fruit during shipment. The apples are apt to shrink measurably, either by transpiration of water or by incipient decay, and this shrinkage immediately leaves the fruit loose in the barrel. If there is the slightest looseness during shipment, or when the barrels are handled, the apples shake about in the barrel, and are quickly bruised to their permanent injury--sometimes till they are totally spoiled for use. 
Various barrel presses are in use for bringing the heads down into the chimes. The best and most popular form is undoubtedly the lever press shown in Fig. 16. A screw press (Fig. 17) is sometimes used, but is awkward and undesirable.

Pears are handled in pretty much the same way as apples are, except that they are not so often packed in barrels. When they go into barrels, however, the

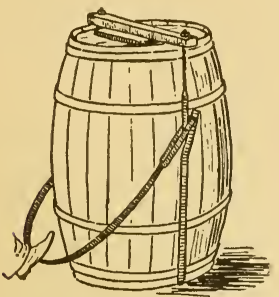

FIG. I6-ORDINARY LEVER PRESS FOR APPLE BARREL

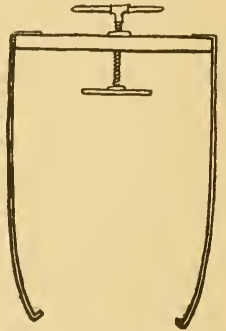

FIG. I7-SCREW PRESS FOR BARRELS

treatment is just the same as for apples, and when they go into boxes it is not much different. The use of boxes will be discussed further in the next chapter.

The best peaches are packed one by one into baskets, and the top layers are carefully faced, the apex of each fruit being laid obliquely upward. The same order of packing is followed, whether the peaches are wrapped or not. Peaches of medium or inferior quality are not handled a fruit at a time. Especially in Delaware and Maryland, where the deep baskets are used, the fruit is picked or poured into the basket, only 
the top layer or two being faced. Sometimes even this small attempt at facing is omitted.

Large and fancy plums are usually sold at the retail fruit stands in small quantities for eating out of hand. They are therefore packed in small boxes or baskets, and may or may not be wrapped. In either case they are faced. First quality plums not intended for the limited trade of the fancy fruit stands are packed into baskets, the top layer being sometimes faced. If the plums are large and attractive in appearance the facing is especially desirable. Small and dull colored plums gain little by being faced.

Most other fruits of the temperate regions, when sent to the market in the fresh state, are not packed according to any recognized system. Each shipper follows his own ideas or the demands of his own market. This statement, however, refers only to methods of packing. The style of package is more a matter of prescription, and is more generally established by custom. We shall proceed to this important subject with the next chapter. 


\section{PAR T FOUR}

The Fruit Package 



\section{THE FRUIT PACKAGE}

If there is one thing more than any other peculiar to the American fruit business, it is the American fruit package. Growers and shippers seldom realize this fast, and almost never grasp the full significance of it.

\section{THE AMERICAN FRUIT PACKAGE}

The characteristics of the American fruit package are cheapness, neatness, lightness, and uniformity. The packages must be cheap, because they are nearly always given away with the contents. The use of the gift package is elsewhere pointed out to be peculiar to the American trade. The American package is the neatest and most alluring that can be derised, for its attractiveness is largely depended on to sell the fruit. It is light and easily handled, a quality required when fruit is shipped in large quantities or when the packages themselves are manufactured and shipped by thousands. The American package is the only one which lays any claim to uniformity, and this claim is asserted with some reason. There are still many "short" barrels in the apple trade, and there is much complaint, partly legitimate, of false bottoms in strawberry boxes, and the "five-pound" grape basket sometimes holds a scant four pounds of fruit; yet after allowing for all the fully understood short packages, and for all intentional fraud, it is still true that 
14 FRUIT HARVESTING, STORING, MARKETING

the American fruit packages are uniform to a most remarkable degree.

There is much still to be done in securing honest uniformity of package, and the laws which have been passed in a few states $*$ are efforts in the right direction. For the most part, however, the conditions in the fruit market must be depended on to secure proper packing in honest packages. The commission man's returns are more influential with the average fruit grower than the laws of the state. Legislation in these matters is depended on in Canada to a much greater extent than in the United States. Whether it is any more effective toward the ends sought may be fairly doubted.

There are still many different kinds of packages in the American trade, a majority of which will be suppressed, perhaps, in the future evolution of our fruit industries. Those fruits which are most largely grown and shipped have the fewest styles of packages. Strawberries always come in quart boxes, crated. Apples practically always come in barrels. There are, thus, a number of recognized standard packages, the most important of which are as follows: The apple barrel, the strawberry box, the grape basket, the Delaware peach basket, and the Michigan peach basket.

\section{THE APPLE BARREL,}

The standard apple barrel in the United States is practically the same as the ordinary flour barrel. In fact, emptied flour barrels are extensively used for packing apples. The apple barrel specified by the

* See Appendix. 
American Apple Shippers' Association has the following dimensions: Staves, $281 / 2$ inclies; head, $171 / 4$ inches; circumference in the middle, 64 inches. This barrel holds one hundred quarts, and is known as the "Iooquart barrel."

In Nova Scotia, where the apple growers are, to some extent, a law unto themselves, a slightly different barrel is used. The regulation dimensions are: Head, $17 \frac{1}{2}$ inches; bilge, 19 inches; stave, 29 inches. This gives a long barrel with a comparatively straight stave. When such a barrel is placed on its side it rests on the hoops and lies much more securely than the barrel of greater relative bilge. This is a very important matter in shipping apples by steamer, as Canadian apples are largely shipped to Europe. A part of Nova Scotia's considerable success in the exportation of apples is due to the use of this barrel.

Apple barrels are seldom bought ready built, except when empty flour barrels are used. The usual practice is to buy the staves, heads, and hoops at the sawmills, and to have the barrels put together at a local cooper shop. Such a shop is usually to be found in every apple growing neighborhood doing business for several small growers. Large producers of apples commonly have their own coopering rooms. Here they make up their own barrels during rainy days, or else they have some itinerant cooper to come in and make them up when needed.

The cost of apple barrels varies from \$15 to \$30 the hundred. For the last two years it has been about $\$ 25$ a hundred for good barrels. The cost is about the 
same whether flour barrels are bought or stock secured in the knock-down and put up by a cooper.

As has already been remarked, empty flour barrels are often used for packing apples. When strong, fresh barrels are chosen and thoroughly cleaned there is little or no objection to their use; but the least carelessness in this respect brings loss to the grower. When a buyer sees an old, stained, battered barrel he immediately rates the contents as poor, and refuses to
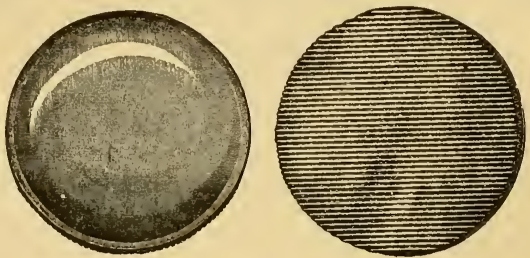

FIG. I8-CARDBOARD BARREL HEAD LININGS

pay anything but the minimum price. When a barrel is opened and the apples are found half covered with the flour which was needlessly left clinging in the chimes, the lot is once more relegated to the second class. It is the simplest matter in the world to lose twice the price of a good barrel in this way. Good fruit deserves a good package, and poor fruit will not sell without it.

Certain small accessories are sometimes used with the apple barrel, though there is no uniformity in this matter. The most usual device is a paper reinforcement for the head, which protects the fruit somewhat from bruising when the head is pressed in and which 
takes up a certain amount of moisture to the advantage of the fruit. These false heads are sometimes made of old newspapers deftly folded. More often they are bought ready cut from heavy cardboard. A patented cushion head of corrugated paper, shown in Fig. I8, is manufactured by Frank B. Read, of New York and Philadelphia.

\section{BERRY PACKAGES}

Strawberries are always shipped in small boxes or cups, holding usually one quart each, but occasionally

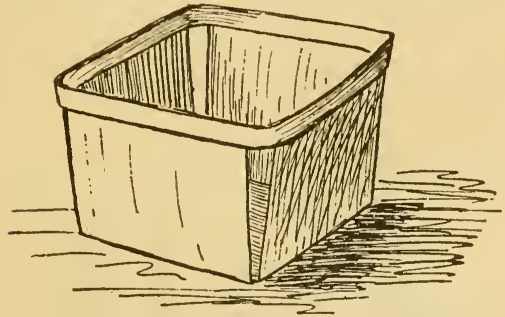

FIG. I9-THE USUAL BERRY BASKET

only a pint. (In Europe, I am told, berries are often sent to market in tubs, kegs, and such like utensils. It makes an American laugh just to hear of it.) These cups or boxes are made in various forms, some of the more usual being shown herewith-Figs. I9 and 20. There is a general tendency toward the square box. The oblong, broken-cornered box is going rapidly out of fashion, and properly so. These boxes are usually made of wood veneer, but occasion- 
ally of paper. The paper box may become popular in the future, but it seems lardly probable.

The quart boxes are always shipped in crates, each crate holding twelve, sixteen, twenty-four, thirty-six,

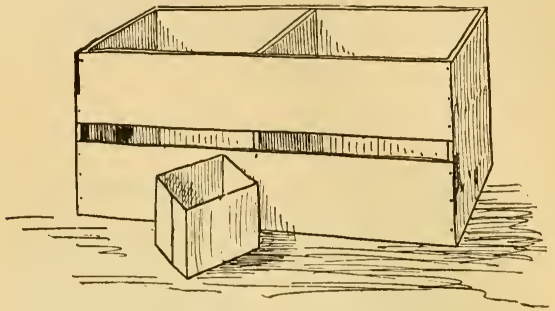

FIG. 2O-SQUARE BERRY BASKET AND CRATE

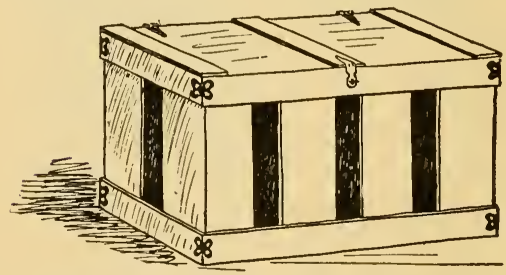

FIG. 2I-BERRY CRATE-COMMON FOKM

or forty-eight quart boxes. Larger sizes seem to be comparatively more popular southward, especially in the Baltimore market, while comparatively smaller sizes are preferred northward. The thirty-two quart crate is probably most common, and the sixteen, twenty-four, and thirty-two quart crates are vastly in 
the majority. Larger or smaller sizes are the exception.

These crates are strongly made of wood, sawed in strips as light as is compatible with strength, and firmly nailed togetler. Sometimes they are given metal bindings at the corners. The crates are frequently returned to the grower when shipped within a distance where express companies return empties free. Otherwise they become gift packages, just as grape baskets or plum boxes are.

Raspberries, blackberries, dewberries (commonly sold as blackberries), gooseberries, and currants are nearly always sold in the same boxes and crates used for strawberries.

\section{THE GRAPE BASKET}

Two standard packages are in use for grapes, the only difference between them being in point of size. One is the fivepound basket, the other the tenpound basket. The ten - pound baskets usually hold only a trifle over eight pounds of fruit, and the five-pound baskets usually only a

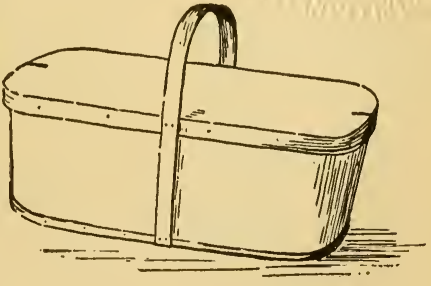

FIG. 22-THE GRAPE BASKET little over four pounds; but as this is rather commonly understood, no one is greatly deceived. Besides, grapes are always retailed by the basket, not by the pound. 
The grape basket is made of thin wood veneer, with a light wood binding at top and bottom. It has a light wooden cover which is fastened on with a special staple. It has a bail either of wood or of wire. There are comparatively few variations in the form of this package.

The grape basket is frequently used for other fruits, particularly for plums. It is sometimes used for tomatoes, occasionally for pears, infrequently for persimmons, gooseberries, and currants, and I have even seen it used for fancy baking potatoes. It is the most generally convenient and handy package ever devised, and it is not at all strange that it should be put to a variety of uses.

\section{PEACH PACKAGES}

I can remember when peaches were commonly shipped in slat crates, the usual form being made with

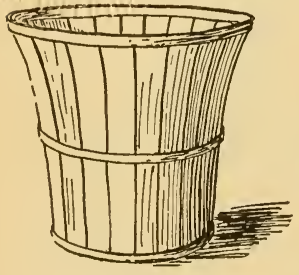

FIG. 23-DELAWARE PEACH BASKET two compartments, each compartment holding approximately a peck of fruit. This package has now been almost entirely abandoned for peaches, though a similar crate is still in use for a variety of the lesser fruits, being more commonly filled with pears, apples, peaches, plums, quinces, or tomatoes.

But the peach business has taken up two strangely different baskets, the Delaware basket and the Michigan or Georgia basket. Recently a third style of 
package, the "six-basket carrier," has been coming into vogue.

The Delaware basket is in the form of the inverted frustum of a cone. It is made of wood splints, and sometimes has a splint cover. At other times the package is covered simply with mosquito netting or other cloth. This is more often the case when this basket is used for sweet potatoes, Irish potatoes, spinach, and other vegetables, as it frequently is. The Delaware basket comes in various sizes, one bushel, one-third bushel, and half bushel, with various "short" sizes between. In New Jersey

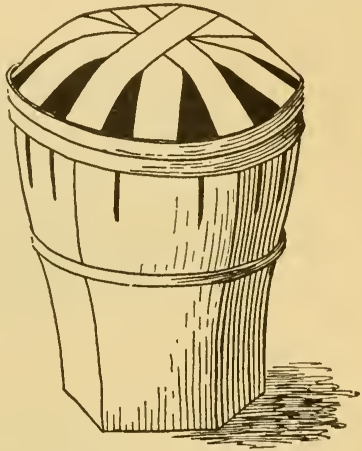

FIG. 24-WIDE SLAT DELAWARE BASKET WITH SPLINT COVER the size of this package has been the subject of legislation.*

The splint star cover, as shown in Fig. 24, is sometimes used for this basket, but not commonly, in shipping peaches from Maryland, Delaware, and New Jersey.

The Michigan peach basket, which is essentialiy the same as the Georgia peach basket, is shown in Fig. 25. This is much like the standard grape basket, the chief difference being in the matter of the cover.

* See A ppendix. 
The peach basket cover is macle of slats nailed to curved supports at either end. This package varies somewhat in size, but the ustual sizes are pecks and fifth-bushels.

The third and newest form of peach package is the

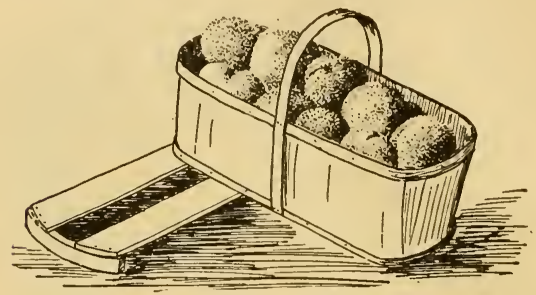

FIG. 25-MICHIGAN PEACH BASKEF

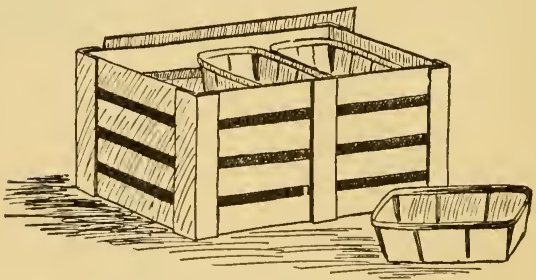

FIG. 26-SIX-BASKET CARRIER

six-basket carrier. This carrier is merely a neat slat crate, of much the same form as the strawberry crate, and just large enough to hold the six small wood veneer baskets. These baskets hold approximately a half peck, so that the six-basket carrier landles about 
three-fourths of a bushel of fruit. The baskets fit into the carrier in two layers, one above and one below, with a thin slat false staging between to prevent the bruising of the lower tier. This makes an extremely neat and convenient package, and one which has been

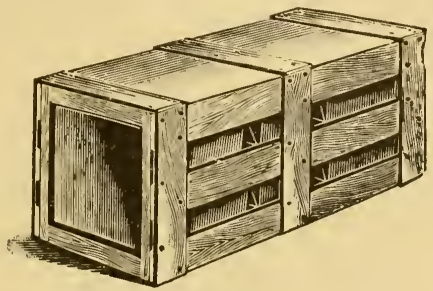

FIG. 27-SIX-BASKET CARRIER, CHEAPER FORM

used with considerable success by shippers of fancy peaches. It is well stited to good grades of other fruits, such as plums, apricots, persimmons, hothouse tomatoes, etc. During the present season, I9o I, Mr. J. H. Hale has been using this same carrier with nine shallower baskets for shipping plums. It is naturally a package for select grades only, and is not to be reconmended for cheap stock.

\section{APPLES IN BOXES}

There is a strong tendency among progressive fruit growers at the present time to offer fancy apples in packages smaller and more attractive than the standard apple barrel. Baskets have sometimes been employed, but the general effort seems to reach toward some kind of box. 
The use of some such small, convenient, and attractive package for fancy apples is amply justified on theoretical grounds, and its adoption is only a question of time and of evolution in the trade. Already some sellers have been successful with small packages, and the more unsatisfactory experience of other shippers is usually fairly attributable to the conservatism of the

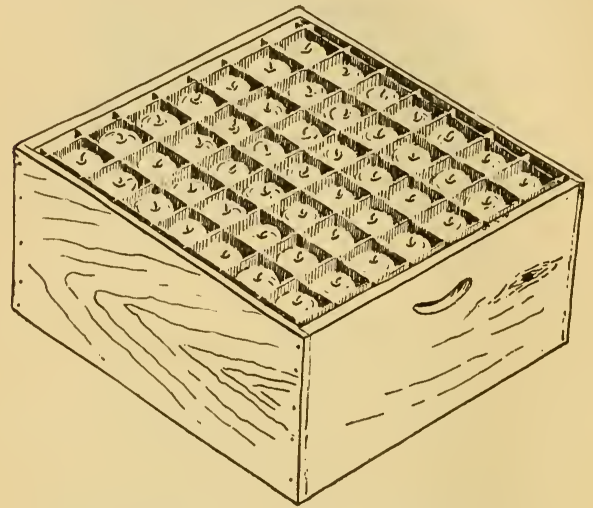

FIG. 28-MR. SHEPHERD'S APPLE BOX

market. It takes a while for any new thing to become established, however meritorious it may be. Commission men generally have held out against the small package for apples, and their influence is naturally great.

One of the best, and certainly the most successful, apple box of which I know is the one used by Mr. R. W. Shepherd, of Montreal, for the fancy export 
trade. This box, shown in Fig. 28, is solidly built of wood in sizes computed to fit the apples. Each case holds from one hundred and ninety-six to two hundred and twenty-four apples, according to size of the fruit. Inside the box pasteboard partitions are used, precisely like those commonly found in egg cases, except, of course, that the pasteboard compartments are larger. These cases cost about forty cents each in

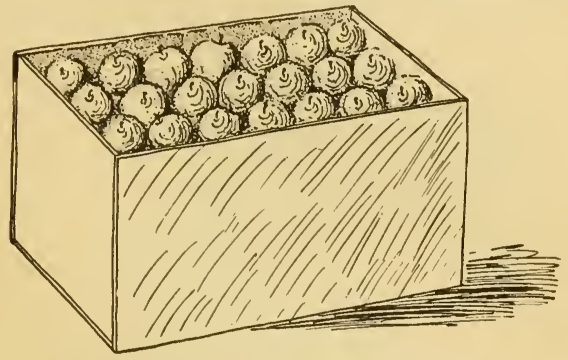

FIG. 29-MR. WOOLVERTON'S APPLE BOX

quantity, and weigh sixty to seventy-five pounds each when filled. Mr. Shepherd uses these exclusively for his fancy export trade, and ships in them only the best fruit of a few special varieties, chiefly Fameuse, McIntosh, and St. Lawrence, and these only on order.

Another apple box, used by Mr. L. Woolverton, of Grimsby, Ontario, is shown in Fig. 29. This box holds a bushel, and will carry one hundred and twentyeight apples of approximately two and one-half inches diameter. Each specimen is wrapped in paper. Mr. 
Woolverton, as the result of ten years' experience, finds this box useful for the exportation of fancy apples, but does not believe it can be profitably adopted for common stock or for local market.

\section{OTHER FRUITS AND PACKAGES}

Various other packages are in use for one and another purpose. One of the most convenient and useful is the round splint basket with handles at

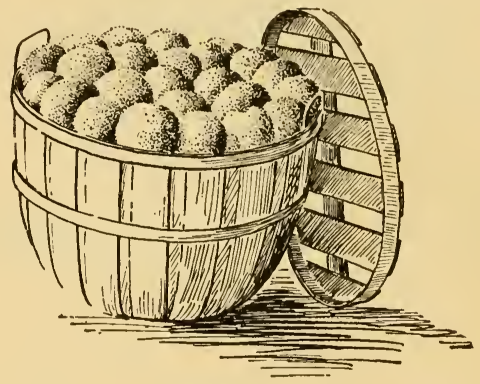

FIG. 3O-SILINT BUSHEL BASKET

the sides, as shown in Fig. 30. This basket comes principally in two sizes, bushel and half bushel. The half bushel is sometimes used for peaches, quinces, or tomatoes, and perhaps also for apples. The larger size is used for apples, potatoes, etc. This is a handy basket for farm use and may be adapted to various fruits in special circumstances. It is not recognized as standard for anything, however. 
The slat crate, Fig. 3I, has already been referred to as formerly much used for peaches. It is still used, mainly by small shippers, for many fruits, such as peaches, pears, apples, quinces, and more often for

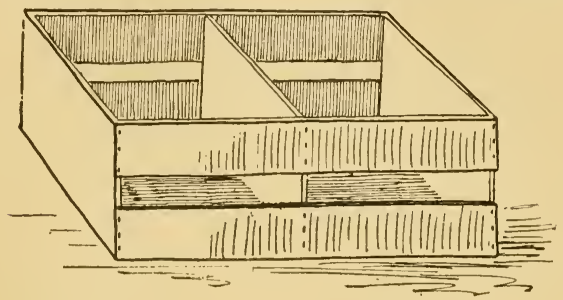

FIG. 3I-SLAT CRATE USED FOR VAKIUUS FKUITS AND VEGETABLES

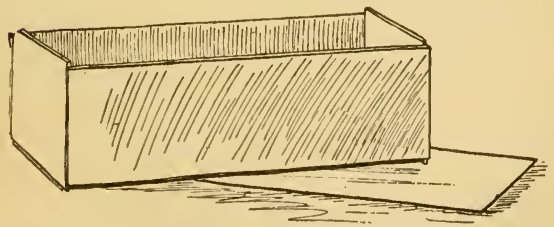

FIG. 32-SMALL BOX FOR FANCY FRUITS AND VEGETABLES

vegetables, such as beans, peas, tomatoes, cucumbers, onions, etc. Various sizes and modifications of the slat crate are extensively used by southern truckers. from Norfolk down the coast, for shipping cabbage, cauliflower, spinach, and all sorts of vegetables. 


\section{SUMMARY OF PACKAGES}

The various packages chiefly used in shipping fruits are arranged in the following tabulation, which also shows the approximate cost.

Fruit

$$
\text { Package }
$$

Cost

\begin{tabular}{|c|c|c|}
\hline pple & $\begin{array}{l}\text { Barrel, roo quarts, or } 3 \\
\text { bushels. } \\
\text { Box, various sizes. } \\
\text { Slat crate, mostly half } \\
\text { bushel } \\
\text { Basket, mostly bushel. }\end{array}$ & $\begin{array}{l}\$ 25 \text { the Ioo } \\
\text { Variable } \\
\$ 4.50 \text { the } 100 \\
\$ 1 \text { to } \$ 1.25 \text { a doz. }\end{array}$ \\
\hline each & $\begin{array}{l}\text { Delaware basket } \\
\text { Michigan basket, one-fifth } \\
\text { bushel } \\
\text { Six-basket carrier } \dot{*}^{-} \cdot{ }^{-}\end{array}$ & $\begin{array}{l}\$ 2 \text { to } \$ 3 \text { the Ioo } \\
\$ 3 \text { the Ioo } \\
\$ 7 \text { to } \$ \text { Io the roo. }\end{array}$ \\
\hline & $\begin{array}{l}\text { Barrel, } 3 \text { bushels } \\
\text { Half barrel, } 1 / \frac{1}{2} \text { bushels : } \\
\text { Boxes and baskets of va- } \\
\text { rious kinds. }\end{array}$ & $\begin{array}{l}\$ 25 \text { the } 100 \\
\$ 15 \text { to } \$ 20 \text { the } 100\end{array}$ \\
\hline
\end{tabular}

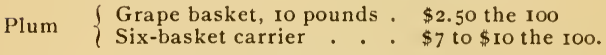

Cherry $\left\{\begin{aligned} & \text { Strawberry quart boxes } \\ & \text { and crates } .+. \quad \begin{array}{l}\text { Quart boxes, } \$ 2 \text { to } \$ 3 \\ \text { the } 1,000 ; \text { I6-quart } \\ \text { crates, } \$ 5 \text { to } \$ 6 \text { the } \\ \text { I00 }\end{array} \\ & \text { 5-pound grape basket. }\end{aligned}\right.$

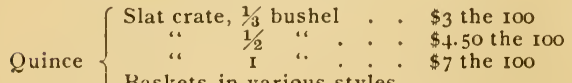

Baskets in various styles. Also barrels.

Berries \{ Quart boxes in crates.

$$
\left\{\begin{array}{l}
\text { Quart boxes, } \$ 2 \text { to } \$ 3 \\
\text { the } 1.000 \\
\text { I6-quart crates, } \$ 5 \text { to } \\
\$ 6 \text { the Ioo } \\
24 \text {-quart crates, } \$ 7 \text { to } \\
\$ 15 \text { the Ioo }
\end{array}\right.
$$


IX. WRAPPING FRUITS

California fruits, which are in many ways a model to every shipper, frequently come to eastern markets wrapped in tissue paper. Hustling eastern shippers have experimented somewhat extensively along this same line, but, apparently, without having arrived at any very definite conclusion. It may be safely said, however, that only the fanciest grades of fruit will pay for the expense of paper and wrapping. Canadian fruit growers, who send a greater proportion of their products to the European markets, have naturally done relatively more with this matter and have had more positive results. When our export fruit trade reaches greater proportions we shall doubtless do more wrapping in the states. There are already various brands of paper on the market in cut sizes suitable for fruit wrapping. Any grower who is producing a fancy grade of fruit for a fancy market is advised to try wrapping in an experimental way. Others had better let it alone.

\section{$X$. MARKS ON PACKAGES}

Very much of the grower's success depends on making a reputation for his fruit-much more than is commonly supposed. The man who ships to the city market frequently imagines that his identity is lost sight of and his responsibility swallowed up in the mixture of all men's products in the commmission house. This may be the case to some extent, but it need not be so at all. If a grower has any expectation of staying in the business and any ambition to make what money he call out of it, it will be much better for 
him to maintain lis own responsibility for his own fruit and get all the credit he call out of it.

A few commission nen, especially in European markets, object to having a grower's private mark on the package. In this country most dealers welcome such an advertisement from the grower The simplest

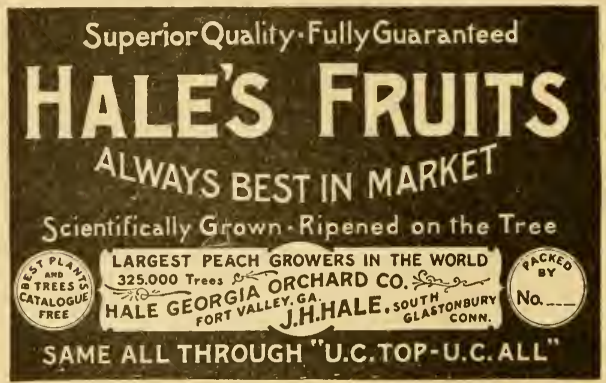

F1G. 33-THE FAMOLS HALF LABEL-ALWAYS PRINTED IN RED, AND PUT ON SELECT GRADES OF FRUIT ONLY

way is for the grower to stencil his name and address, or the name of his fruit farm, on each package. I have heard some wise horticulturists recommend the propriety of adopting an appropriate and attractive name for the fruit farm for the specific purpose of advertising in this way. Some growers use a sort of trade-mark. One apple grower of my acquaintance marks his fancy fruit with a crown on each barrel head. When his commission man, who has liandled this fruit for years, gets a barrel stenciled with a crown it goes 


\section{FANCY MELONS FROM THE SAME FELLOW WHO GROWS}

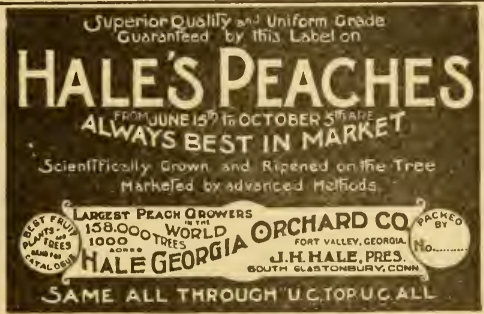

FIG. 34-HALE'S MELOV LABEL-A COMBINATICN OF A BLACK LABEL (ABOVE) WITH TIIE ISUAL RED LABEL

at the fanciest price of the day without further examination. The most noted private mark in this country is the famous red label of Mr. J. H. Hale, of Comnecticut and Georgia. His derice is reproduced (without the red color) in Figs. 33 and 34 . It has been worth thousands of dollars to him.

This matter of a suitable and effective private mark for the fruit package is one to be seriously considered by every grower. 

PART FIVE

Fruit Storage 



\section{FRUIT STORAGE}

Some sort of storage facilities are almost indispensable in the managenent of the fruit business for profit. They allow fruit to be carried over a season of glut, and so help the grower, even though the storage be owned by the speculator and operated in his interest. Fruit storage is most useful to the fruit grower, however, when it is kept in his own possession, or at least within his own management, for it makes him in a greater or less degree independent of the buyer and speculator-often remarkably so. It nuay be safely said that the fruit business can not be conducted on a large scale, except with a few of the more perishable fruits, without adequate provision for storage, either on the grower's own premises or in rented storage rooms.

\section{REQUIREMENTS}

The requirements for successful storage of fruits are three : (1) good fruit ; (2) proper handling ; (3) reasonable control of temperature in the storage room. We will consider these in order.

Quality of the fruit.-There are two reasons why poor fruit should never be put in storage. First, it does not keep. The shrinkage and loss are sure to be excessive. Second, the fruit is not worth it. Fruit storage is comparatively expensive business, and poor 
96 FRUIT HARVESTING, STORING, MARKETING

fruit will not pay for the extra trouble. The fine stables which the trotting-horse man has for his fivethousand-dollar racers would be wasted if used for the scrub ponies of the Texas ranges. Many men make the mistake of putting inferior fruit into storage; and when they fail, as they inevitably must, they condemn the whole storage business. I have heard some of those men speak in the horticultural societies.

Handling the fruit.-Two things are usually (though not always) necessary in handling the fruit if success is to be expected in storage. These are: (I) careful sorting and (2) subsequent rest.

A few men succeed fairly well in storing apples, grapes, and plums without sorting, or with only partial sorting. The only safe rule, however, is to sort all fruit carefully before sending it to the storage room." Wormy and diseased specimens must all be removed. A rotting plum or apple spreads the infection quickly to all the fruits which it touches. This fact is so well supported by wide experience that it need not be argued any further.

After the fruit has been picked, sorted, and put into storage, however, it should be left alone. Any further handling will do more damage than good. This rule is almost imperative. Many men think it necessary, or, at least, advisable, to go over fruit in the storage room from time to time and remove decaying specimens; but all experience goes to prove that this is bad practice.

Regarding the time when fruit should be picked to be put into storage there is the greatest diversity of 
opinion. It is evident that no general rule can be given. Spy apples should be left on the trees until colored if possible, even though that may keep them there a month after the first frost comes. Most pears, on the other hand, should be picked before fairly ripe, or even while yet green, and should be put into storage to ripen. Peaches and plums should be picked before quite mature. Varieties of apples which drop badly, like Wagener and St. Lawrence, must be picked early, while those which hold on well, like Tolman and Red Canada, are better left later. Practice will evidently vary with variety, locality, and special circumstances. Even with the same trees in the same orchard early picking may be advisable one year and late picking another. Weather conditions throughout the ripening season, and especially at picking time, exercise a very important influence. As nearly as one may make any generalization for apples, it would probably be nearest the truth to say that they should be left on the trees as long as circumstances make it safe for them to be there. For pears one might say that they should be picked and stored as soon as they have attained their full size and are partially colored. Plums, peaches, and similar fruits should be picked as soon as feasible. Grapes, like apples, should be left as late as they safely may be.

\section{SYSTEMS OF STORAGE}

There are practically three systems of storage for fruit, differing in the manner in which the temperature is reduced. These are: (1) mechanical refrigeration, (2) ice refrigeration, (3) cooling by rentilation. 
These are named in the reverse order of their importance, judged merely on the basis of their adaptability to the needs of the fruit grower.

I. Mechanical refrigeration.-There are various systems of mechanical refrigeration, but the plan of this book nuakes a consideration of them nnnecessary. Mechanical refrigeration undonbtelly furnishes the ideal cold storage, giving the most direct and easy control of temperature, usually at least expense when large quantities are landled, and generally with best results. The expense of installing and maintaining a plant, however, places mechanical refrigeration out of reach of the fruit grower, and makes it a business by itself. Even Judge Wellhouse, "the Apple King," with his hundreds of acres of bearing orchard, finds it better to rent cold storage room than to build a refrigerating plant of his own. I think I an literally correct in saying that there is not a single fruit grower, company, or association to-day in America maintaining a private storage plant cooled by machinery.

The fruit grower is interested in this system of storage, therefore, only indirectly. Space in cold storage compartments is frequently rented by fruit growers, this being nswally their sole connection with the business. The only practical questions under these circumistances are: (I) Is this method of storage successful? (2) What does it cost?

In theory mechanically cooled storage ought to be the most successful sort. Practically it does not seem to be conspicuously so. The drawbacks are: first, that refrigerating plants are not constructed primarily 
for the accommodation of fruit, but rather for meat, butter, eggs, and other merchandise; and, second, that proper adjustment of temperature and ventilation have seldom been secured. The latter difficulty is usually due either to ignorance or carelessness, and might be corrected; the former is harder to reach. In some cases, where storage rooms cooled by machinery have been properly managed, the results have been all that conld be desired.

As to cost, there is great variation in practice. The business of fruit storage in rented rooms is not yet common enough so that the owners of storage louses have been able to make a uniform rate. Moreover, circumstances differ greatly in different parts of the country. Ronghly, the expense ranges from ten to twenty-five cents a barrel a 111onth, or from twentyfive to fifty cents a barrel for the season of six months. Fifty cents a barrel for six months may be looked on as the standard rate, but a standard which is seldom maintained. Material reductions are made when quantities of fruit are stored, and the rate is reduced for various other considerations, so that thirty to thirtyfive cents a barrel for the season comes nearer being the rate usually paid.

These prices are reckoned for apples in barrels. Other fruit, as grapes, peaches, or strawberries, is sometimes stored for periods varying from a few days to several weeks. In such cases rates are fixed by agreenent. There is no accepted standard.

2. Ice refrigeration.-The use of ice for cooling fruit storage rooms is often practicable on farms, 
especially in the northern states and in Canada. The principal difficulty is that the ice is needed chiefly in the late fall, so that it has to be carried all summer, through the full season of greatest waste. Usually, however, a comparatively small quantity is required, merely enough to cool down the rooms and the fruit

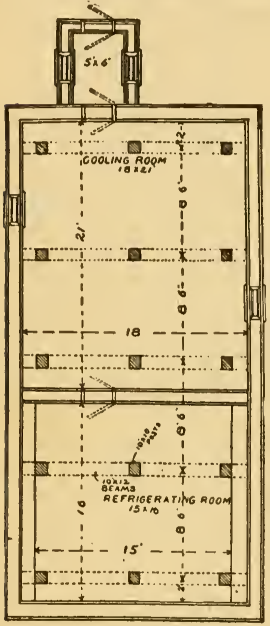

FIG. $35-S E C T I O N$ UF STORAGE HOUSE DESIGNEI BY FAVILLE AND IIALL. when the storage season commences.

It is practically necessary, to make use of ice for cooling a storage room, that the ice be placed in a room or chamber above the storage space, unless some special system is used such as is described hereafter. This necessity presents a serious inconvenience - namely, that the ice cannot usually be stored and kept where it is to be used. If the fruit storage room could be under the ice house the arrangement would be ideal and the whole thing could be planned with ease. But it is highly impracticable to make an ice house of the second story of a fruit house and to keep ice there through the entire summer. This means, practically, that under ordinary circumstances the fruit house and the ice house must be separate. They may be close to- 
gether, or even built one against the other; but when the fruit room is to be cooled the ice has to be handled out of its storage quarters and put where it is needed.

The usual method of using ice for cooling a fruit room is to place it in quantity in a room above, arranging the ventilation so as to let the cool air flow down from the ice room into the fruit room and the

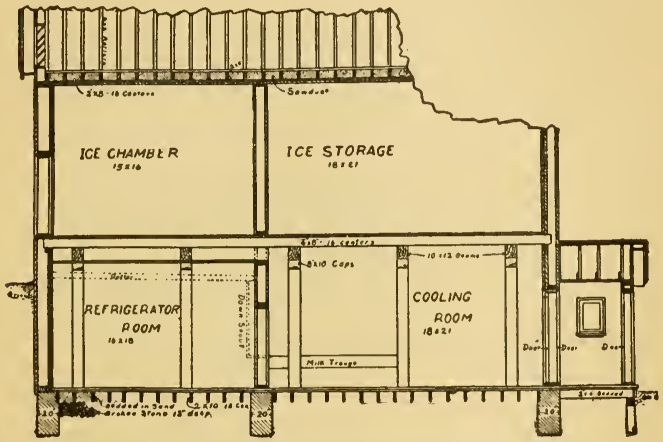

FIG. 36-CROSS SECTION OF FAVILLE-HALL STORAGE HOUSE

warm air to be carried off through flues or shafts. The cool air is best allowed to flow down at the sides of the building behind guides, which bring it nearly to the floor, in which case the warm air exit is placed in the center of the room and opens near the ceiling. The accompanying illustration of a storage house described by Faville and Hall (Kansas Experiment Station Bulletin 84, April, 1899) shows this arrangement reversed, the cool air coming in near the middle of the 
ceiling and the warm air going up at the sides. If the house were arranged exactly as shown in the diagram, however, the circulation would be mostly in the upper part of the room, the air below remaining comparatively stagnant.

W'ith regard to this particular building, Messrs. Faville and Hall say that it is designed to be located in a hillside of such a slope that the first floor will be on the level of the surface at one end and the second floor a few feet above the surface at the other. The building is $18 \times 38$ feet, interior measurement, two stories in hight, and divided into four rooms, two on each floor. On the second floor is the ice-storage room, $18 \times 2 \mathrm{I}$ feet, in which the future supply of ice is stored, and the ice chamber, $15 \times 16$ feet, in which is held the ice that cools the refrigerating room directly below. A door in the ice chamber communicates with the outside. This is for the unloading of ice and is the only ottside entrance into the second story. The refrigerating room is $16 \times 18$ feet, and is the compartment in which the temperature is to be reduced, and in which perishable products are to be stored. Leading into this room is the cooling room, $18 \times 21$, which is to be used as a general purpose storage cellar. A small entrance room protects the doorway into the cooling room. This is the only entrance to the ground floor. . . . The flooring is laid tight in the storage room and provided with a slope toward the center. A gutter catches the drainage and carries it into the gutter from the ice chamber. To prevent leakage the floor of the storage room must have a sheet-iron covering. The floor of the ice chamber is laid with $2 \times 4$-inch lumber 

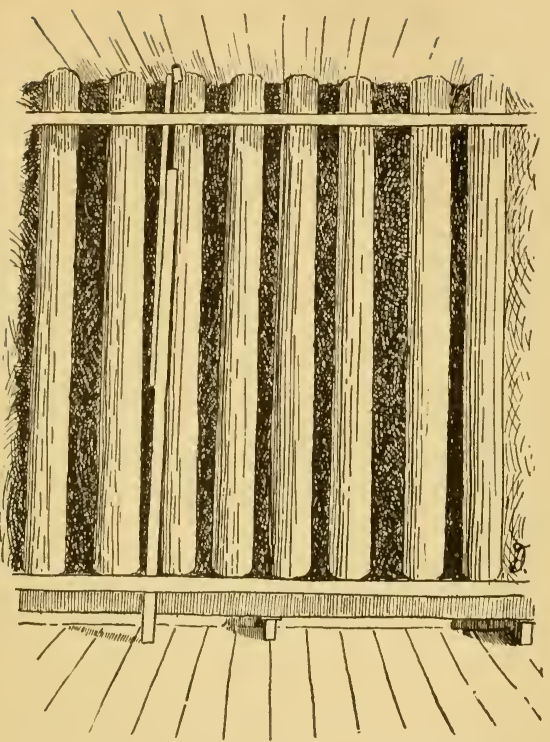

FIG. 37-ICE PIPES WITII WASTE TKOUGH BEL(W

with I-inch spaces between. This provides for air circulation and water drainage. A sloping catch floor leads the water into the gutter which carries it down and out through the cooling room.

Another method of cooling storage rooms with ice has come under the writer's observation in the cold storage houses of Sinith Wright \& Sons, Williston, $V t$. These storage warehouses have been in success- 
ful operation for many years, and are used chiefly for storing dressed poultry, butter, and eggs. Around the sides of each storage room are set a series of vertical pipes. These are made of galvanized iron or steel, and have a diameter of approximately 8 inches each. These pipes stand closely side by side in a single rank. The entire row sits in a wooden trough, which carries off the water as the ice melts. The pipes extend through the ceiling of the storage room and terminate in a broad trough in the room above. In this upper

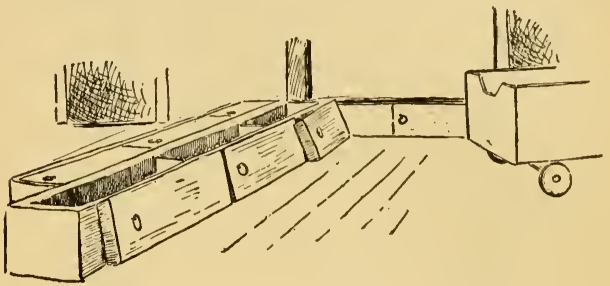

FIG. 38-TROUGHS FROM WHICH ICE TUBES ARE FED

room the work of icing the tubes is carried on. The ice is brought from the ice house on a suitable slide, and is crushed in a machine in the passage below. The crushed ice is swung up by a horse and tackle to the workroom above the storage room. Here the crushed ice is mixed with salt in definite proportions, and is fed into the cooling tubes by being shoveled into the trough already mentioned. The entire storage room is cooled in this way with the crushed ice and salt mixture, and operates, in fact, like a large ice-cream freezer. Any practicable temperature may be secured 
in this way and maintained without serious variation. For holding dressed poultry a temperature of 14 to 15 degrees is kept the year round. The temperature is controlled by regulating the proportion of salt mixed with the ice. From Io to 20 per cent of salt, by weight, is used for temperatures ranging from 45 to 12 degrees.

This construction has been found to be comparatively inexpensive in its first cost, to be fairly durable, economical, and efficient. The application of the same method to the cooling of fruit storage rooms seems to be entirely feasible. A room required for the storage of apples or grapes conld be cooled down at the time the crop was brought in, and the required low temperature could be secured at the critical season of the year-that is to say, in early fall. This is the time when the common storage room, cooled only by ventilation, presents its greatest shortcomings. If ice could be used for the first cooling of the newly picked fruit and to tide over warm spells in early fall, ventilation could be depended on with greater confidence for the remainder of the season.

The same principle has been used elsewhere-for instance, in Canada, in dairy refrigeration, and has proved entirely satisfactory. (See Canada Com. Ag. and Dairying Report, I897, p. 58.)

Mr. Arthur H. Hill, who has carefully examined this Williston storage plant, believes that the plan may be easily adapted to the needs of fruit storage. $\mathrm{He}$ plans to build an apple house employing this arrangement of pipes, and the construction which he has devised is shown further on in this chapter. 
IO6 FRUIT HARVESTING, STORING, MARKETING

3. Cooling by ventilation.-Probably the most practicable, and certainly the most economical, method of storage for farm use and for the ordinary fruit grower is that which depends solely on rentilation for regulation of the temperature. At first thought it seems that such means would prove inadequate, but wide experience has shown that, properly managed, a house cooled by ventilation is perfectly satisfactory for fruit storage in any of the northern states. This method grows less and less satisfactory, of course, as one moves southward, and I do not believe it is to be recommended for districts warmer than central New Jersey or central Missouri. It will succeed many times south of that latitude and will fail many times north of there. In the northern states and the provinces of Canada this system may be adopted with perfect confidence.

The requirements are about as follows: First, thorough insulation against outside changes of temperature ; second, adequate ventilation ; third, careful and constant attention, especially when the fruic is first put in, and before.

Walls are best made in two or three layers, with dead-air spaces between. The typical wall for a storage house of this sort is built upon $2 \mathrm{x}+$ studding. On the outside there is laid first a course of good incl boards ; over this is placed one or two layers of building paper, and the wall is finished with a course of tight, well-matched novelty siding. Inside the wall is built in much the same way. There is put on first a layer of inch boards, then one or two layers of paper, and finally the whole is ceiled and heavily painted. 
The painting is very important, as it preserves the ceiling from the disastrous swelling and shrinking which it would otherwise inevitably suffer through taking up the moisture giren off by the stored fruit.

If still greater pains are to be taken to make a wall impervious to heat two dead-air spaces are provided. These are secured by running furring strips along the sides of the studs between the outer and inner walls, and by lathing and plastering on these. When such a wall is built it is best to make the studs $2 \times 6$. Such a wall costs considerably more; but it is very much safer and well worth the extra expense.

Ventilation is secured only by means of windows in the houses commonly built. Even these are frequently placed with less regard to the currents of air which they will furnish than to the appearance which they will make on the outside of the building. Windows ought to be fewer and properly constructed rentilators more numerous-the fewer windows the better, in fact.

A ventilating system consists of an intake for cold air and an outlet for warm air, the two being properly disposed with reference to each other, and so arranged as to serve all parts of the room. The cold air should be admitted near the bottom of the room, or should be conducted there by suitable guides. Perhaps the ideal arrangement is to have the intake brought in beneath the floor, and to have the cold air brought up through registers at such points as may seem best. The warm-air exit must be placed in the upper part of the room. It acts much like a chimney, and the draft in it will be good or bad in accordance with the same 
IOS FRUIT HARVESTING, STORING, MARKE'TING

laws which govern the chinney draft. 'The length of the warni-air sliaft is therefore of some importance. If the room is nore than sixteen feet long there should be two ventilators; and, if very long, there should be one for every twelve to sixteen feet of rumning length. For a room $12 \times 12 \times 8$ feet the warm-air flue should be about 12 inches square, inside measure, with a length of 6 to 12 feet. It is a very good plan to have a light wire shelf placed inside the warm-air flue and somewhere near its middle hight. On this shelf a lighted lamp can be placed when a draft is required and when the difference of temperature outside and inside the house is not sufficient to start a circulation promptly.

Whatever the arrangement of ventilators, great care and constant attention are required to reduce the temperature by their assistance alone, particularly early in the fall while the days are still warm. The fruit house should be closed up tightly several days or even weeks before the fruit is to te put in. The windows should be closely blinded. Then whenever there comes a cool evening the cold air drafts should be opened. If the night promises to be decidedly coolcooler than the temperature already secured inside the house-the windows and doors may be thrown open. Then windows and doors must be closed early in the morning before the sun shines into the room and warms it all up again. As the temperature rises all the ventilators must be closed to prevent further circulation. Thus, by opening the ventilators nights and closing days, the temperature of the storage room is slowly reduced. When nights begin to be frosty the 
temperature can be reduced somewhat sharply, and if the house is well built there is very little loss during the day of the capital gained at night. An entirely satisfactory storage temperature of thirty-six to forty degrees may be secured in this way under favorable circumstances before the first of November, and a little later this can be reduced to thirty-two to thirtyfour degrees.

\section{HANDLING THE FRUIT}

The old-fashioned way of handling pears in storage is to place them on shelves. These shelves are uswally narrow and shallow. The plan of nsing shelving in the storage room has been applied to all sorts of fruit, and is still used to some extent, especially where only a small amount is to be handled. This is not practicable for large quantities of fruit, however, and probably its advantages under any conditions are largely imaginary.

A modification of the shelf arrangement is still nsed by the Colorado apple growers, and in a few other places where fruit is stored in shallow bins. This reduces the labor somewhat.

Vegetables are often, perhaps ustually, placed in bins in the storage room.

The method now most commonly applied to fruits, however, is to store them in the packages. Apples are nearly always stored in barrels, grapes in baskets, peaches in baskets, and so on. This is, all things considered, the best and most convenient way.

There is a difference of opinion among apple growers as to whether barrels ought or ought not to 
be headed up when put into storage. According to the writer's view it is largely a matter of convenience. If the barrels are to be emptied and the fruit resorted before being sent to market, it is better to leave the heads out. On the other hand, if the apples are to be shipped without further sorting they may as well be headed up at once, and the barrels will handle more easily.

There is also a difference of opinion as to whether apple barrels should stand on end or lie on the side in storage. It is hard to see how there could be any difference one way or the other.

The amount of fresh, warm fruit put into a storage room at one time should not be excessive. It is better to fill a room slowly, allowing time for each lot to cool. When a large quantity of fruit is placed in the storage room at one time it requires a considerable while for it to be cooled down.

\section{TEMPERATURES}

Fruit storage does not require a very low temperature. In fact, the temperature is necessarily much higher than that used for butter or meat storage. The freezing point may be looked on as the minimum for fruit, whereas it is the maximum for meat. This simplifies the problem and reduces the expense.

The best storage temperatures for all sorts of fruits and regetables have not been determined. Far from it. A fairly precise knowledge has been gained from experience with certain kinds more commonly stored; but while the following table presents the best data 
now available, it cannot be regarded as infallible, or as more than approximately correct.

APPROXIMATF, TEMPERATURES FOR STORING FRUITS AND VEGETABLES

\section{Degrees Degrees}

Apples, summer . $36-42$ - Strawberries . . 36-44

Apples, winter. . 32-35 Potatoes . . . 36-40

Pears, summer . 36-44 Onions . . . $34-38$

Pears, winter . 33-3s Cabbage . . 34-36

Peaches... . $36-36$ Beets . . . 36-40

Plums . . . 36-42 Turnips . . . 34-40

Cherries . . . 38-40 Celery. . . 34-38

Grapes . . . $32-36$

Different varieties, however, even of the same class of fruits, often require different temperatures for best results. Judge Wellhouse writes 11e, saying : "We have found that different varieties require a different temperature, but just what temperature is best for each variety we have yet to learn. Jonathan requires a much higher temperature than Ben Davis. From the experience we have had I should say that forty degrees would be near the mark for Jonathan, and thirty-two to thirty-three degrees for Ben Davis."

Some varieties are characterized by better keeping quality than others. This quality belongs to the variety, just as much as color, or form, or flavor. In an experiment made by the Canadian Experimental Farms, in which several varieties of apples were stored till May $28 \mathrm{th}$, the orcler of superiority in keeping quality was as shown below. The figures give percentages 
I 2 FRUIT HARVESTING, STORING, MARKETING

of apples remaining sound at the end of the experinent.

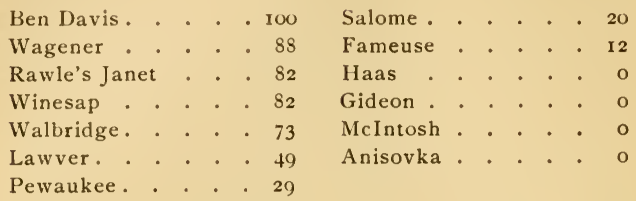

But fruits of the same variety differ greatly in keeping quality, and so in temperature requirements, when grown in different localities, or even from year to year when grown in the same orchard or vineyard. It is a common observation that the weather during the ripening period has a profound effect on the keeping quality of apples or grapes.

\section{GRAPE STORAGE}

Along with the recent remarkable development of the grape growing has come an extensive business in grape storage. An acquaintance of mine from the grape-growing district wrote me the other day (March I 2 th), "A neighbor of mine lias one hundred tons of Catawbas still in storage." 'The immense production of grapes, especially in certain neighborhoods in western New York state, and the uncomfortably low prices which often rule at picking time, have naturally forced growers to use every means of increasing the outlet and of extending the season. Storage is one of the readiest of these means.

At the beginning growers tried the cold storage companies, but the expense of rented storage was 
generally too great for the low price of grapes, and this practice never made much headway. The very low price of grapes, in fact, made it positively necessary that any storage must first of all be comparatively inexpensive; and as the cheapest possible system is that of home storage in ventilated houses, this method came into most common use.

The system of storage in houses cooled by ventilation has thus come to be the one generally practiced. It is successful beyond what might have been hoped in advance of experience. Indeed, the system seems to be as effective in keeping grapes as it is in keeping apples-that is to say, it is as satisfactory as any ordinary practical piece of hard work is ever likely to be.

The houses or storage rooms used for grapes are exactly like those used for apples. The houses described in subsequent pages of this chapter and the designs given are mostly for apple storage; but this is merely because this crop has come under my more immediate observation. I wished to write this account as far as possible from my actual personal knowledge, and I trust such a course will seem justified in the eyes of the reader. But any of the houses herein described could be adapted to grape storage, usually without material alteration.

Mr. Trevor Moore, of Hammondsport, N. Y., in the center of one of the largest grape producing districts in eastern North America, has been very successful in growing and storing grapes. I am indebted to him for much valuable information on this subject. He has also furnished me with the following descrip- 
tion of an unusually large and effective storage house owned by his neighbor, Mr. J. S. Smith.

The house is $60 \times 60$ feet on the floor, with studding 16 feet high. These are $2 \times 6$, and are papered and ceiled on each side and filled with sawdust between. The lower and upper floors are made double and filled between with sawdu:t the same as the walls. The entire building is placed above ground. There are several intakes for cold air on the east and west sides just above the floor. These are $3 \frac{1}{2} \times 2 \frac{1}{2}$ feet each, and are closed with tight doors like those used on refrigerator cars. There are two warm-air shafts from the upper floor through the roof and extending 8 feet above the comb. In each there is a shelf on which a lamp may be set to start the circulation of air when necessary.

This building, which differs in no essential respect from the apple storage houses more explicitly described in this chapter, and which is a type of the growers' storage houses in the grape districts of western New York state, has been entirely successful in its operations. Grapes, particularly Catawbas, are held here till April or May in perfect condition without the help of any artificial refrigeration whatever.

\section{STORING VEGETABLES}

Many sorts of vegetables are extensively stored each year. Thousands of bushels of potatoes are carried the year round by dealers, and growers often hold their stocks for many months. Cabbages, turnips, carrots, beets, salsify, parsnips, and all similar vege- 
tables are stored in great quantities and with general success.

Vegetables are usually stored in pits or in root cellars, such as will be described further on in this chapter. Mr. Dean Ferris, market gardener, of Peekskill, N. Y., who is very successful in keeping vegetables, has given me a description of his methods, which I reproduce entire. He says: "We dig carrots in October, put them in conical heaps on the surface, containing ten to fifteen barrels each, cover with the tops, and leave thus until approach of cold weather, when they are covered with soil at intervals as the weather gets more severe, until the covering is about one foot deep. Beets are also stored at the same time and in the same manner. Parsnips, salsify, turnips, rutabagas are not gathered until November, and are then treated the same as carrots. Horseradish is dug as late in November as it is safe to leave. It is put in heaps of not over seven barrels each, and with a liberal amount of soil mixed through it at the time each basketful is emptied. Horseradish sets require more care, and are put in heaps of two or three barrels, with as much soil mixed through them as possible. Onions are stored in a dry loft where it freezes, and those intended for spring market are allowed to freeze and are then covered with hay or straw to a deptli of nearly a foot, and this is not removed until the frost is entirely drawn out. Those for winter sales are not allowed to freeze nor to grow with too much heat. The best temperature, I think, is just above thirty-two degrees. Squashes and pumpkins are best kept in a dry place where the thermometer will indicate forty to 
fifty degrees. Cabbage we place on the surface in four rows, each block containing twenty-five to one hundred heads. They are pulled as late in November as possible, and must be bright and clean to keep well. They are covered as are the carrots, leaving only the roots exposed. For use until February, we cut the heads, put them in long piles, cover with boards like the roof of a house, and then cover with soil as often as necessary. Celery is stored in trenches in November, the trench being about the same depth as the celery. They are placed upright as they grow, about five heads being in each course, and the trench may be any length. Cover with boards, to be followed later with soil, like carrots, etc. Our cellar is small, and we keep only enough vegetables in it to supply our trade for about a month. Potatoes we store in barrels in the cellar, keeping them in the dark. The best temperature for storing most vegetables is about thirtyfive degrees, and for all roots the surrounding air should be quite damp. If I was sure that the snow would last all winter, I would place cabbage on sod ground, heads down, and cover with snow. When this can be done the cabbage comes out in spring as nice and green as when covered. We can not winter over spinach unless our fields are well covered with snow the entire winter. For late keeping we sometimes allow parsnips and turnips to freeze in the pits, and do not remove until the frost is all out, when they come out nearly as nice as when stored. I prefer our plan to cellars or root houses. I have tried a celery house and gave it up." 
VII. STORAGE IN PITS

This is undoubtedly the oldest form of storage for fruits and vegetables. It las been in use almost everywhere on this continent since the days of the first settlements. The Indians and the mound-builders nsed it, but that is really not to be considered a precedent. The method is better than it looks. At first sight it seems slovenly and makeshifty, but in reality it gives excellent results at small expense. Apples used frequently to be stored in pits, but the practice is waning as applied to fruits. Potatoes, sweet potatoes, turnips, and cabbages are the regetables most commonly stored in this way.

The usual procedure begins by making a shallow excavation, into which the regetables are put. In positions where perfect drainage can not be secured the excavation is omitted, and the vegetables or fruits are piled directly on the ground. In either case the vegetables or fruits are piled up into a high coneshaped figure. Sometimes they are put on carefully in concentric layers with rounds of straw, chaff, leaves, or sawdust between. This precaution is probably wortl while, as it secures some ventilation, facilitates drainage, and separates the fruits so that decay spreads less quickly from one to another. Sometimes a rentilator is placed in the middle of the heap. This may best be a simple box tube five to eight inches square, made of four boards nailed together. It should be liberally perforated with augur holes throughout its length. On top some sort of cover is placed to prevent rain or snow from falling in. 
Excessive quantities of fruit or vegetables should not be piled together. Fifty bushels or less may be considered best, though this linit is often greatly exceeded. Personal experience under definite conditions is the best test. Several sorts of vegetables, as onions and cabbages, should not be included in the same pit.

When the heap of fruits or vegetables is complete a covering of straw or leaves is put on. This covering may be held in place temporarily by loose boards laid o11. It is desirable to keep the pile for several days, or even for weeks, without additional cover. This allows the vegetables to cool down and to evaporate a certain amount of water. As the weather grows colder some soil is shoveled onto the straw covering. This earth cover is put on, a little at a time, from day to day, thickening as the cold increases, until, by the time the ground freezes for winter, the pit is adequately protected against the severest freezes which are to be expected.

The essentials of this method of pit storage are: (I) good fruit or vegetables, mature and free from decay; (2) careful handling; (3) perfect drainage; (4) proper ventilation; (5) progressively supplied and adequate protection from cold, but not such a covering as will prevent the proper cooling off of the contents of the pit. The advantages of the method are convenience and economy. In the opinion of the author the use of storage pits should be much more common than it is. There seems to be a notion that it belongs only with frontier conditions, and it has generally been practiced only in new countries.

My friend and former student, Mr. O. M. Morris, 
has recently made public his observations of this form of storage in the comparatively new country of Oklahoma.* His descriptions and notes are of so much general interest, that I will copy them here:

"Storing potatoes, sweet potatoes, turnips, and beets in pits over winter is practiced in Oklahoma and the surrounding states to a considerable extent and with widely varying degrees of success. Some men keep their root crops over winter in pits, with a loss of not more than one per cent, while others lose their entire crop. There are many conditions that will contribute to the loss, and sometimes it is quite difficult to meet all the conditions required for successful storage in pits.

"The condition of the crop to be stored is of prime importance. It should be matured, free from decay, cuts, bruises, sun-scald, and the effects of frost. Sweet potatoes are very susceptible to the effects of frost and other injuries. Potatoes should be carefully sorted before they are placed in the pits for winter. All tubers that are not in good condition should be thrown out. It is best to place the crop in storage as soon as dug. The best results are had when the potatoes are kept a little moist and not allowed to dry in the open air.

"The conditions for storage required by any crop are about the same, whether these conditions be furnished by cellars, storerooms, or pits. The material used in the construction of pits, however, is of a very different character from that used in other storerooms, and is more dependent on its character and surroundings for its utility. The pits should be so located that they will be partially or entirely shaded from the sun. This is almost necessary to maintain a low, even temperature. The best position is among trees or on the north side of a building. Excessive moisture can be avoided by giving good drainage. Sloping land with an open subsoil is the best, but any kind of soil is good if it is well drained so the water will not seep into the pit. If a desirable location

* Conntry Cicntlentan, $66: 276$. 1901. 
for a pit is not at hand, bad drainage may be overcome by simply piling the potatoes on the surface of the ground and covering. If this is done, the covering will need to be much thicker than for pits. It is best to have the potatoes on two or three inches of hay or straw, and covered with about the same thickness. The covering should protect from frost and turn water well.

"The pits should be round, or long and narrow, so that the pile may be in the form of a cone or rick. The potatoes should not stand more than three feet deep in the pile. Small piles containing from six to ten bushels have nearly always given the best results in this locality. The power of the soil to absorb noxious gases is depended on as the only source of ventilation, and can not act successfully in large piles. Sometimes large pits are ventilated to advantage by placing a trough or piece of drain tile in the south side of the pit near the top. The tile is placed in a horizontal position, with one end in the straw that covers the potatoes and the other just outside the covering of soil. Another ventilator of the same form may be placed just at the surface of the ground. The ventilators must be closed and covered during very cold weather.

"A large proportion of the loss of root crops in pits is due to the crops being unfit for storage when placed in pits. This point can not be too closely watched. If this loop-hole for decay is carefully guarded and good drainage secured, the remaining requirements can be provided at will. The protection from the sun and from frost required will depend largely on location."

It is better, when such a pit is opened, of course, to take the entire contents out at once. However, it is often feasible to make a small opening in one side, and to remove the potatoes or turnips a few at a time. I remember well how, when I was a boy, I used to be sent to the potato pit day after day to get enough for dinner; and no less an authority than Mr. John Bur- 
roughs tells his experience of going to the straw-covered pile of apples, thrusting his arm in full length, and feeling about for the variety of his choice. The continual removal of small parcels from day to day, however, is more apt to result in loss with apples than with potatoes or turnips.

Hardly any other fruit except the apple will submit to this method of storage, and the writer does not urge even this as a brilliant success. Among vegetables it finds a wider range of usefulness. Those which can be satisfactorily handled in this manner are potatoes, turnips, rutabagas, cabbages, sweet potatoes, beets, mangels, carrots, parsnips, salsify, and late squashes. The order in which these are named is approximately the order of their amenability to the treatment under discussion.

VIII. STORAGE IN "DUGOUTS" OR "CAVES "

The "clugout," or "cave," which is frequently found on western farms, is one step removed from the storage pit toward the real storage house. The dugout seems to be a western institution. In the winter it is used for storing fruit and vegetables, and in the summer it becomes a refuge from threatening cyclones. I have often been waked up in the night to run for one of them. I lived in Oklahoma then, and refuge from cyclones was much more important than storage for apples. S:ill, the "cave" was used for holding various perishable products even during the cyclone season; and the frightened denizen, precipitately arriving at one o'clock in the morning, night find himself buttoning his trousers and rubbing his eyes among pans 
of milk, dislies of butter, and remnants of yesterday's dinner. There may be "caves" and dugouts in the east, but I have never seen them. Even the word "cave" in this connection is, I think, of the west, western.

The dngont is made by digging into a hillside, if one is available, and making the walls of earth so far as possible. Sometimes the walls are lined with boards, and sometimes these ${ }^{1}$ ining-boards are rum round on studding set against the earth walls. Sonnetimes, however, and not seldon, the earth walls are unlined. Even the roof is commonly made of earth. Rough beams are laid for a ridge pole and rafters; these are covered with brush, and the earth is shoveled on. A well-built and properly managed "cave" of this sort will grow a crop of pigweeds on top. The last desideratum has been secured when a grass turf is settled over the roof, but good luck seldom goes so far as that in Oklahoma.

A ventilator is sometimes put into the conventional dugout; sometimes not. For purposes of storage a good rentilator is highly important (and I think it would be appreciated by the crowded occupants on cyclone nights). The dugout necessarily has a cloor also, but it seldom or never lias a window.

According to my rather extensive observation of these examples of farm buildings, they would be greatly improved for storage purposes by the adoption of some rational means of ventilation. This night be provided by making a good-sized flue on top at the end opposite the door, and ly making a cold-air inlet in the botton of the door. A sliding window two feet square in the 
lower part of the door would adnit cool air, which, as it becante warmer, would pass ont of the flue at the opposite end.

The usual dugout fails to be an efficient storage room for one other reason, and that is that too many kinds of things are put into it. I have not infrequently seen potatoes, sweet potatoes, cabbages, onions, apples, and butter in the same "cave," or some other equally unfriendly mixture.

The dugout seems to me to be worthy of more general adoption on farms where no sort of storage is now provided. It seens, further, to be worth taking more seriously on the farms where it already exists. I believe it has considerable posisibilities in the storage line if properly managed. In particular it ought to be tried on small farms in the eastern states. No further directions or specifications for construction need be given, for there is notling elaborate or difficult in the architecture, and each man will naturally make his own dugout to suit his particular circunstances.

\section{MR. T. L, KINNEY'S HOUSE;}

The apple storage house of Mr. T. L. Kinney, of South Hero, Vermont, is one of the best I have ever seen. It may be taken as a type of the private fruit storage house. It is well built, and has been entirely successful. Apples have been stored in it in considerable quantities every year since it was built, and have kept admirably without exception.

This house was built in I888. It is $30 \times 50$ feet. The main story is 8 feet 4 inches high in the clear; 
the basement is 7 feet 4 inches high, and the loft, or second story, is 7 feet high.

The framing construction is simple, and much like that commonly used in barn building.

The large room on the main floor is used primarily as a sorting and packing room, bitt can also be used

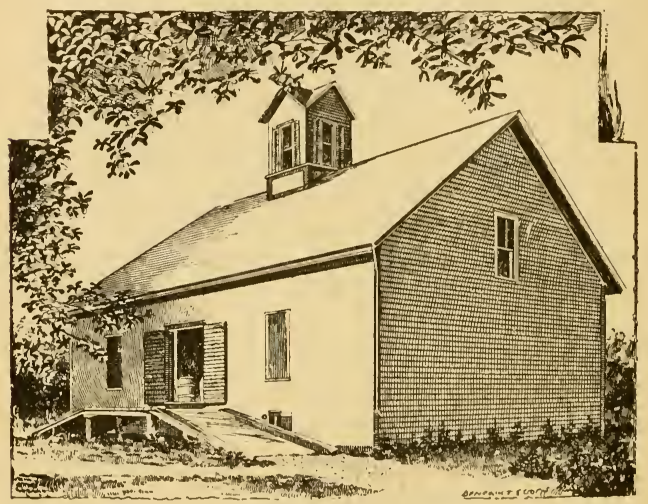

FIG. 39-MK. KINNEY'S APPLE STORAGE HOUSE.

for storage when the basement is filled. It will hold I, ooo barrels, piling the barrels three tiers high, which is as convenient as any way.

The basement is the main storage room. The apples are let down to this from the main floor by an elevator. This basement also has an outside door at the end opposite the one shown in the perspective (Fig. 39). Barrels may thus be nuloaded or loaded 
without being carried through the main floor. This basement room has no floor except for some loose boards laid down to keep the barrels off the earth. It has several small ventilating windows near the top, and the door is closed with a heavy double-planked door, which is kept shut after cold weather sets in. This room also has a capacity of $\mathrm{I}, 000$ barrels.

The upper story is used as a storage for empty barrels, coopers' stock, etc.

The main door opens upon the first floor. The sill is about 3 feet 6 inches from the ground; but the door

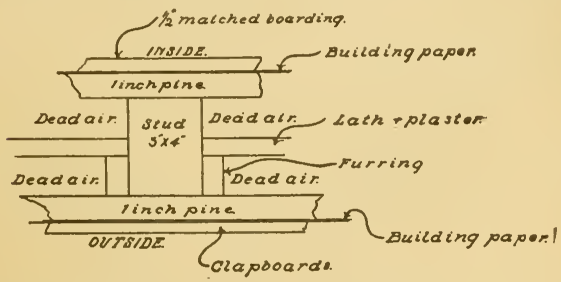

FIG. to SECTIUN OF WALI.

is approached by a driveway, shown in the illustration (Fig. 39). The windows are of glass and covered outside with heavy board shutters.

The roof is of slate.

The outside finish consists of three layers, as follows: (I) a layer of I-inch matched pine, (2) a layer of building paper, (3) a layer of clapboards, well painted.

The inside finish is also of three layers: (I) a layer of I-inch matched pine, (2) a layer of building paper, 
(3) a layer of lalf-inch matched boarding, heavily painted. The painting is important.

Between the outside cover and the inside finish, and between the studding, there is another layer consisting of lath and plaster. The position of these various parts will be better understood by reference to Fig. 40.

This leaves two dead-air spaces in the walls, one on each side of the layer of lath and plaster. Mr. Kinney says that if he were building again he would have the studding wider-say, $2 \times 6$-in order to make the walls thicker and the dead-air spaces larger.

In the construction of this house the following bill of lumber was used:

BILL OF LUMBER FOR APPLE HOUSE

3,500 feet wall boarding

3,000 " roof boarding

3,500 " ceiling (inside)
4,000 feet clapboards

25 bundles lath

$22 \frac{1}{2}$ squares slate

7,200 feet floor boards (double floors)

OUTSIDE, FINISH

200 feet 5 in. crown mould

I90 " 2 in. bed mould

300 “ "7 8 io mould for frieze and facia

200 “ $78 \times 7$ base and water tables

200 " 8 X 12 planers

\begin{tabular}{|c|c|c|c|c|c|}
\hline \multicolumn{2}{|c|}{4 piece } & $5: 8 \times 5$ & $15 \mathrm{f}$ & eet & \multirow{2}{*}{ f Corner boards } \\
\hline 4 & “ & $78 \times 6$ & I 5 & “ & \\
\hline 8 & “" & $2 \times 8$ & 15 & "“ & S sills \\
\hline I6 & “ & $2 \times 8$ & & $“$ & \\
\hline 56 & “ & $2 \times 9$ & $15 \frac{1}{2}$ & 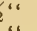 & Floor joists \\
\hline 26 & $" “$ & $2 \times 9$ & 30 & $"$ & \\
\hline 26 & “ & $11 / 2 \times 9$ & I9 & “" & Collar ties to rafters \\
\hline $\begin{array}{r}100 \\
20\end{array}$ & “" & $\begin{array}{l}3 x+ \\
3 x+\end{array}$ & $\begin{array}{l}\text { It } \\
12\end{array}$ & “ & Wall studs \\
\hline 56 & $\because$ & $2 \times 8$ & $2 \mathrm{I}$ & “. & Rafters \\
\hline 26 & “ & $2 \times 6$ & Io & “. & I Braces \\
\hline 26 & " & $1 \times 6$ & 8 & “. & s Braces \\
\hline 16 & “" & I $\times 4$ & I 3 & “ & Ribbons \\
\hline+ & "“ & & I3 & “ & Ridge poles \\
\hline
\end{tabular}

Lineal measure 
Responsible lumber dealers in Burlington estinate this bill at $\$ 443.69$. This house actually cost $\$ I, 500$, finished.

Mr. Kinney has furnished me with the following records of temperature observations, made during the winter of $1896-7$, and showing how well he is able to keep the rooms under control :

\begin{tabular}{|c|c|c|c|c|c|c|}
\hline Dute & & & & & $\begin{array}{l}\text { Cellar } \\
\text { Temperature } \\
\text { Degrees }\end{array}$ & $\begin{array}{l}\text { Main Room } \\
\text { Temperature } \\
\text { Degrees }\end{array}$ \\
\hline December & 25. & . & . & • & 35 & 32 \\
\hline ." & 29 . & . & . & . & 35 & 33 \\
\hline January & I. & . & . & . & $3^{6}$ & 33 \\
\hline ". & 2 . & . & . & . & 36 & 35 \\
\hline ". & 3 . & . & . & . & 36 & 37 \\
\hline “ & 4. & . & . & . & 37 & 38 \\
\hline “" & 7. & . & . & . & 37 & 36 \\
\hline “" & II. & . & . & . & 37 & 35 \\
\hline " & I4. & . & . & - & 36 & 32 \\
\hline “" & 17. & . & . & . & 36 & 34 \\
\hline “" & 19 . & . & . & . & 36 & 32 \\
\hline “" & 23 . & . & . & & 36 & 33 \\
\hline
\end{tabular}

It will be noticed that the temperature fluctuated more in the room on the first floor than in the cellar. This is due to two causes; - (1) there were more apples in the cellar than in the room above, and (2) work was going on in the upper roon, men were passing in and out, and the doors were frequently opened.

The practice is to cool the house as much as possible as picking time approaches. This is clone merely by attention to ventilation. The windows are kept open during the prevalence of cool westerly winds or during cold nights, and the house is kept tightly closed during hot weather and when the sun shines. 
The fruit is picked and sorted into barrels if there is sufficient help at picking time. The sorting is done on a sorting table kept out in the orchard. When, as sometimes happens, enough help can not be secured, the apples are only partially sorted or not sorted at all. They are put into the barrels and are taken to the storage house, where sorting follows during rainy weather. When the apples are finally carefully sorted they are put into barrels without heads, and are set away in the storage rooms, where they are left undisturbed till shipping time. In case of unusual developments of scab or other troubles, especially if rotting occurs, the fruit may be resorted during the period of storage. At any rate, the final sorting and grading is done at the time of shipment.

\section{A CANADIAN FRUIT HOUSE}

One of the most satisfactory storage houses of medium size which has yet come under my observation is the one owned by Mr. J. M. Fisk, of Abbotsford, Quebec. This is a frame building, $30 \mathrm{x} 20$ feet outside. It is built with 8 -foot posts, and double boarded with I-inch hemlock. This hemlock siding is laid in two thicknesses with the tar paper between. The whole is roofed with cedar shingles.

There is a cellar or basement under the whole house, which doubles its capacity. The cellar wall is of stone and mortar, 6 feet high and 2 feet thick. At the lower end it rises 3 feet above the surface of the ground; at the upper end, about i foot. The cellar is effectively tile drained, is furnished with a good cemented bottom, is lighted by three windows, with 
double sash for winter, and is rentilated by two 4 -inch tiles, which are closed in rery cold weather. The floor over the cellar is $2 \frac{1}{2}$ inches thick, 1 -inch lining with tar paper and $1 / 2$-inch plank. The floor above the packing room is 2 inches thick, of two layers of I-inch boards with tar paper between.

The packing and sorting room above the cellar is lighted by forr windows, 4 feet by 2 feet ro inches.

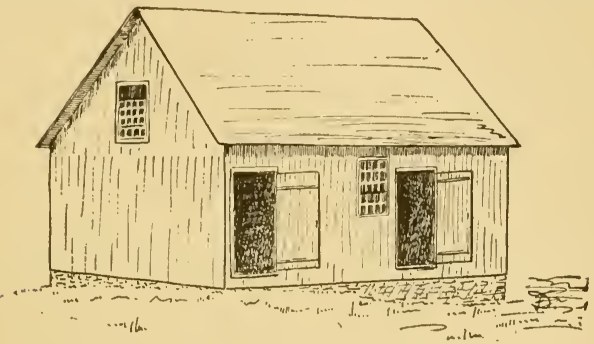

FIG. 4I-MR. FISK'S FRUIT HOUSE

The upper sash drops 6 inches for ventilation. There are two doors-one to load or unload from wagon without lifting barrels, the other for general use and to unload from dray.

The loft or upper story is approached by stairway at end of packing room. The only approach to cellar is near the center of building, by a lift which consists of a section of the floor, cut 4 feet by 4 feet 2 inches, and supported by four $5 / 8$-inch rods, one at each corner of the platform. These pass through and up to the ends of two stout cross-arms, made of white ash, 6 
feet 6 inches above platform; and on top and center of cross-arms is attached a 9 -inch pulley. This platform or open cage runs in groores of frame of chute, which consists of four upright scantlings, $5 \times 2$ inches, one at each corner, firmly secured to both upper and lower floors and botton of frame in cellar. The platform being a section of the floor, for loading and unloading, is held in position by a brake and lever attachment on top of the drum in the loft, and is operated from floor of packing room by a $1 \frac{1}{4}$-inch endless rope, which pasises twice around the drum in the loft, and down through either side of the platform to the bottom of the chute, over two small pulleys to keep it taut. The drum is 5 feet $1 / 2$ inches in diameter, with a $2 \mathrm{I}$-inch rim, and is built on the shaft. In operating, it winds and unwinds the rope over the shaft, the rope passing through the pulley on top of cage as it is lowered or raised from the cellar. The lowering and raising are facilitated by a 200-pound counterweight attached to shaft by a rope and pulley. Mr. Fisk says he finds the elevator a great convenience in handling the fruit, as it enables him to take advantage, without 111uch labor, of a good cellar to store apples and other fruits and vegetables during both hot and cold weather.

The cellar will store 260 barrels of apples, and the room above, which is designed for a sorting and packing room, may be converted into a storage room at a pinch, and will accommodate at least another 260 barrels. The loft or attic is useful for general storage. The cellar is the room in which apples have been kept hitherto. Last winter apples in barrels in the cellar 
suffered no damage, though the thermometer outside went down to 27 degrees below zero for a short time. No lieat was given, and no artificial refrigeration was required. The capacity of the house has not been severely taxed thus far, for, though Mr. Fisk had a market crop of oier 1,300 barrels this year, the exceptionally good local market which he enjoys absorbed the greater part of it almost direct from the orchard.

The foregoing notes are taken largely from an account published by the anthor in Country Gentlemanl, 66: 128, February I 4, I90r. Mr. Fisk says that he can not give an exact statement of the cost of the house, because a good part of the lumber was from his own wood lot, and was prepared at odd times. The labor of construction was not let out to a carpenter or contractor either. The house was essentially "home-nade." Perhaps this is a chief reason why it is remarkably well made. Mr. Fisk thinks, however, that $\$ 400$ would be a fair estimate of the cost of such a building in his neighborhood. He regards it as a good investment, and says his only regret is that he did not build sooner and on a larger scale.

\section{PROFESSOR ALWOOD'S STORAGE HOUSE}

Professor William B. Alwood, horticulturist of the Virginia Experiment Station, lias described in his Bulletin $5^{8}$ a storage house whicl lie built at Blacksburg, Va., and which involves a principle somewhat different from anything met in other fruit storage louses. The general construction of the house is also interesting. The following account of the house is adapted from 
Professor Alwood's bulletin, from which also the illustrations are drawn.

The essential features involved are: (I) a cellar excavated into a gently sloping hillside, and carried into the bank far enough to place the cellar room entirely below the surface of the earth, and yet gire an opportunity to enter the cellar easily by an inclined

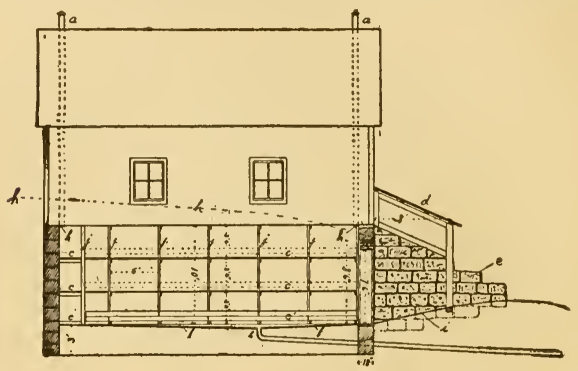

FIG. 42-PROFESSOR ALWOON'S STURAGE HOUSE

way from the lower side of the slope; (2) a flue leading out from near the center of the floor of the cellar room along the bank of the hillside for a considerable distance, with sufficient fall to make it act both as a drain pipe and a fresh-air flue; (3) ventilators placed at each end of the cellar room, and rising to a sufficient hight so as to give draft enough to carry off rapidly the air from the cellar room.

The cellar room will better serve the purpose of cold storage if the excavation is carried back into the bank so as to make the floor 12 or I5 feet below the lowest point of the adjacent hillside. In 
the case of the cellar built by Professor Alwood, the excavation is only ro feet deep at the deepest point, but he now feels satisfied that a greater depth would give better results. The principle of a subterranean air flue is the unique feature of this cellar. Its use is intended to secure a dry, even temperature in the cellar by admitting air as desired through this flue. It should be at least 6 inches in diameter, and should be laid at a depth of 8 or 9 feet for a distance of about 500 feet.

It is not necessary that this flue should lie in a straight line, but any departure from a straight line should be a gradual curve, so as to permit an unobstructed flow of air into the cellar. Situated at this depth and having a length approximately as stated above, the air flowing into the cellar through this flue will be in summer reduced, and in winter raised, to the temperature of the soil at the depth stated, which will approximate somewhere between $50^{\circ}$ and $55^{\circ}$ Fahrenheit during the entire year. The above statement is based on the observed temperature of perennial springs in the vicinity of Blacksburg, Va.

From the foregoing it follows that if the air in the cellar becomes warmer than the air in the underground flue, it will rise through the ventilating flues, and the colder air will flow in from the supply flue as desired. The temperature of the cellar room can thus be approximately controlled down to at least the neighborhood of $55^{\circ}$ to $60^{\circ}$ Fahrenheit.

The construction of the cellar is shown somewhat in detail in the drawings. These figures serve to bring out the essential ideas and plan of the structure 
sufficiently to enable any mechanic to carry them out on a larger or smaller scale to suit the needs of the builder.

Fig. 42 is a longitudinal section through the cellar room, and shows also a side elevation of the storeroom above. The two rentilators, $a \quad a$, rise through the. storeroom and are 6 inches in diameter by 15 feet long, thus insuring good draft. The air flue, $b$, enters under the foundation and discharges fresh air into the cellar room near the center. This flue is 6 inches in diameter, and, theoretically, should be extended far enough along the hillside to admit of tempering the air to the temperature of the surrounding earth while passing through it. The cellar under consideration has an air flue only i 50 feet long, and it has proved impossible to cool the air in the cellar room below $60^{\circ}$ with an outside temperature of $70^{\circ}$.

The dotted line, $h$, shows the surface of the ground on the hillside, and the line $i$ shows the level of the entry-way into the cellar. The entry-way should preferably be on the north side, and should be closed in by a vestibule, so as to protect the cellar-way from storm, and to prevent influence of outside temperature on the atmosphere in the cellar.

The roof of the vestibule is shown at $d$, and one side of the entry walls at $e$. The floor of the cellar, $f f$, pitches slightiy to the mouth of the air flue, $b$. The cellar floor is made of broken stone and cennent, and successfully checks the rise of ground water. The bins, or storage shelves, $c c$, etc., are of $2 \times 4$ scantling and $\mathrm{I}$-inch oak boards. The letters $k k$, at lower ends of ventilating flues, indicate the position of sliding 
dampers, by means of which the flow of air from the cellar is controlled. With the 150 -foot flue used in this cellar it has been found that when the mercury remains below $20^{\circ}$ for any length of time, the cellar will take a temperature below freezing unless the ventilators are closed.

Fig. 43 shows the ground plan of the cellar. The letters so far as used always indicate the same part of the structure in the section. The walls are constructed of stone, which is unquestionably the proper material.

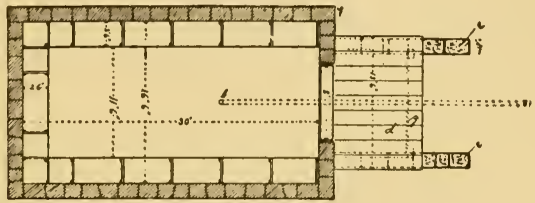

FIG. 43-CELlar PLAN OF HOUSE SHOWN IN FIG. 42

In the Virginia building, which was constructed to test the practicability of an idea new to this class of structures, expense was avoided so far as possible, and the walls were built of wood. The framing of the walls is constructed of $2 \times 4$ scantling, framed into sills laid in broken stone and cement. The corner posts are $+x+$ scantling. This frane is covered outside by a double sheathing of inch oak plank. The first course was put on diagonally and covered with strong builder's paper, and over this a perpendicular course of sheathing was put on. The whole structure was then literally soaked with crude petroleum, and the earth rammed in tight around the cellar story and 
I36 FRUIT HARVESTING, STORING, MARKETING

banked up so as to carry surface water away from the walls. Inside the walls were covered with inch oak boards, and the bins constructed as indicated in the drawings.

The entry-way to the cellar is wide enough to admit of backing a horse-cart or wagon down into the cellar so as to unload directly from it. This is a matter of much convenience to the workmen. The width of the cellar floor will allow of a row of barrels being placed in front of the bins and yet admit the vehicle.

With stone or brick walls the bins would need to be separated from the outer wall by putting up an inner wall of boards nailed to studding, thus giving an air space between the bins and the outer wall.

A series of observations on the range of temperature in the cellar was made during November, December, January, and part of February, I894, and the results are summarized below. The ventilator and the air flue were all left open from November ist to December Ioth. The outside air temperature was $28^{\circ}$ on the morning of November ist, and the cellar showed a temperature of $46^{\circ}$. As the month progressed a period of warm weather set in, without a drop to freezing, from the $7^{\text {th }}$ until the $24^{\text {th }}$ of the month. During this time the temperature often registered above $60^{\circ}$ in the shade, with maximum readings considerably higher. The cellar temperature varied just $12^{\circ}$ for the entire month, reaching $5^{\circ}$ on two occasions, but closing the month at $46^{\circ}$, with outside temperature at $34^{\circ}$.

During December the cellar temperature was reduced quite steadily from $45^{\circ}$ to $38^{\circ}$, the daily varia- 
tions being at most $2^{\circ}$. Outside temperature varied considerably, but the range was between $15^{\circ}$ and $46^{\circ}$. A number of observations were made on the working of the supply flue and the rentilators. The tests made showed that air passed through the 150 -foot supply flue in thirty to forty seconds, and the ventilators could be depended upon at all times to keep up a movement of air in the cellar so as to draw in a fresh supply. In fact, during the coldest weather the ventilators were frequently closed to prevent the too rapid lowering of the temperature in the cellar. The tests showed that this flue could not be depended on to raise the air to a proper temperature when the mercury outside was at $15^{\circ}$ or lower. The air was raised about $20^{\circ}$, the amount varying with conditions.

During January further experiments showed that the temperature of the cellar could be easily reduced to $35^{\circ}$ when the outside air was at $15^{\circ}$ to $20^{\circ}$. However, the building proved to be lacking in two essentials: (I) it was not deep enough in the earth, and (2) the floor between it and the tool room above was not properly laid. This floor is double, of half-inch stuff. It is now thought that the cellar room should also be heavily ceiled.

The total range of temperature in the cellar during January was $35^{\circ}$ to $42^{\circ}$. This result, howerer, was secured by carefully watching the conditions. An equally good result can not be secured, when outside temperatures are fluctuating, without constant attention.

Professor Alwood thinks that, with the improvements which have been suggested by experience, the 
I 39 FRUIT HARVESTING, STORING, MARKETING

building would become very satisfactory. In the opinon of the present writer the interesting and unique principle of an underground flue for tempering the air would be applicable to the storage of certain vegetables, such as sweet potatoes, and others requiring a comparatively high temperature. The plan seems to be practicable for securing even temperatures, but hardly adapted to give the low temperatures required in apple storage. If the temperature of the soil at considerable depths is about $50^{\circ}$, as observed from living springs by Professor Alwood, the buried flue ought to give, theoretically, an even temperature approximately the same. This is much too warm for apples and many other fruits. Of course such an underground flue may be used or kept closed, according as the temperature of the storage room is higher or lower than the observed subterranean temperature. It might, therefore, prove a convenience with any house, and would in no way interfere with the more drastic methods of lowering the temperature of the storage room, which the manager might find it desirable to adopt at certain times.

\section{A NOVA SCOTIA HOUSE}

The following description of a Nova Scotia apple storage house is furnished me by my friend, Professor F. C. Sears, director of the horticultural school at Wolfville. He says that apple warehouses are eacli year becoming more common in the great apple district of Nova Scotia, the Annapolis valley. They are built either by large speculators who deal extensively in apples, by English commission firms for the accommo- 
dation of their patrons, or by cooperative associations of the growers themselves, and are used either for the permanent storage of fruit or for temporary storing of apples as they are brouglit from the farm, and until they can be forwarded by rail to Halifax, and there loaded on steamers for England.

The illustration shows one of several which were built in 1899 wnder the direction of Mr. C. R. H. Starr, agent of Northard \& Lowe, of London. It is

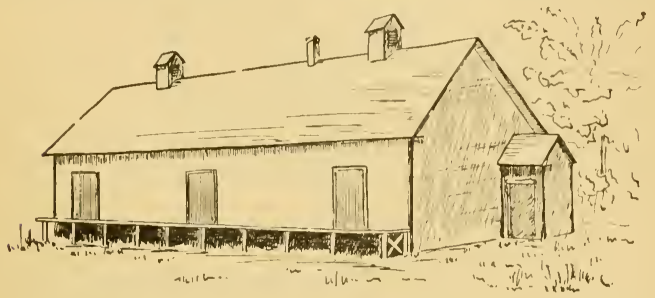

FIG. +H-A NOVA SCOTIA HOUSE

85 feet long by 20 feet wide, and has a capacity of about 4,00o barrels, with loading accommodations for three cars at one time along the side.

The building rests on a stone and brick cellar wall $\&$ feet deep, and the superstructure has walls ro feet high. The walls are covered, on the outside of the studding, with two courses of inch boards, with building paper between, and this again is covered with paper, with shingles on the outside. Inside the walls are first lathed and plastered with selenite and lime mortar. Then inch strapping is nailed 
against the studding, and the whole is covered with I-inch tongued and grooved spruce sheathing. The ceiling is covered with the same kind of sheathing, with building paper laid lengthwise of the joists between them and the sheathing. The upper floor is also laid double, with paper between, thus protecting the body of the building from frost from above.

The windows and door frames are made with double casings buried in the covering in such a man-

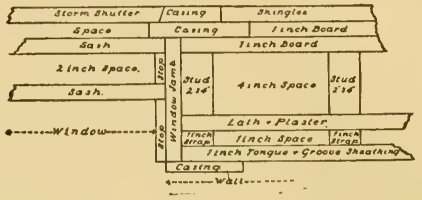

FIG. 45-SECTION THROUGH WALL ANI) WINDOW

ner as to preclude the possibility of draft or frost (see Fig. 45). The windows have double sashes, and are provided with storm shutters for protection against heat as well as cold. The doors are also double, one swinging outward and the other inward, and fitting closely into beveled jambs. These doors are built on 2-inch pine frames, with $\mathrm{I}$-inch tongue and grooved sheathing on each side of frame, and paper between.

There are three hatchways in the lower floor, provided with gratings, or tight hatches, if required. The ventilators extend from the ceiling to the roof, and are provided with slides to close when necessary. The cellar has also double windows and 4 -inch rentilator tubes in the sides. Both the cellar and the main 
floor of the building are proof against frost in the coldest weather, and altogether this warehouse is admirably adapted to the purpose for which it was built, and has proved invaluable to shippers.

\section{MR. T. B. WILSON'S HOUSE}

The house herewith illustrated and described is the property of Mr. T. B. Wilson, of Hall's Corners, Ontario County, N. Y. The following details regard-

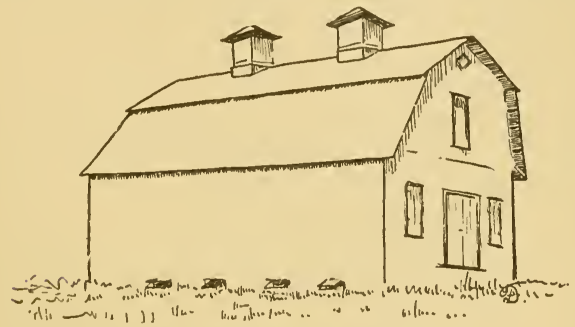

FIG. 46-MR. T. B. WILSON'S HOUSE

ing the construction and operation of the house are taken from an account published by Mr. S. A. Beach (Rural New Yorker, September I, I897).

The fruit is received by the door which opens on the first floor at the front of the building at a convenient hight for unloading apples from wagons. The rear door of the same floor opens above the railroad siding at a light of about 13 feet. From this door the barrels are run over a slide directly into the car. When barrels that are in the cellar are to be shipped 
they are lioisted to the first floor by horse power, and then loaded into the car from the rear door.

The dimensions of the building are $40 \times 60$ feet, outside measurement. The building consists of a cellar I I feet high in the clear-the first story of the same hight-and the attic, which is used for storing empty barrels, wool, etc. The combined capacity of the cellar and first floor is 7,000 pony barrels or 6,500 standard barrels. The cellar walls are two feet thick, made of small stones imbedded in grout. Five ventilators open into the cellar floor-one in the center and one in each quarter of the floor. From these one-foot pipes lead outside. The illustration (Fig. 46) shows four ventilators, which open outside the building near the ground, with doors by which the outside opening may be closed at will. The cellar has an earth floor and a ceiling of inch hemlock stuff.

The walls of the first story are 20 inches thick, made of small stones imbedded in grout. The inside of the wall is formed by a $2 \times 4$ studding set against the outer wall and covered with matched hemlock. The air space opens into the cellar below and into the attic above, and may be closed by a shutter in the attic, so that a current of cold air from the cellar may be sent through the air spaces wlienever it is desirable to do so. Over the hemlock ceiling of the cellar is laid about three-fourtlis of an inch of mortar between the sleepers. The floor of the first story laid on these sleepers is of two-inch matched pine. The ceiling is rough hemlock. Above this the space between the joists is filled solid with sawdust, over which are laid the inch hemlock boards which form the attic floor. 
The cellar has but one outsicle cloor, which is in the middle of the rear side. On either side of this door are two windows, the only ones which open into the cellar. In addition to the front and rear windows already mentioned, the first floor has three windows opening to the rear-one over the door and two in front, one on each side of the door.

The double doors are ceiled outside and inside, leaving a 2 -inch air space in the middle. Between the outer and inner doors is a 12 -inch air space. The windows are of single sash, protected by simple board shutters outside. The inside shutters are about 6 inches thick, with 3 -inch air space in the middle. The sloping jambs narrow outward. The first story is ventilated by $10 \mathrm{x}$ I 2 inch openings. These open into box flues which pass through the attic to the cupolas on the roof. These tubes are opened or closed by slides. Air is admitted through the windows and doors. The floor of the first story slopes gradually to the rear, so that barrels of fruit may be readily moved to the rear door, where they are easily loaded into the car.

Concerning the use of the building, Mr. Beach says further: "Shipments are made from here at any time during the winter by using refrigerator cars. It has never been necessary to build a fire in the building to keep the fruit from freezing. The temperature has been controlled by strict attention to the ventilation. Russets have been held here in good condition till May before being shipped.'

Mr. Wilson has frequently shipped apples to Europe from this building by the carload. He has 
144 FRUIT HARVESTING, STORING, MARKETING

also rented storage to others at a fixed rate by the barrel.

XIV. MRS. L. E. ALLEN'S STORAGE HOUSE

The storage house of Mrs. L. E. Allen, at South Hero, Vt., is interesting not only as being an entirely successful building of its kind, but also as exemplifying in its construction certain practical conditions which have frequently to be met. It often occurs that the fruit farmer does not care to build a fruit storage house out and out, bran new, from the ground up. He has some other building on hand which he can more conveniently make over, or some beginning from which he can enlarge to suit his needs. These were the circumstances which governed the planning of the house under consideration.

This house was built on a foundation already made, where another structure had stood, and the fruit room above the foundation was also built against another building already standing on one side. These conditions, of course, lowered the cost of construction considerably, and this must be remembered in examining the figures given below. Nevertheless, these conditions of construction occur so often that the case is fairly typical, and may be properly given at its face value.

The house consists of two rooms, the lower one being a basement with stone sides. This basement opens out on the level of the ground at one end, and is covered with earth to the top of the wall at the other end. The basement story is 7 feet 2 inches high inside, and the room above is 7 feet $71 / 2$ inches 
high. Each room is 43 feet 9 inches long by 17 feet 2 inches wide.

The outside of the upper story was first boarded on the studding, then covered with tar paper, and clapboarded on top of this. Between the studding it was lathed and plastered. Inside it was ceiled up with matched spruce, and a wainscoating of hard pine

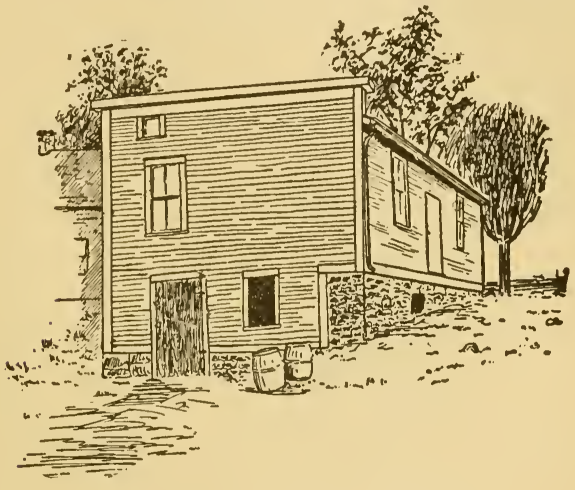

FIG. 47-MRS. ALLEN'S APPLE HOUSE

was run round. The main floor is double thick, with tar paper between the layers. The basement has 110 floor, but loose boards are laid down and the barrels are rolled onto these. The roof is covered with galvanized steel.

The upper room was originally intended only as a sorting room, the lower story being expected to hold all the fruit in storage. As a matter of fact, however, the upper room has several times been held full of 
apples for several montlis at a tine, with excellent success. A small stove is provided, and a trifling fire is kept on very cold day's, just to take the chill off the air. A temperature of about $26^{\circ}$ is the lowest ever registered during the storage season. The temperature generally maintained is $32^{\circ}$ to $35^{\circ}$.

The following bill of materials and labor shows approximately the cost of this house :

$$
\begin{aligned}
& \text { I,000 feet Joists, } 2 \times S \text {. . . . . . . . \$I } \$ 1.00 \\
& 600 \text { "Studding, } 2 \times 4 \text {. . . . . . . } 8.40 \\
& 5,000 \text { " Ceiling, matched spruce . . . . } 60.00 \\
& \mathrm{I}, 000 \text { " Flooring, hard . . . . . Is.00 } \\
& 500 \text { " Sills, } 6 \times 6 \text {. . . . . . . . . } 6.00 \\
& \text { I,000 ". Floor Covering . . . . . . . } 6.00 \\
& \text { Clapboards . . . . . . . } 1960 \\
& \text { ro Windows . . . . . . . } 15.00 \\
& \text { Io Window-frames . . . . . . . } \\
& \text { Paper. . . . . . . . } 10.00 \\
& \text { Lath and plaster . . . . . . } 12.00 \\
& \text { Roofing, galvanized steel . . . } 24.00 \\
& \text { Labor . . . . . . . . . } 125.00 \\
& \text { Incidentals, nails, etc. . . . } 30.00 \\
& \text { Total . . . . . . } \$ 358.00
\end{aligned}
$$

\section{NOTES ON VARIOUS STORAGE HOUSES}

This list of descriptions of storage houses with records of results might be continued to considerable length. It seems best, however, to draw it to a close with sundry notes on various storage houses in different parts of the country. Elach one of these houses has been a separate problem, and each man has worked the questions out for limself. All are therefore interesting, and more or less instructive. 
A Colorado house.-Hon. IW. S. Coburn, of Hotchkiss, Col., has a very successful house which is known all over the state. It is $36 \times 60$ feet, and one and a half stories high. It is built double, with two 8 -inch concrete walls having a $f$-inch dead-air space between. The lower floor is of cement with a board covering. The boards are laid three-quarters of an inch apart. The upper floor is carried by $2 \times 8$ joists. Strips are nailed on the lower edges of these, and inch boards are sawed and furred in between the joists, being nailed to the strips just mentioned. These furrings are then corered with heavy felt paper, and the spaces between the joists filled to the top with concrete. Another floor is laid on top of this, making the whole construction uncommonly sound and tight. There are ventilators at each end of the building to admit air from the outside. The apples are kept in bins, which seems to be customary in the western states. The bins have successive slat floors placed every 30 inches, one above another, and the fruit is spread on these. Over each bin there is a ventilator, which, in drawing off warm air, creates a draft through the apples in the bins. The temperature is controlled entirely by ventilators. Such control has been found entirely practicable and satisfactory.

More Colorado experience. - Another Colorado apple grower who has had much gratifying experience in storing fruit, particularly apples, is J. S. McClelland, of Fort Collins. His storage house is 70 feet long, varying in width from 12 to $\mathrm{I} 8$ feet, and holding about I, 500 barrels. This part is mostly under ground, and 
forms the chief storage. At one end there is a twostory frame packing house, $24 \times 24$ feet, the lower floor of which is also sometimes used for storage. The sides of the main storage room are of earth, and so are the floor and the roof. The apples are stored in tiers in bins, however, in the same manner employed by Mr. Coburn and described above. The temperature is controlled entirely by rentilation, and $\mathrm{Mr}$. McClelland tells me that he has successfully carried apples in this room till May. Mr. McClelland, it should be said, makes a specialty of Ben Davis, which he grows in great perfection, so that his stock is the very best for storage.

An Ontario house.-Brooks Brothers, of Courtice, Ontario, have a well-built and exemplary storage house, used almost altogether for apples. The building is at Oshawa Junction, and is built beside the railroad tracks conveniently for shipping. It has a capacity of 10,000 barrels. It is two stories high, built of stone below and woodwork above. The floors are of cedar plank. The temperature is controlled entirely by ventilation, there being neither artificial refrigeration nor heat applied. It has been successful.

An improvisation.-The house used by Mr. H. H. Hill, of Isle La Motte, Vt., for storing apples is of general interest from the fact that it was improvised from materials on hand. Mr. Hill made use of an old stone woodshed attached to the house, after the manner common in rural New England. The stone walls are 2 feet thick. The storage room proper is about $26 \times 32$ feet in size, and high enough. Planks 
were laid on the ground for the barrels to rest on. The apples are put into barrels as fast as picked and are taken directly to the storage room. Here the barrels are piled up one above another, standing on end and unheaded. They are allowed to remain undisturbed in this position till shipping time, when the

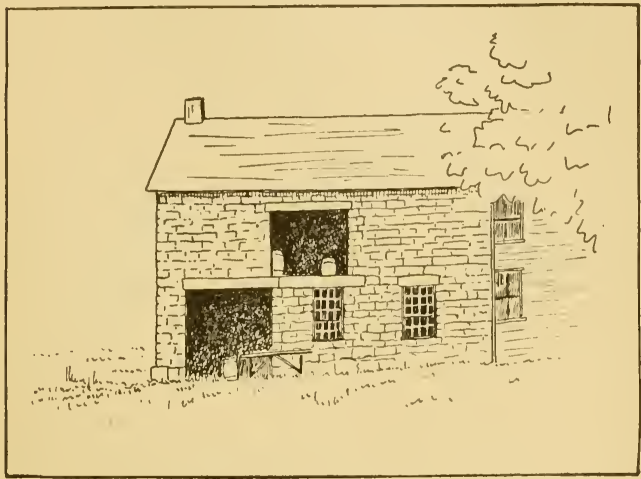

FIG. 48-WOODSHED CONVERTED INTO STORAGE HOLSE

fruit is resorted, packed, headed, marked, and sent to market. The house has been only fairly satisfactory, and Mr. Hill thinks he could improve it considerably by making some alterations in the light of his several years' experience.

A small home storage house.--A small storage house, holding fruit for home use only, is owned and operated by Mr. Joe A. Burton, of Orleans, Ind. This house holds 115 barrels of apples when quite full. 
It is I 1 X I 2 feet in size on the floor. It is built of brick with double walls, four inches apart, and filled with sawdust between. The ground floor is 15 inches below the surface of the ground, but the soil is banked up against the outside walls to some hight for protection. The room is 8 feet high inside. The ceiling is covered above with 15 inches of sawdust. The floor is grouted and cemented and the walls are plastered. This house has proven unusually successful for holding apples; but much of the good result is doubtless due to the manner of growing and handling the fruit. Mr. Burton writes me on this matter as follows: "Our success in keeping apples is due more to the handling than to the house; in fact, onr apples are kept in the barn and outhouses till cold weather drives them into the cellar. Did we barrel them as you state in your bulletin, only partially assorted, we would expect to lose nost of them, as do our 1reiglbors. Every apple showing any sign of decay is rejected. We leave then on the tree as lonig as possible, not to have too much loss by falling. They can pass the hot spells mucl more successsully on the trees than in the barrels. It is the hot weather after gathering, hastening the ripening, that causes most of the loss we sustain. We hardly know such a thing as winter rot. A cellar under a house is too warn to keep apples well in our climate. Our key to success is: Assort severely, and keep as cool as possible not to freeze."

West Virginia experience.--Certain counties of West Virginia produce considerable quantities of 
apples, and in these neighborhoods storage houses have been found very useful, The following notes of conditions and experience in West Virginia are made chiefly from information furnished by Professors L. C. Corbett and K. C. Davis.

There are in Hancock County six or seven houses varying in capacity from 2,500 barrels up to 35,000 . These houses are variously constructed of wood.

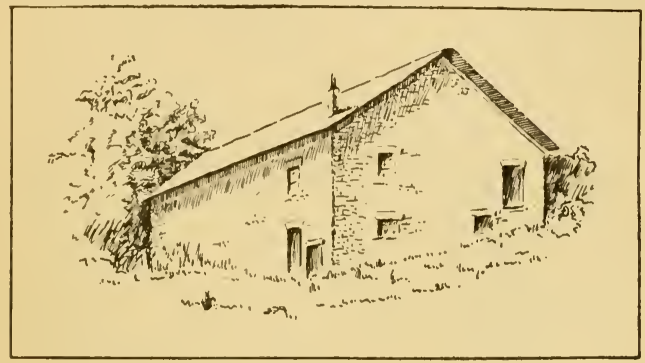

FIG. 49-WEST VIRGINIA APPLE HUUSF

brick, and stone-most of them, however, of stone. They are nsually placed on sloping land and built in the fashion of a bank barn, with a basement story and a story above ground. The basement story is frequently corered with soil on two or three sides, making a sort of a cellar. Some of these buildings are used merely as warehouses, while others are provided with an ice chamber, always on the second or third story. Where ice is used a metallic floor is provided for the ice chamber. The storeroom, besides having the stone wall, usually is to 24 inches thick, is 
I 52 FRUIT HARVESTING, STORING, MARKETING

also provided with a lining constructed of studding, building paper, and matched flooring. This makes a dead-air space 2 to 4 inches wide, according to the way the studding is placed between the wood and stone walls. A cement floor, or compacted earth floor, is provided in the basement room, and on top of this wooden trestles or a tight board floor is placed. If the floor be of compacted earth, wooden trestles are usually preferred, while in one of the best houses a tight board floor is used. The second story floor is usually built of $2 \mathrm{x} 4$ stuff, placed on edge, with an air space about an inch wide between each of the $2 \times 4$ 's. This provides for a complete circulation of air between the two stories. The fruit is usually packed tightly in barrels, without sorting, as it is taken from the trees. These are carried directly to the storerooms and packed away with the barrels on the side, as a rule, $\mathrm{I} \times \mathrm{x} 6$ pieces being used as a guideway between each tier of barrels. In this fashion the whole chamber is stored full of barrels from floor to ceiling. The fruit is not disturbed after being placed in the wareroom until it is packed out for shipment. Then it is graded and each barrel labeled according to the grade to which it belongs. Where ice is used the houses are iced before beginuing to store the crop, so as to have the storerooms cooled as the barrels are placed in permanent quarters. The growers seem to have an idea that this is a very essential part of the management of the house. Aftei getting the temperature once reduced it is maintained, as nearly constant as possible; in the neighborhood of $34^{\circ}$ to $38^{\circ}$. 
Mr. Arthur H. Hill's house.-The apple house of Mr. Arthur H. Hill, Isle La Motte, Vt., herewith illustrated, is an admirable example of what may be done without going to the expense of constructing a complete storage plant. The house was built merely for a packing shed, and this is still its chief use. It has, nevertheless, served as a storage house at a pinch, and its success in that line is worth noting. Mr. Hill

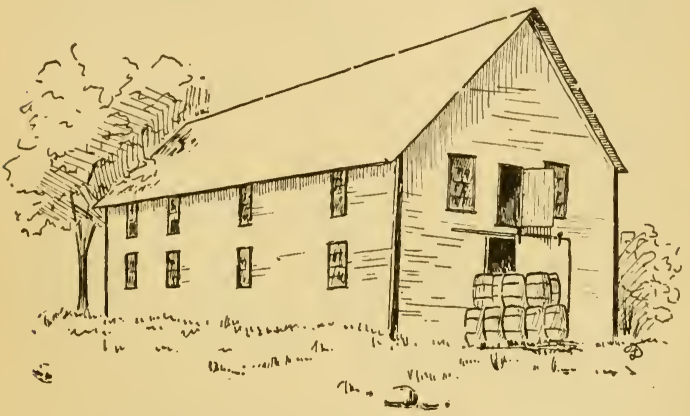

FIG. 50-CHEAPER HOUSE FOR TEMPORARY STORAGE

tells we that he has held apples successfully till the middle of February, and through a temperature of $18^{\circ}$ below zero, by the aid of a small wood stove in which an occasional fire was kinclled.

The walls of this house are not constructed with a view to keeping out the cold, being only one thickness of novelty siding. The floor below is of sand, on which boards are distributed thickly enough to keep the barrels clean. The second floor is of matched spruce, and is approached by a stairway in one corner. 


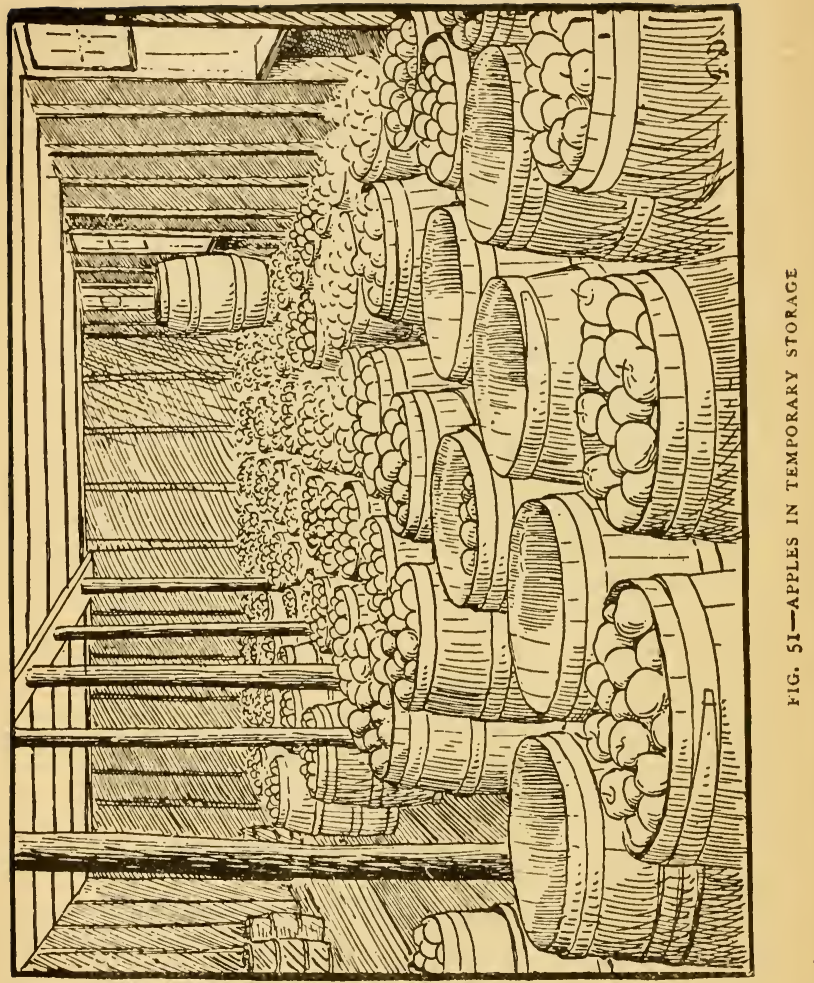


Large double door openings in each end-large enough to admit a team and wagon-are protected only by sliding doors of single thickness. There are four twosash windows on either side.

The house is $26 \times 65$ feet, with 15 -foot studs and a "quarter pitch" shingled roof. The total cost was about \$400.

Only the lower story has ever been used for storage. This will hold something over one thousand barrels of apples when full. The second story is used as a cooper shop, and for the storage of barrels, spraying apparatus, etc.

XVI. DHSIGN FOR SIMPLE LEAN-TO STORAGE

This design is intended to meet the requirements of the grower who has the smallest possible quantity of fruit to store. It will accommodate one hundred barrels of apples when full, but of course can be used equally as well for grapes, plums, or pears. It is to be constructed in the simplest and cheapest possible manner consistent with efficiency. It is to be built as a lean-to on the north side of some barn or granary already standing.

The dimensions inside are as follows: Length, 20 feet; breadth, 10 feet; hight, 8 feet. The rafters may be of $2 \times 4$ stuff. The roof should be shingled on top of two layers of inch boards, with building paper betiveen. On the under side of the rafters there should also be a ceiling of well-matched lumber, with a layer of building paper inside. The studs may also be of $2 \times 4$. Outside they should have a layer of inch pine boards carefully laid, a double coating of building 
paper, and a layer of novelty siding. Inside they should be covered with anotler layer of inch boarding, a layer, or, better, two, of builcling paper, and finally a

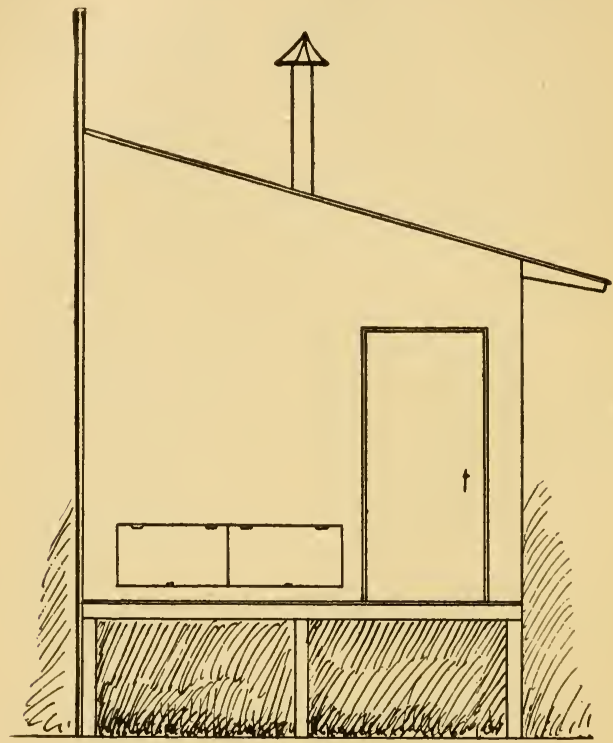

FIG. 52-LEAN-TO STORAGE HOUSE-END VIEW

good course of ceiling well laid and heavily painted. The sill should consist of one piece of $2 \times 4$ and one of $2 \times 6$ spiked together, L, sliaped, making a box sill. The joists should be $2 \times 6$.

There should be one door and no windows. In- 
stead of window's there should be rentilators along the side, put in just above the level of the floor, as shown in the end elevation in the figure. These can be lifted from the outside without disturbing the house, and cold air admitted as required. A ventilator for carrying off the warm air should be placed near the middle of the room, and may properly be made high enough above the roof to be somewhat independent of the building against which the lean-to storage house is constructed.

It n11ay or may not be convenient to have the floor of the storage room $2 \frac{1}{2}$ to 3 feet above the ground, so that barrels may be easily handled in and ont of a wagon. In case the high floor is preferred, a small unloading platform will be found a great convenience.

This liouse can be built for about $\$ 75$. On some farms where material can be had cheaply, and where the work can be done without hiring, it will not cost more than $\$ 50$. It ought to cost not more than $\$$ IOO anywhere.

XVII. DESIGN FOR COMMODIOUS HILLSIDE STORAGE

The ordinary way of building a storeroom into a hillside is to place the house lengthwise into the hill instead of lengthwise along the hill. Such a storage room is usually small, and the construction is properly a "dugout," or "cave," such as has already been described in this cliapter. A more commodions storage cellar may be made by rumning the room the other way, longitudinally along the hill-slope. This is the way in which the large and well-known storage house of the Olden Fruit Company is constructed. 
The storage house of the Olden Fruit Company, of Olden, Mo., is a pioneer in its way, and its success has been gratifying, on the whole. The manager writes me that they have held apples in good condition till the first of March-this in Missouri. The house is $192 \times 46 \times 12$ feet inside, and holds about

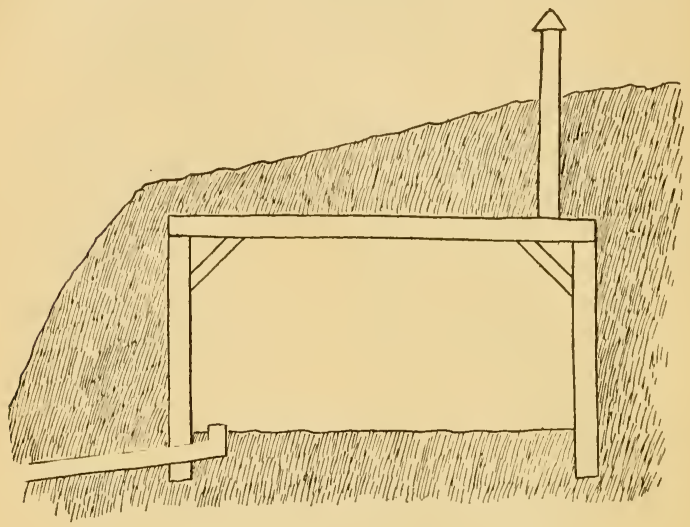

FIG. 53-CROSS SECTION OF HILLSIDE STORAGE

I 4, 000 barrels of apples. The house is not roofed with earth, but the soil which was taken out of the excavation was used to bank up on the lower side as high as the eaves. The roof is of boards battener. It has a pitch of forty-five degrees.

The house here suggested and show'n in section, Fig. 53, is considerably smaller, being only 6 feet high and 12 feet wicle inside. These dimensions, of 
course, may be varied to any extent and in any direction to suit the convenience of the builder. It may be made of any required lengtli.

The best method of construction would be to set posts along the sides in the place of studs. These should be of cedar, oak, catalpa, or otlier durable wood, and should be long enougl that they n1ay be inserted 2 or $21 / 2$ feet into post-holes at the bottom. They should be thoroughly tamped in and anchored

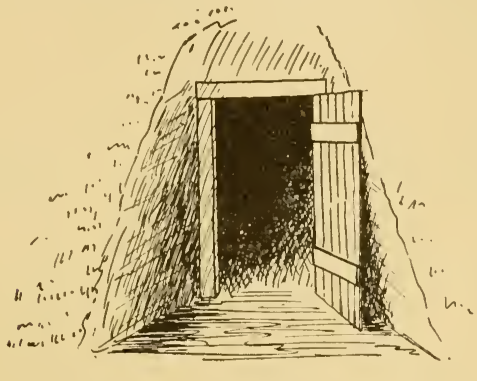

FIG. 54-ENTRANCE TO HILLSIDE STORAGF.

with stone. Heavy plates may be spiked to the tops of these posts. These plates should not be less than $3 \times 8$ inches-preferably more. Or box plates may be used, made of two pieces of $3 \times 8$ or $2 \times 8$ spiked together. Heavy joists will also be required, which should be spiked to the plates. If the stud-posts are numerous enough and properly placed, the joists can be spiked directly to them, which will be still better. If the earth roof is to be used, as it may properly be, the joists should be covered on top with a number of 
loose boards, then with light poles, then with some brush, and finally the earth may be drawn on with a scraper. The roof should be ceiled on the inside, preferably with matched 1 -inch lumber. This ceiling may be nailed directly to the stud-posts on the sides and to the joists overhead. It will be worth while, if opportunity offers, to fill in behind and above the ceiling with sawdust. A floor will not be required; but some loose planks should be laid on the ground for the barrels to re:t on.

One or more rentilators should be put in at the back of the room, as shown in the figure, extending up to the ground above. These will carry off the warm air when required. They should be arranged so as to be closed whenever desired. One ventilating shaft 16 inches square inside should be provided for each 12 feet in length of the storage room. On the opposite side of the storage room, and at the bottom, there should be a number of drains provided. These should be made of tile or similar materials. These drains should be laid in such a way as to serve also as inlets for cool air when required. They will thus act in conjunction with the warm-air outlets provided above and at the opposite side of the room. They should, like the warm-air drafts, be arranged so as to be closed and opened at will. Perhaps the best size for these combined drains and ventilators is six inches; that is, they will be of six-inch tile. There should be one such ventilator drain for every six feet in lengti of the house, or if there is apt to be much seepage water to be carried off, the drains should be larger or more numerous. 
The door to this house vill naturally be made in the side, and may be located either at one end or in the middle, as may best stit the builder. A proper vestibule slould be built about it, or two doors should be used, the one to protect the other. Window's may be introduced on the down-hill side of the room if thought necessary, but they would probably be more trouble than use.

The cost of such a house would vary immensely according to the manner in which it were built. The

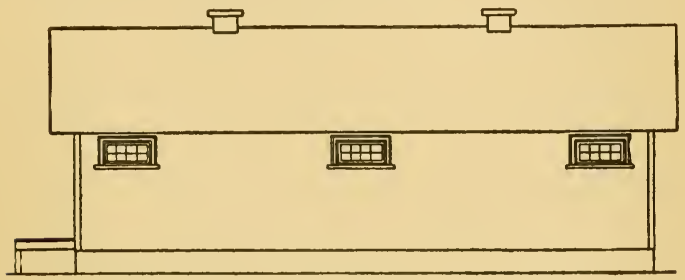

1. IG. 55-SIDE ELEVATION OF STORAGE HOUSE

chief expense would be for labor ; and this is often an item of small expense on the farm. If all the labor had to be hired the expense would naturally be more serious. It is impossible, however, to make any estimate of the cost here.

\section{DFSIGN FOR A THOUSAND-BARREL, STORAGE HOUSE}

The design herewith given was contributed by the author to Country Gentlemen, December 7, 1899, and is here reproduced with new illustrations. The plan is intended to provide an apple storage house with a 
I62 FRUIT HARVESTING, STORING, MARKETING

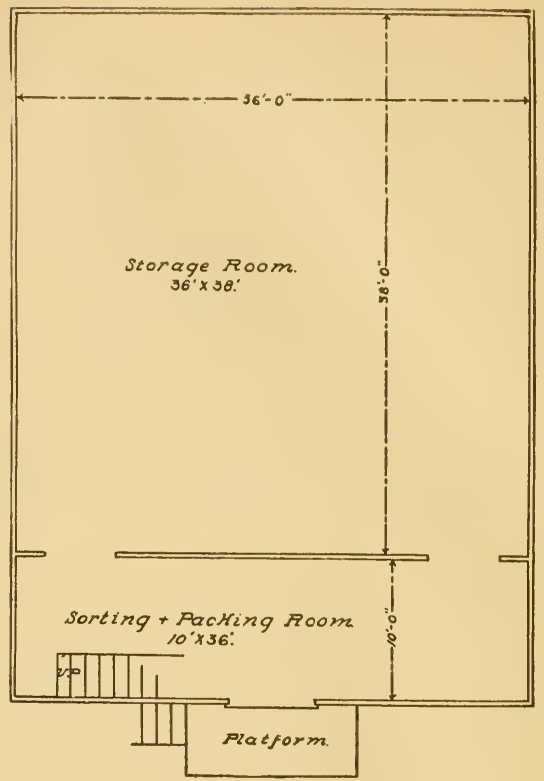

FIG. 56-PLAN OF STORAGE HOUSE

capacity of I, ooo barrels, to be built in one story on level ground.

The main storage room of this house is $36 \times 3^{8}$ feet, and will hold just about $i, 000$ apple barrels when full. They will then be piled up three tiers high, which is not an inconvenient arrangement. Apple growers have generally found it best to store apples in 
barrels. The house also has a sorting and packing room $10 \times 36$ feet, all of which space will be needed. This packing room stands next to the outside door, and the only entrance to the storage room is through this sorting room. This protects the storage room from outside temperatures, and permits work to go on, either bringing in fruit or taking it out, without disturbing seriously the atmosphere in the storage room.

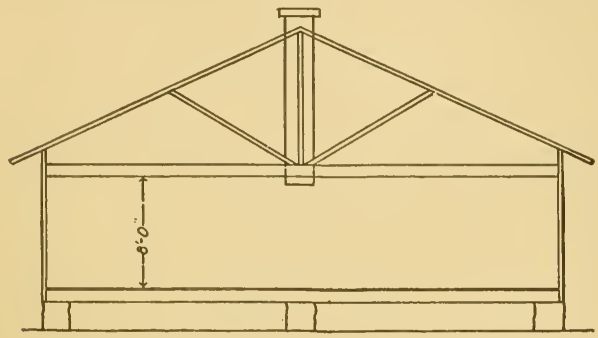

FIG. 57-SECTION OF STORAGE HOLSE

The space overhead will be needed for storing barrel stock, etc.

The front (double sliding) door should be 6 feet wide, and the two. inside doors should be 3 feet 6 inches. It will be an advantage to have two inside doors, arranged as shown in the plan. If a single door is used between the two rooms and is put in the middle of the partition, it will admit more drafts of outside air to the storage room, and will not be so convenient in handling barrels from one room to the other.

No ice or artificial refrigeration is needed in this 
house-at least, not for any place north of Virginia. The temperature can be easily controlled by the windows and the ventilators shown in the various elevations. With the windows placed high up on the sides, as shown in the elevation, Fig. 55, it will be desirable to have guides placed inside the windows at a distance of 6 to 8 inches in front of them, and extending 2 or 3 feet lower than the bottoms of the windows,

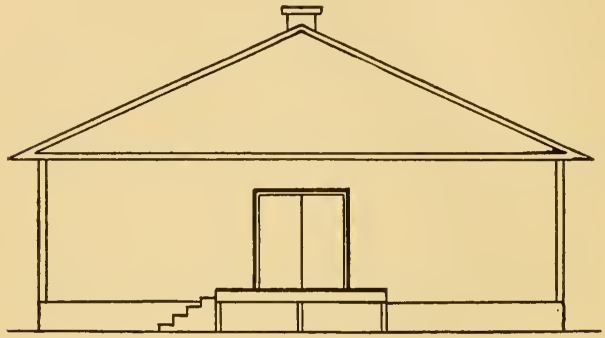

FIG. 58-END ELEVATION OF STORAGE HOUSE

to deflect the cool air downward as it enters. Otherwise the entire circulation will be in the upper part of the room while the air will become stagnant near the floor.

The walls should be double thick. Inside they should be boarded with matched lumber on the studs, and then closely ceiled on top of this. The ceiling should also be heavily painted. This is absolutely essential. Outside they should have a sheathing of inch lumber and a coat of building paper on top of this, the whole to be covered with matched novelty 
siding. This may seem a good deal of material to put into the walls, but it will pay. Still, one or two layers may be onitted " at the owner's risk."

This house will cost from $\$ 800$ to $\$ 1,200$, depending on who builds it, and where.

Details of construction, such as ventilation, formation of the walls, etc., may be varied to suit the needs and notions of the builder.

XIX. SPECIAL DESIGN FOR ARTHUR H. HILL

Mr. Arthur H. Hill, of Isle La Motte, Vt., projects an apple storage house of a somewhat novel type, to suit rather unusual conditions. $\mathrm{He}$ has an old stone quarry just on the bank of Lake Champlain. The stone has been taken out in such a manner as to leave a perpendicular wall a little over twenty feet in hight facing the lake. He proposes to build the storage house against the face of this rock wall, thus saving the construction of the west wall of his storage house. The other three walls will be built of stone taken from the quarry on the spot.

The site has two other natural and unusual advantages. The position on the very shore of the lake makes it easy to secure a supply of ice, and the plan is to use ice in cooling the fruit rooms. In the second place, the apples are often shipped by boat, and a dock can easily be provided within a few feet of the building, so that barrels can be loaded directly out of the house and into the boat. Canal boats run directly from this point to New York and Buffalo, so that marketing is attended with the utmost conrenience. 


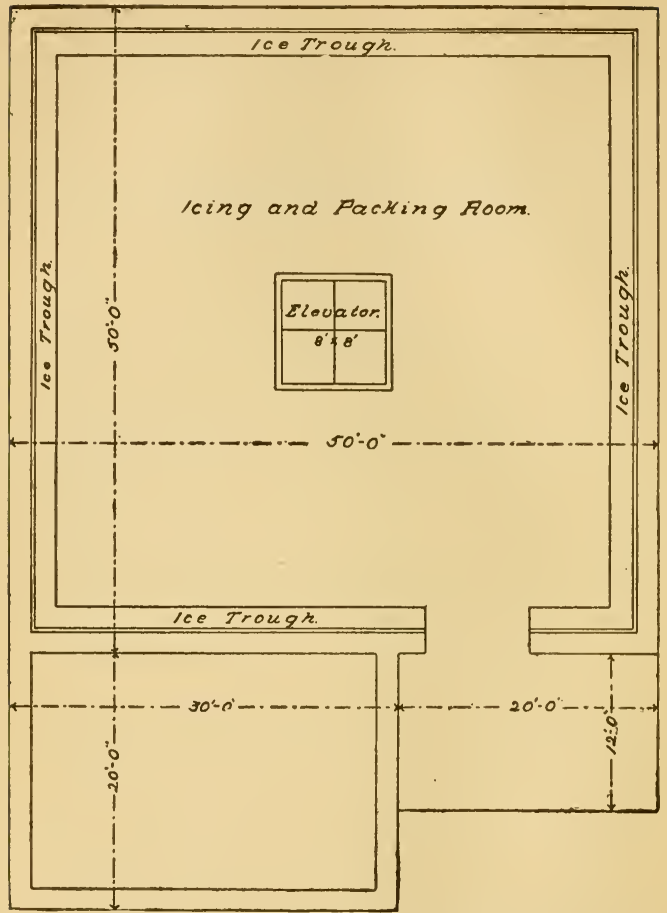

FIG. 59-PLAN OF STORAGE HOUSE FOR MR. ARTHUR H. HILL

The proposed plan, shown herewith, calls for a building 50 feet square, and 24 feet high to the eaves, with four stories and a garret. Each story of the 
storage space proper is made low, only $6 \frac{1}{2}$ feet between floor and ceiling. This will accommodate two tiers of barrels on end, and, in case of crowding, another tier on the side. This makes less work in handling than when barrels are piled three tiers high,

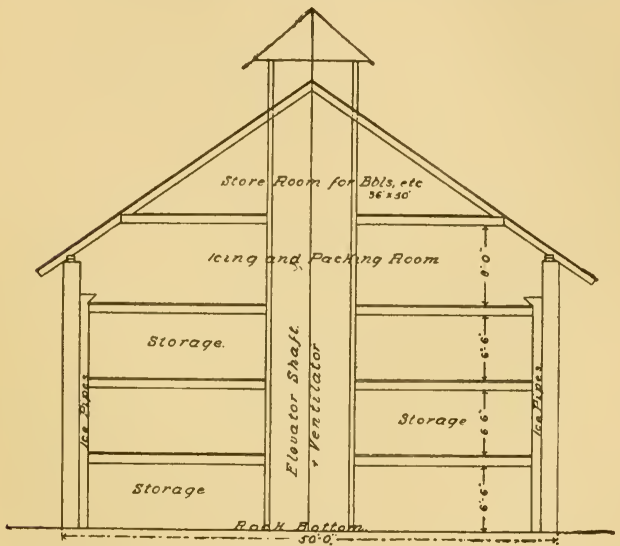

FIL. GO-SECTION OF PROPOSED ICE-COOLEN STORAGE-HOUSE:

and there is consequently less rough handling of the fruit.

In the center is a shaft $S \times \mathrm{S}$ feet in size, which serves the triple purpose of elevator, rentilator, and support for the floors. This will be open on all four sides, but with doors arranged so as to control ventilation when necessary. 
The upper floor-the one opening on the bankwill be used as a packing room. The fruit will be received here, and may be discharged either from here or from the lower story. This room will be used also for icing the pipes in cooling the rooms below.

The system of ice cooling proposed is that already described, page ı 3 . Pipes of galvanized iron 8 inches in diameter will extend from the icing trongh on the upper floor to the waste trough on the lower floor. These can be filled with the crushed ice and salt mixture when desired. If only a part of the storage space is in demand, the lower room will be cooled by filling the tubes as high as the ceiling of that room.

The necessary ice house will be built against the storage house, probably on the edge of the bluff above, and on a level with the floor of the icing room.

A lining of rongh sheathing will be used between the stone wall and the cooling pipes, and another lining or curtain of lighter material will be placed inside the range of pipes. Other details of construction have not yet been determined on, but will be sufficiently obvious so that any practical builder can follow the general outlines of this plan and make the necessary adaptations nnder any circumstances which make a similar constrnction seem desirable. 
PART SIX

Appendix 



\section{A P P E N D I X}

\section{IMPORTS AND EXPORTS OF FRUIT, UNITED STATES}

The following tables, showing the imports and exports of fruits, are taken directly or indirectly from the reports of the Secretary of the Treasury of the United States. Those indirectly secured come by way of a paper prepared by Mr. W. A. Taylor for the United States Department of Agriculture Year Book, I 897. page 305. This important article has not attracted the attention it deserves. It brings out, by means of statistics and text, the interesting fact that homegrown fruits are being rapidly substituted for foreigngrown fruits of many kinds. This condition is further established by the additional statistics given below.

Take, for example, the items of raisins and prunes. The importations of these fruits increased steadily and enormously from i 830 up to 1890 , but from that time have fallen off quite remarkably. This is due, of course, to the establishment of the raisin grape industry in California and of large prune orchards all along the western coast. In this direct connection there should be noted the other fact that, while importations have been greatly reduced, the United States has actually 
I 72 FRUIT HARVESTING, STORING, MARKHTING

opened a considerable export trade in these same fruits, as will be seen from these figures :

EXPORTS OF RAISINS AND PRUNES, 1898-1900

\begin{tabular}{|c|c|c|c|c|}
\hline \multirow{2}{*}{$\begin{array}{l}\text { VEAR ENDING } \\
\text { DECEMBER }\end{array}$} & \multicolumn{2}{|c|}{ RAISINS } & \multicolumn{2}{|c|}{ PRUNES } \\
\hline & Pounds & Dollars & Pounds & Dollars \\
\hline $1898 \ldots \ldots$ & $4,50 \pi, 084$ & 222,975 & $8,164.98 \pi$ & $53 \pi, 628$ \\
\hline $1899 \ldots$ & $3,554,920$ & 204,001 & $16,519,024$ & $1,048,453$ \\
\hline $1900 \ldots \ldots$ & $3,542,8 \pi 5$ & 217,502 & $16,632,803$ & $1,031,946$ \\
\hline
\end{tabular}

The increasing importance of the American prune industry may be better judged by the fact that the output has doubled within the last five years. The California prune crop, which forms the bulk of the output, has, during the last half decade, reached the figures given herewith.

\section{- pRUne output of california}

\begin{tabular}{|c|c|c|c|c|c|}
\hline $\begin{array}{l}\text { Year } \\
\text { I } \$ 96\end{array}$ & & $\begin{array}{c}\text { Pounds } \\
55,200,000\end{array}$ & $\begin{array}{l}\text { Year } \\
\text { I } 898\end{array}$ & & $\begin{array}{c}\text { Pounds } \\
90,420,000\end{array}$ \\
\hline & $\cdot \dot{\text { I9OO }}$ & $\begin{array}{r}97,780,000 \\
(\text { estimated) }\end{array}$ & & $\dot{125,0}$ & $\begin{array}{l}\text {. } \mathrm{II}_{4}, 227,000 \\
0 \mathrm{O}, 000\end{array}$ \\
\hline
\end{tabular}

Such fruits as olives, pineapples, bananas, and dates, not commercially produced in the United States, are imported every year in larger and larger quantities. The whole fruit trade is increasing enormously every year, so that any reduction in importations almost necessarily means a larger increase in domestic production.

With these remarks the following tables are submitted. 
AVERAGE ANNUAL, IMPORTS OF FRUITS INTO THE UNITED STATES BY DFCADES, IN POUNDS

\begin{tabular}{|c|c|c|c|c|c|}
\hline $\begin{array}{l}\text { DECADE } \\
\text { ENDING }\end{array}$ & Raisins & Currants & $\begin{array}{c}\text { Plums and } \\
\text { Prunes }\end{array}$ & Dates & Almonds \\
\hline 1830 . & $4,43 \pi, 939$ & 189,523 & 146,929 & 44,426 & $63 \pi, 866$ \\
\hline 1810 & $13,203,732$ & $489, \pi+\pi$ & 584,969 & $429,3 \mathrm{n}$ & $2,240,451$ \\
\hline 1850 . & $13,492,060$ & $1,33 \mathrm{I}, 63 \mathrm{i}$ & $398,+22$ & 362,227 & $1,498.692$ \\
\hline 1860 & $19,00 \times, 255$ & $3,176,469$ & $3,833,635$ & $1,553,679$ & $3,352,759$ \\
\hline $18 \% 0$. & $21,468, \pi 83$ & $5,866,839$ & $6,333,581$ & 1. 118.348 & $2.290,157$ \\
\hline 1880 . & $33, \pi 31,861$ & $16,491, \tau 2 \tilde{z}$ & $25,108,911$ & $4,059,331$ & $2,514,0 \div 2$ \\
\hline 1890 . & $41,812,016$ & $28,189,0 \pi 4$ & $56.928,640$ & $8,884,713$ & $3,121,444$ \\
\hline $1890-9 \%$. & $18,4 \tau 3,610$ & $34,505,448$ & $14,323,463$ & $15,193,490$ & $3,500,835$ \\
\hline
\end{tabular}

ANNUAL, IMPORTS OF FRUITS INTO THE UNITED STATES FOR TEN YEARS, IN POUNDS

\begin{tabular}{|c|c|c|c|c|c|c|}
\hline YEAR & Raisins & Currants & $\begin{array}{c}\text { Plums and } \\
\text { Prunes }\end{array}$ & Figs & Dates & $\begin{array}{c}\text { Al- } \\
\text { monds }\end{array}$ \\
\hline 1891 & $37,1 \sim 4,1<6$ & $42,849,814$ & $41,012,5 \pi 1$ & $9,063,663$ & $20,091,012$ & 3,390 \\
\hline 1892 & 18,$8 ; 3,690$ & $36,665,728$ & $10,374,864$ & $8,324,861$ & $17,089,367$ & 3.451 \\
\hline 1893 & $23,598,985$ & 33.166 .364 & $23,225,821$ & $10.060,092$ & $16,248,515$ & 2,780 \\
\hline 1894 & $13,660,498$ & $52,350,083$ & $8,749,349$ & $7,930,316$ & $12.408,409$ & 3,305 \\
\hline 1895 & $13,888,095$ & $15,936,019$ & $15,311,695$ & $11,559,092$ & $14,716,765$ & 4,17 \\
\hline $1 \times 96$ & $10,202,086$ & $32,351,985$ & 852,944 & $11,635,493$ & $13,5 \pi 5,254$ & 3,202 \\
\hline 1897 & $11,917, \pi 56$ & $28,218,176$ & $\tau 36,987$ & $8,83 \tilde{1}, 5 \div 2$ & $12,225,111$ & 4,196 \\
\hline 1898 & $5,386,1 \pi$ & $34,061.006$ & 613,887 & $7,992,554$ & $12,346,466$ & \\
\hline 1899 & $9,651,910$ & $32,244,832$ & 450,591 & $8,535,96 \pi$ & $16,061,736$ & \\
\hline 1900 . & $4,332,040$ & $20,578,082$ & $\tau 29,611$ & $9,508,064$ & $20,550,435$ & \\
\hline
\end{tabular}

EXPORTS OF FRUITS FROM THE UNITED STATES FOR TEN YEARS

\begin{tabular}{|c|c|c|c|c|c|c|c|}
\hline \multirow{2}{*}{$\begin{array}{c}\text { YEAR } \\
\text { FND- } \\
\text { ING } \\
\text { JENE } 30\end{array}$} & \multicolumn{2}{|c|}{$\begin{array}{l}\text { APPLES, GREEN - } \\
\text { OR RIPE }\end{array}$} & \multicolumn{2}{|c|}{ APPLES, DRIEI } & \multirow{2}{*}{$\begin{array}{c}\text { CANNED } \\
\text { FRUTTS } \\
\text { Value }\end{array}$} & \multirow{2}{*}{$\mid \begin{array}{c}\text { ALL } \\
\text { OTHER } \\
\text { PRES'D } \\
\text { FRUITS } \\
\text { J'alue }\end{array}$} & \multirow{2}{*}{$\begin{array}{c}\text { ALL } \\
\text { OTHER } \\
\text { FRUITS }\end{array}$} \\
\hline & Barrels & lalue & Pounds & Value & & & \\
\hline 1890 & 453,506 & $\$ 1,231,436$ & $20,861,462$ & $\$ 1,038,682$ & $\$ 698,321$ & $\$ 59.401$ & $\$ 1.003,846$ \\
\hline & & $476,89 \pi$ & 6,$9 ; 3,1$ & & & 93,496 & 699.798 \\
\hline 1892 & $938,7+3$ & $2,407,956$ & $26,042,0 t$ & $1,288,1$ & $1,556,820$ & $214, \pi 38$ & $1,095,8$ \\
\hline 1893 & 408,014 & $1,09 \pi, 96 \pi$ & $\gamma, 966,81$ & $48: 2,0$ & $1,13 \%, 660$ & $2 * 2,381$ & 881,804 \\
\hline 189 & 78,580 & 242,617 & $2,846,6$ & 168, & 660,723 & 211,215 & $1,016,3$ \\
\hline 1895 & $818, \pi 11$ & $1,954,318$ & $\tau, 08,5,046 ;$ & 461,2 & $8 \pi 1,465$ & 47,420 & $1,522,100$ \\
\hline 189 & 360,00 & 980,289 & $26.691,9463$ & $1,340,5$ & 1,$3 ; 6,2 \times 1$ & $\tilde{6} 0,353$ & $1,868,850$ \\
\hline 189 & $1,503,9 \times \tilde{i}$ & $2,3 \pi 1,143$ & $30, \pi \tau 5,4111$ & $1,340,159$ & $1,6 \times 6, \tilde{1} 23$ & 43. 276 & $2,1 \approx 2,199$ \\
\hline & $60.5,390$ & $1,684, \pi 1$ & $31,031.254$ & 605.3 & & 82,504 & $3,562,191$ \\
\hline 1899 & 384,22202 & $1,210,4,9$ & 19.305, , 139 & $3 \times 1,2$ & $2,3: 30,715$ & 66,899 & $2,903,429$ \\
\hline 1900 & 526,636 & $1,414,655$ & $34,964,010$ & $2,247,8,51$ & $3,122,8: 31$ & $62,3 \% 0$ & $4,598,295$ \\
\hline
\end{tabular}




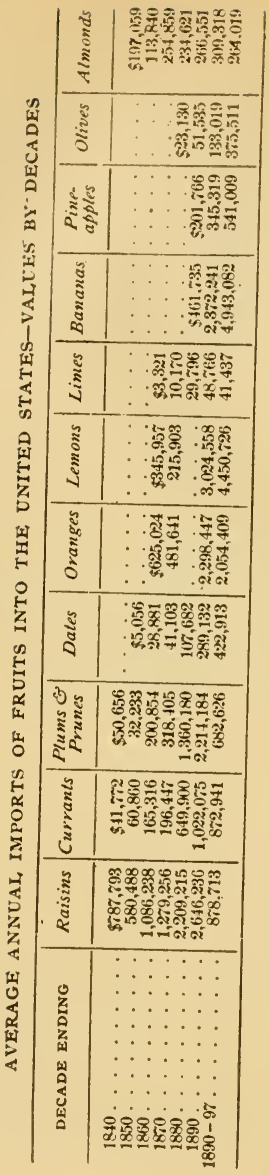

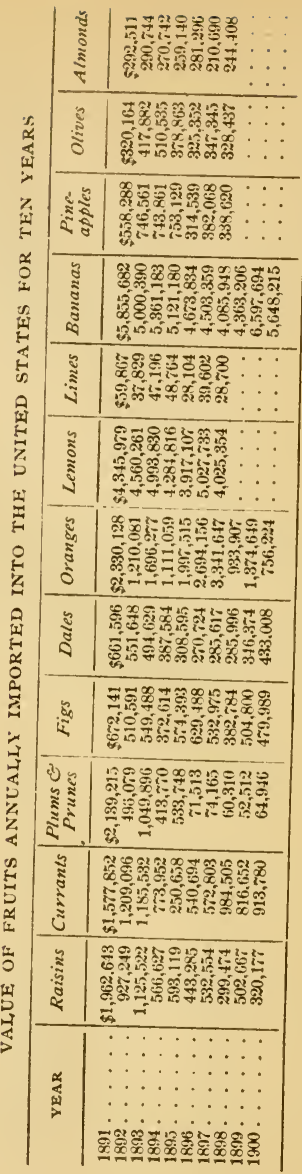




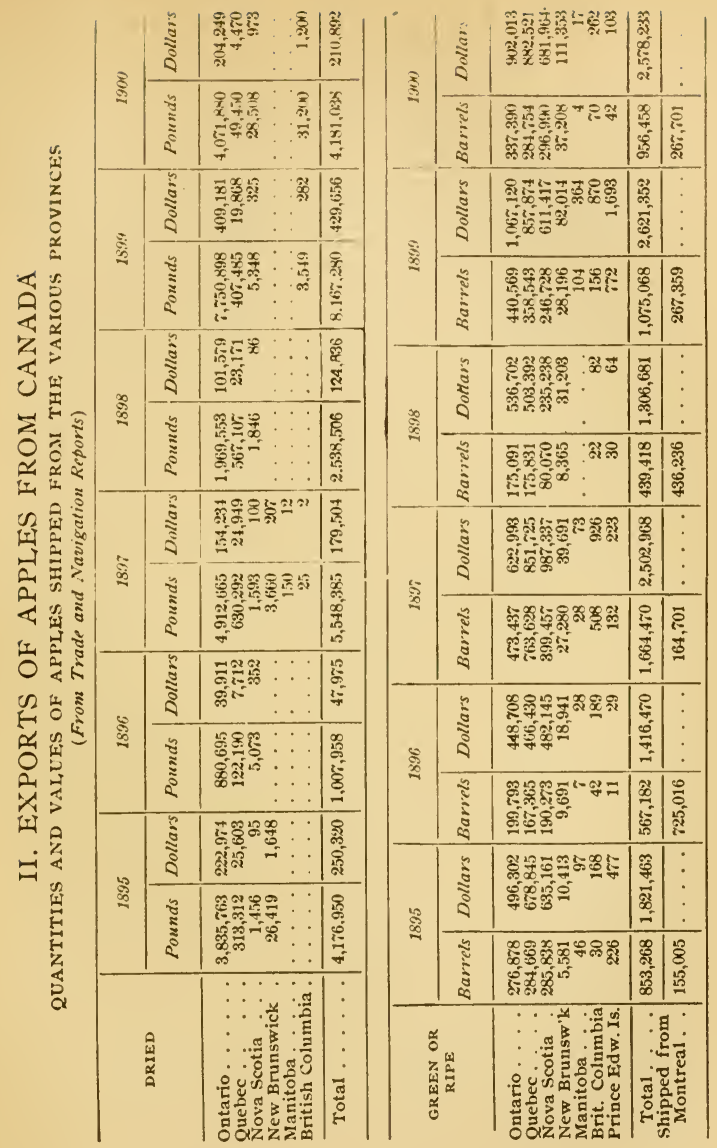




\section{STATE FRUIT-PACKAGE IAWS}

The writer is unable to say witl certainty that the fruit-package laws transcribed below are the only ones on the statute books in the United States and Canada; but he has carefully looked after all the states likely to have such laws, and these are all that can be found. Even these are mostly moribund. The Missouri applebarrel law, for instance, is entirely unknown to many of the best horticulturists in that state. Some of whom inquiry was made said there was no fruit-package law in existence in Missouri. In no state in the Union is one of these laws enforced.

In fact a study of the laws themselves would give the entirest stranger the feeling that they were not seriously intended. Most of them have a manifestly perfunctory air about them. In most cases no adequate provision is made for their enforcement. In New York, for instance, no one is charged with the enforcement of the law. A man who considers himself defrauded by short packages may bring action under the law, but he must do so at his own expense and risk.

It seens to the writer that the practicability of a fruit-package law-at least, in the United States-may be seriously questioned. There is no denying that anything which would tend to secure greater uniformity of packages, or which would tend to decrease fraudulent packing, would be a good thing. But considerable machinery would be required to make sncli a law effective; and after it was all arranged it would be harder to operate the nachinery than to avoid the trouble itself. 
At any rate, the laws now on the statute books seem to he highly insufficient. The course of future legislation can not be predicted, of course, but it is hardly likely that sufficient discontent will arise under the present organization of the fruit trade to give the force necessary to pass any new law stringent enough to count for much.

Following are the laws which have been found unrepealed. Most of them are of comparatively recent date.

\section{THE NEW YORK SMALL-FRUIT PACKAGE LAW}

The New York small-fruit package law (chap. 509 , laws of 1899 ) is as follows:

An Act to define the size of small-fruit packages. Became a law May 3, I899, with the approval of the Governor. Passed, three fifths being present.

The People of the State of New Iork, represented in Senate and Assembly, do cnact as follow's:

SECTION I. Small-fruit packages. - The standard of measures for buying and selling strawberries, raspberries, blackberries, currants, gooseberries, and other small fruits, shall be the quart, which shall contain when even full sixty-seven cubic inches; the pint when even full shall contain thirtythree and one-half cubic inches; the half-pint, which, when even full, shall contain sixteen and three-quarter cubic inches.

SEc. 2. Marks on baskets.-All manufacturers of smallfruit packages, such as quarts, pints, and half-pints, that make or cause to be made such packages that are of less size or capacity than the standard sizes as defined in Section $I$ of this Act, shall mark each such quart, pint, and half-pint with the word "short" on the outside in letters not less than onehalf inch in hight. 
Sec. 3. Penalty.- Iny person in this state who sells or offers to sell fruit packages that are of less than the standard sizes and capacity as defined in Section 1 , or any person who sells or offers for sale fruit in packages that are of less size or capacity than those defined in Section 1, that are not marked with the word "short," as directed in Section 2, shall be deemed guilty of a misdemeanor, and upon conviction thereof in any court of competent jurisdiction shall be fined not less than five dollars and not more than twenty-five dollars, and shall stand committed to the county jail until such fine and costs are paid.

SEC. 4. This Act shall take effect January first, nineteen hundred.

NEW YORK APPLE, PEAR, QUINCE, AND POTATO BARREL, I,A W

$$
\text { (Laws of 1899, chap. 317.) }
$$

An Act to amend the domestic commerce law in relation to the size of apple, pear, quince, and potato barrels.

The People of the State of New York, represented in Senate and Assembly, do enact as follows:

Section 1. Section nine of chapter three hundred and seventy-six of the laws of eighteen hundred and ninety-six, entitled "An act relating to domestic commerce law, constituting chapter thirty-four of the general laws," is hereby amended to read as follows:

SEC. 9. Barrels of apples, quinces, pears, and potatoes.-A barrel of pears, quinces, or potatoes shall represent a quantity equal to one hundred quarts of grain or dry measure. A barrel of apples shall be of the following dimensions: head diameter, seventeen and one-eighth inches: length of stave, twenty-eight and one-half inches: bulge, not less than sixty. four inches outside measurement. Every person buying or selling apples, pears, quinces, or potatoes in this state by the barrel shall be understood as referring to the quantity or size of the barrel specified in this section, but when potatoes are 
sold by weight the quantity constituting a barrel shall be one hundred and seventy-four pounds. No person shall make, or cause to be made, barrels holding less than the quantity herein specified, knowing or having reason to believe that the same are to be used for the sale of apples, quinces, pears, or potatoes, unless such barrel is plainly marked on the outside thereof with the words "short barrel". in letters of not less than one inch in hight. No person in this state shall use barrels hereafter made for the sale of such articles of a size less than the size specified in this section. Every person violating any provision of this section shall forfeit to the people of the state a sum of five dollars for every barrel put up made or used in violation of such provision.

SEc. 2. This act shall take effect immediately.

\section{MASSACHUSETTS BERRY-BASKET LAW}

Late in the spring of I gor the Massachusetts legislature passed the following law :

An Act relative to the size of berry baskets.

Be it enacted by the Senate and House of Representatives in Generai Court assembled, and by the authority of the same, as follows:

Sections one and two of chapter three hundred and thirtynine of the acts of the year nineteen hundred are hereby amended to read as follows:

Section I. Every basket or other receptacle containing one quart or less, used or intended to be used in the sale of strawberries, blackberries, cherries, currants, and gooseberries, shall be of the capacity of one quart, one pint, or onehalf pint, Massachusetts standard dry measure.

SEc. 2. Whosoever sells or offers for sale any such basket or other receptacle, containing one quart or less, not conforming to said standard to be used in the sale of any of the aforesaid fruit, and whoever sells or offers for sale any of the aforesaid fruit in any such basket or other receptacle, containing one quart or less, not conforming to the said stand- 
ard, shall be punished by a fine of not less than five dollars nor more than ten dollars for each offense.

\section{DELAWARE}

Section 22 of chapter 2 I 6 of the laws of Delaware, relating to the State Board of Agriculture, deals with the subject of fruit packages. The text follows:

The said Board of Agriculture shall have power to compel all growers of fruit to stamp or mark the baskets, boxes, packages, crates, parcels, or other receptacles used by them for the shipment of any fruit or fruits, with his, her or their name or names, initial or initials, or with some distinguishing device or mark which may be readily and easily read and seen on the same; and said Board may adopt rules and regulations to carry this into effect. If any grower of any fruit or fruits shall neglect or fail, after ten days' notice of said Board to comply with the provisions of this section, he or she or they shall be guilty of a misdemeanor, and upon conviction thereof shall forfeit and pay a fine of five dollars. - From Bulletin No. I, Deluware State Board of Agriculture, April 16, 1901.

\section{NEW JERSEY PEACH-BASKET LAW}

An Act for the protection of peach growers in the State of New Jersey, and to prevent deception in the size of peach baskets. Approved March 23, I892.

SEction I. That the standard size of peach baskets in the State of New Jersey shall be sixteen quarts Winchester half-bushel measure; that the height of the basket shall be twelve and one-quarter inches, and that the width across the top shall be thirteen and one-half inches, and that the inside measurement shall contain one thousand and seventy-five and ten one-hundredths cubic inches, and that such basket shall be marked "Standard, N. J.," upon the staves just below the rim in Roman letters, which shall be burned on or printed thereon with permanent red paint in a straight line, and each 
of them shall not be less than one inch in length, and not less than one-half inch in width, and that every person who shall manufacture for sale, or who shall offer or expose for sale any basket to be used for shipping or selling peaches not standard, shall distinctly and durably stamp, brand or mark upon such basket upon the stave just below the rim the number of quarts such basket contains.

Sec. 2. That every person who shall manufacture, sell, or offer or expose for sale, or have in his or her possession with intent to sell, or to use any peach basket or baskets not stamped, branded or marked as required by the first section of this act to be stamped, branded or marked, shall for every such offense forfeit and pay a fine of not less than twentyfive doiiars, and not more than fifty dollars, to be recovered with costs, in any of the courts of this state having cognizance thereof, in any action to be prosecuted by any prosecuting attorney in the name of the state, and the one-half of such recovery shall be paid to the informer, and the residue shall be applied to the support of the poor in the county where such recovery is had.

Sic. 3. That all acts and parts of acts inconsistent with this act be and the same are hereby repealed, and this act shall take effect the first day of September, one thousand eight hundred and ninety-two.

\section{MISSOURI APPLE-BARREL LAW}

The Missouri apple-barrel law (Mo. R. S. I899, Section 10,576$)$ is as follows :

Whenever apples shall be sold by the barrel. and no special agreement is made as to the size of the barrel by the parties, the size shall be as follows: Length of barrel, twentyeight and one-half inches ( $281 / 2)$, with chines of three-fourths of an inch at the ends; the diameter of the heads shall be seventeen and one-fourth inches ( $\left.17 \frac{1}{4}\right)$, and the diameter of the center of the barrel inside shall be twenty and one-half inches $(201 / 2)$. 


\section{CANADIAN I'RUIT-PACKAGE LAW}

Chapter 26, sections 4 and 5, of the statutes of Igor, Dominion of Canada, make the following provisions :

SeCtion 4. (I) All apples packed in Canada for export for sale by the barrel in closed barrels shall be packed in good and strong barrels of seasoned wood having dimensions not less than the following, namely: twenty-six inches and onefourth between the heads, inside measure, and a head diameter of seventeen inches, and a middle diameter of eighteen inches and one-half, representing as nearly as possible ninetysix quarts.

(2) When apples, pears, or quinces are sold by the barrel, as a measure of capacity, such barrel shall not be of lesser dimensions than those specified in this section.

Every person who offers or exposes for sale, or who packs for exportation, apples, pears, or quinces by the barrel, otherwise than in accordance with the foregoing provisions of this section, shall be liable, on summary conviction, to a penalty of twenty-five cents for each barrel of apples, pears, or quinces so offered or exposed for sale or packed.

SEC. 5. (I) Every box of berries or currants offered for sale and every berry box manufactured and offered for sale in Canada shall be plainly marked on the side of the box, in black letters at least half an inch square, with the word "Short," unless it contains when level-full as nearly exactly as practicable-

(a) at least four-fifths of a quart, or

(b) two-fifths of a quart.

(2) Every basket of fruit offered for sale in Canada, unless stamped on the side plainly in black letters at least threequarters of an inch deep and wide, with the word "Quart" in full, preceded with the minimum number of quarts, omitting fractions, which the baskets will hold when level-full shall 
contain, when level-full one or other of the following quantities:-

(a) fifteen quarts or more;

(b) eleven quarts, and be five and three-quarter inches deep, perpendicularly, inside measurement, as nearly exactly as practicable;

(c) six and two-thirds quarts, and be four and five-eighths inches deep, perpendicularly. inside measurement, as nearly exactly as practicable; or

(d) two and two-fifths quarts, as nearly exactly as practicable.

(3) Every person who neglects to comply with any provision of this section, and any person who sells or offers for sale any fruit or berry boxes in contravention of this section, shall be liable, on summary conviction, to a fine of not less than twenty-five cents for each basket or box so sold or offered for sale.

(4) This section shall come into effect on the first day of February, one thousand nine hundred and two.

\section{CANADIAN FRUIT MARKS ACT OF I9OI}

Chapter 27, statutes of I90I, assented to May 23, I 9or, makes the following provisions:

1. This Act may be cited as The Fruit Marks Act, I9or.

2. This Act shall come into operation on the first day of July, Igor.

3. In this Act, unless the context otherwise requires:-

(a.) The expression "closed package" means a box or barrel of which the contents cannot be seen or inspected when such package is closed;

(b.) The expression "fruit" shall not include wild fruit, nor cranberries whether wild or cultivated.

4. Every person who, by himself or through the agency of another person, packs fruit in a closed package, intended for sale, shall cause the package to be marked in a plain and indelible manner, before it is taken from the premises where it is packed,- 
(a.) with the initials of the Christian names, and the full surname and address of the packer;

(b.) with the name of the variety or varities; and

(c.) with a designation of the grade of the fruit.

5. No person shall sell, or offer, expose, or have in his possession for sale any fruit packed in a closed package and intended for sale unless such package is marked as required by the next preceding section.

6. No person shall sell, or offer, expose, or have in his possession for sale any fruit packed in a closed package, upon which package is marked any designation which represents such fruit as of finest, best or extra good quality, unless such fruit consist ol well-grown specimens of one variety, sound, of nearly uniform size, of good color for the variety, of normal shape and not less than ninety per cent free from scab, worm-holes, bruises and other defects, and properly packed.

7. No person shall sell, or offer, expose, or have in his possession for sale any fruit packed in any package in which the faced or shown surface gives a false representation of the contents of such package; and it shall be considered a false representation when more than fifteen per cent of such fruit is substantially smaller in size than, or inferior in grade to, or different in variety from, the faced or shown surface of such package.

8. Every person who, by himself or through the agency of another person, violates any of the provisions of this Act shall, for each offense, upon summary conviction, be liable to a fine not exceeding one dollar and not less than twenty-five cents for each package which is packed, sold, offered, exposed, or had in possession for sale contrary to the provisions of this Act, together with the costs of prosecution: and in default of payment of such fine and costs, shall be liable to imprisonment, with or without hard labor, for a term not exceeding one month, unless such fine and the costs of enforcing it are sooner paid.

9. Whenever any fruit packed in a closed package is found to be falsely marked, any inspector charged with the enforcement of this Act may efface such false marks and mark 
the words "falsely marked" in a plain and indelible manner on such packaige.

The Inspector shall give notice by letter or telegram to the packer whose name is marked on the package before he marks the words "falsely marked" on such package.

10. Every person who wilfully alters, effaces, or obliterates wholly or partially, or causes to be altered, effaced or obliterated, any inspector's marks on any package which has undergone inspection shall incur a penalty of forty dollars.

II. The person on whose behalf any fruit is packed, sold, offered or had in possession for sale. contrary to the provisions of the foregoing sections of this Act, shall be prima facie liable for the violation of this Act.

12. Any person charged with the enforcement of this Act may enter upon any premises to make any examination of any packages of fruit suspected of being falsely marked in violation of any of the provisions of this Act, whether such packages are on the premises of the owner, or on other premises, or in the possession of a railway or steamship company; and any person who obstructs or refuses to permit the making of any such examination shall, upon summary conviction, be liable to a penalty not exceeding five hundred dollars and not less than twenty-five dollars, together with the costs of prosecution, and in default of payment of such penalty and costs, shall be liable to imprisonment, with or without hard labor, for a term not exceeding six munths. unless the said penalty and costs of enforcing it are sooner paid.

13. In any complaint, information or conviction under this Act, the matter complained of may be declared, and shall be held to have arisen, within the meaning of Part LVIII of The Criminal Code, 1592 at the place where the fruit was packed, sold, offered, exposed or had in possession for sale.

I4. No appeal shall lie from any conviction under this Act except to a superior, county, circuit or district court, or the court of the sessions of the peace having jurisdiction where the conviction was had: and such appeal shall be brought, notice of appeal in writing given, recognizance entered into, or deposit made within ten days after the date 
of conviction; and such trial shall be heard, tried, adjudicated upon and decided, without the intervention of a jury, at such time and place as the court or judge hearing the trial appoints, within thirty days from the date of conviction, unless the said court or judge extends the time for hearing and decision beyond such thirty days; and in all other respects not provided for in this Act the procedure under part LVIII of The Criminal Code, I\$92, shall, so far as applicable, apply.

15. Any pecuniary penalty imposed under this Act shall, when recovered, be payable one-half to the informant or complainant and the other half to His Majesty.

I6. The Governor in Council may make such regulations as he considers necessary in order to secure the efficient enforcement and operation of this Act: and may by such regulations impose penalties not exceeding fifty dollars on any person offending against them; and the regulations so made shall be in force from the date of their publication in The Canada Gazette or from such other date as is specified in the proclamation in that behalf; and the violation of any such regulation shall be deemed an offense against this Act and punishable as such.

\section{APPLE SHIPPERS' RULES}

The following important resolutions concerning the apple trade are taken from the reports of the National Apple Shippers' Association. (See Year Book Nat. Ap. Ship. Asso., I $900: 5$.)

Standard barrels. - Resolved. That this Association recognizes as the standard barrel for apples, a barrel which is of the capacity of a flour barrel, which is $17^{1} 8$ inches in diameter of head, and $28 \frac{1}{2}$ inches in length of stave, and bulge not less than 64 inches, outside measurement. (Adopted Aug. I, I895. Amended Aug. 6, 1897.) 
Requirements for No. I apples.-Resolved, That the standard for size for No. I apples shall not be less than $2^{1} \frac{1}{2}$ inches in diameter and shall include such varieties as the Ben Davis, Willow Twig, Baldwin, Greening, and other varieties kindred in size. That the standard for such varieties as Romanite, Russett, Wine Sap, Jonathan, Missouri Pippin, and other varieties kindred in size shall not be less than $2^{1}{ }_{4}$ inches. And further that No. $r$ apples shall be at time of packing practically free from the action of worms, defacement of surface, or breaking of skin; shall be hand-picked from the tree, a bright and normal color, and shapely form.

Requirements for No. 2 apples. - No. 2 apples shall be handpicked from the tree; shall not be smaller than $2^{1} 4$ inches in diameter. The skin must not be broken or the apple bruised. This grade must be faced and packed with as much care as No. I fruit. (This rule determining what a No. 2 apple shall be was made a by-law of this Association Aug. 3, Igco, and appears among the by-laws.)

Barrel legislation.-Resolved, That the State Vice-Presidents be directed to prepare proper resolutions, urging the enactment by their respective State Legislatures of legislation making the legal barrel for apples conform to the package adopted by this Association-that is, $17^{1}{ }_{8}$ inches head and $281 / 2$ inches stave, with bulge not less than $6+$ inches, outside measurement. (Adopted Aug. 2, 1895. Amended Aug. 6, 1897.)

Transportation necessitics. - Resolved, That this Association strongly urge the necessity and fairness of the adoption of a uniform weight of 150 pounds for a barrel of apples as a basis of rate thereon and directs the new Transportation Committee of this body to immediately take steps to urge the acceptance of such weight on part of the rate-making committees of the railroads. (Adopted Aug. 6, I897.)

Resolved, That the Transportation Committee be directed to secure from the transportation companies a regular bill of lading instead of the "Shippers' Loading and Count" Bill of Lading. (Adopted Aug. 6, I897.) 
Resolved, That the Transportation Committee recommends that a vigorous protest be made against present methods regarding claims against transportation companies and the demand that a settlement must be made no later than from thirty to sixty days from the filing of a claim for loss or damage accompanied by proper proofs, and that sister organizations be requested to assist in the agitation for justice until justice shall be accorded just claimants. (Adopted Aug. 4 , I895.)

Protection during growth, - The leading agricultural papers of the country are doing a splendid work in directing the attention of fruit growers to the means offered for the detection, location, and correction of fungus and other diseases of apples. It is quite within the province of a deliberative body like ours, composed as it is of representative dealers and exporters from different sections of the country, to express its appreciation of the value of the scientific deductions, the practical application of which is doing so much annually toward saving crops in infected districts from utter annihilation.

This Association would fail in its duty if it refused to recognize a widespread neglect of the advantages afforded by judicious cultivation and spraying of apple orchards, as recommended by state, county, and district agricultural societies. Fruit growers, especially in the east, must adopt these measures if they expect to retain their hold upon the trade of the country and continue their present position in the apple markets of Europe.

In view of these facts and conditions be it therefore

Resolved, that the members of this Association desire it to be placed upon record that they will, as far as possible, continue the agitation upon this now most important question of the proper care of fruit during cultivation, and to that end be it further resolved that copies of this recommendation be forwarded to the agricultural press of the country with a request for the endorsement and publication of such part as may seem to them fit and proper. 


\section{THE NATIONAL LEAGUE OF COMMISSION} MERCHANTS OF THE UNITED STATES

Shippers seeking reliable commission men to whom fruit may be consigned may find it convenient to. consult the following roster of members of the National League of Commission Merchants. The present offcers of the League are: D. W. Longfellow, Minneapolis, President; A. Warren Patch, Boston, Secretary, and C. W. Nokes, Cleveland, Treasurer.

The following statement of the objects of the league is made by its officers:

"Individuals or isolated communities can accomplish but limited results, therefore an organization of national extent and influence is indispensable.

"In this organization we propose to combine good, responsible commission merchants of every large commercial center, and with the aid of growers, producers, and shippers, either organized or unorganized, work together for the general welfare of the trade.

"A large percentage of the food products of the earth is . handled on commission. The commission merchant is, and of necessity must always be, an important factor in the commerce of the world.

"Our organization lays its foundation on the personal integrity and financial responsibility of its individual members.

"The conditions of membership are exacting, but not exclusive. Reputable commission merchants, where an organization may be legally formed, are invited to join us under our constitution and by-laws. An unworthy, irresponsible commission merchant may, by misrepresentation, enter this organization, but when his unfitness or the unworthiness of any member is discovered, expulsion will surely follow.

"Financial soundness and honesty for the individual members, combined in a national organization of broad com- 
mercial views. must and will command the confidence and respect of the American people.

"To promote these ends we invoke aid and sympathy of all commercial and agricultural organizations.

"The rapidity and facility of transportation make all markets accessible, all products obtainable; the products of a single farm, dairy or garden may be distributed over and consumed in more than half the states in the Union.

" Every grower, producer, or shipper may reach the $\mathrm{Na}$ tional League through his commission merchant, and have his views for the general welfare carefully considered.

' 'Farmers' clubs, fruit and vegetable growers' associations, shippers of butter and other dairy products, and all commercial organizations, will find us ready to unite with them in defeating unjust laws, in collecting and disseminating information. in improving business methods, in resisting discriminations and exactions, and in demanding and enforcing responsibility and integrity.

"We claim no section; we are non-partisan and non-sectarian. We guarantee our sympathy and support to every enterprise that may increase the rewards of labor or add to the comfort or happiness of the home.

"The following resolutions were adopted at the Second Annual Convention in Cincinnati, January Io, 1894 :

“.' Ist.-That the membership of this National League is composed of reputable commission merchants in each city where a Branch League has been established, and that they are all worthy of the confidence of any and all shippers; that while one of the objects for the establishment of this League is to further the interests of its members in an increase of business, yet another and very important object to the shipper is to place within his reach such houses as he will at all times feel safe in shipping to, and at the same time to protect him against the frauds who sail under the head of commission merchants, who, with their smooth tongues, flaming letter heads, and fabulous quotations, induce shipments, for which they never expect to make any returns, or by some other trickery cheat the shipper out of his just returns. 
“' 2d.-That it is the purpose and intention of this $\mathrm{Na}$ tional League to ferret out these fraudulent houses, to keep a record of them, and to furnish any necessary information regarding such houses to all shippers of produce who may inquire for the same.'

" For such information inquire of the Secretary of the Branch League in the city in which the party resides of whom you wish a report." "

\section{SECRETARIES OF BRANCH LEAGUES}

Baltimore-Edw. S. Evans, 214 Light Street, Baltimore, Md. Boston-H. H. Kendall, ${ }_{5}$ F. H. Market, Boston, Mass. Buffalo-M. U. Mackey, to W. Market Street. Buffalo. N. Y.

Chicago-Theo. C. H. Wegeforth, I33 S. Water Street, Chicago.

Cincinnati-H. C. Beekley, 244 W. Sixth Street, Cincinnati, $O$.

Cleveland-C. W. Nokes, 36 Huron Street, Cleveland, O.

Columbus-C. C. Vail, II E. Town Street, Columbus, O.

Denver-F. 11. Leonard, I52S-30 Market Street, Denver, Col.

Detroit-John D. Wiley, 20 Woodbridge Street, W. Detroit. Mich.

Indianapolis-B. F. Hitz, $30 \mathrm{~S}$. Delaware Street, Indianapolis.

Kansas City-Charles G. Haines, II2 W. Fourth Street, Kansas City, Mo.

Louisville-S. S. Thompson, 210 Jefferson Market, Louisville, $\mathrm{Ky}$.

Memphis-L. Lawhorn, $3+2$ Front Street, Memphis, Tenn.

Milwaukee-J. H. Wussow, 269 Broadway, Milwaukee, Wis. Minneapolis-D. W. Longfellow, 208 N. Sixth Street, Minneapolis, Minn.

Mobile-Philip Muscat, 64 S. Commerce Street, Mobile, Ala.

New Orleans-George W. Davidson, Poydras Street, New Orleans, La.

New York-E. A. Brown, 306 Washington Street, New York.

Omaha-W. H. Hazzard, 508 S. Tenth Street, Omaha, Neb.

Philadelphia-S. S. Darmon, I20 Spruce Street, Philadelphia, $\mathrm{Pa}$. 
I92 FRUI'T IARVESTING, S'TORING, MARKE'TING

Pittsburg-Charles A. Muehlbronner, 623 Liberty Street, Pittsburg, Pa.

Richmond-R. M. McIntire, 1320 E. Cary Street, Richmond, Va.

St. Louis-G. G. Fairham, 9I 8 N. Third Street, St. Louis, Mo. St. Paul-J. E. Mulrooney, 79 E. Third Street, St. Paul, Minn.

\section{ROSTER OF MEMBERS}

BALTIMORE, MD.

C. H. Anderson \& Co., 123 S. Calvert Street.

Fruits and General Produce.

Blankfard \& Meginniss, 135 W. Pratt Street.

Fruits and General Produce.

Thomas Bond \& Son, 216 Light Street,

Fruits and Vegetables.

I. Cooke \& Sons, 7 W. Pratt Street,

Butter, Eggs, Poultry, and Dried Fruits.

Dix \& Wilkins, 9 E. Lombard Street,

Florida, California, and Foreign Products.

T. H. Evans \& Co., 214 Light Street Wharf,

Fruits and General Produce.

Henderson, Linthicum \& Co., 3 E. Camden Street.

Fruits and General Produce.

T. H. Kepner \& Co., It E. Camden Street,

Fruits and General Produce.

G. M. Lamb \& Bro., 30I Exchange Place,

Butter, Eggs, and Poultry.

Edward L. Palmer \& Co., 1 I E. Lombard Street,

Fruits, Canned Goods, Groceries.

C. Shipley \& Co., 107 S. Calvert Street,

Fruits and General Produce.

William A. Schutze \& Co., 118-120 S. Charles Street.

Butter, Eggs, Poultry, Dried Fruits.

John Staum \& Sons, 21o Light Street,

Fruits and Vegetables.

Stevens Bros., 226 Charles Street,

Fruits and Produce.

The Snyder \& Blankfard Co., 226 Light Street,

Vegetables and Fruits.

C. P. Tatem \& Co., I2I Light Street,

Fruits and General Produce. 


\section{BOSTON, MASS.}

Bennett, Rand \& Co., I9 and 20 N. Market Street,

Fruits and Produce.

W. H. Blodget Co., 50 Clinton Street,

Fruits and Produce.

F. H. Bowles \& Co., II3-II5 S. Market Street,

Butter, Cheese, and Eggs.

Chapin Brothers, 97 S. Market Street.

Fruit, Produce, and Southern Produce.

Conant \& Bean, I5 N. Side Faneuil Hall Market,

Fruits and General Produce.

Curtis \& Co., 104-106 Faneuil Hall Market,

Fruits and General Produce.

T. E. Holway \& Co., I5 N. Market Street,

Fruits and General Produce.

Amos Keyes \& Co., 22 Blackstone Street,

Butter, Cheese, Eggs, Poultry, Game.

A. \& O. W. Mead \& Co., 35 N. Market Street,

Fruits, Produce, Butter, Eggs, Poultry.

J. D. Mead \& Co., cor. Clinton and Fulton Streets,

Fruits and General Produce.

Patch \& Roberts, 17 N. Market Street.

Fruits and General Produce.

Porter Brothers Company, 99-1or S. Market Street,

California Fruits and Vegetables.

Snow \& Co., +8 Clinton Street,

Fruits and Vegetables.

Winn, Ricker \& Co., 93 Faneuil Hall Market,

Foreign and Domestic Fruits and Produce.

York \& Whitney, I N. Market Street,

Fruits and Vegetables.

\section{BUFFALO, N. Y.}

Bean, Coward \& Chaddock, Elk Street Market,

Fruits and Produce.

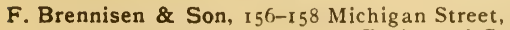

Fruits and General Produce.

J. H. Gail, 94 W. Market and I53 Michigan Streets.

Fruits and General Produce.

George Hornung, 5t W. Market and II 5 Michigan Streets,

Fruits and Produce. 
194 FRIIT HARVESTING, STORING, MARKFTING;

Mackey \& Williams, 62 W. Market and 125 Michigan Streets, Fruits and Produce.

Paine \& Williams, $82-84$ W. Market Street,

Fruits and General Produce.

Potter \& Williams, I $4+$ and $I+S$ Michigan Street,

Fruits and General Produce.

Rogers Commission House, 149 Michigan Street,

Fruits and General Produce.

Isaac G. Vishion, 66 W. Market Street,

Butter, Eggs, and General Produce.

J. J. White, 68 W. Market and 179-18I Perry Streets,

Fruits and General Produce.

\section{CHICAGO, ILL.}

M. Baker \& Co., 93 S. Water Street,

Fruits and General Produce.

A. H. Barber, 229 S. Water Street,

Butter, Eggs, Poultry, and Produce.

Barnett Bros., 159 S. Water Street,

Fruits and General Produce.

R. A. Burnett \& Co., 163 S. Water Street,

Honey, Fruit, and Produce.

Cuneo Brothers, II3 S. Water Street,

Foreign and Domestic Fruits, Nuts, etc.

Frost Bros., I22 S. Water Street,

Fruits and Genera! Produce.

Garibaldi \& Cuneo, SI-83 $_{3}$ S. Water Street,

Foreign and Domestic Fruits, Nuts, etc.

M. George \& Co., 95 S. Water Street,

Fruits and General Produce.

Moses Gray \& Co., 249-51 S. Water Street,

Butter, Eggs, Poultry, Fruits, Produce.

F. Heinze \& Co., 171 S. Water Street,

Fruits and Vegetables.

Lepman \& Heggie, IoS-IIo S. Water Street, Butter, Eggs, Poultry, Game.

C. F. Love \& Co., 89 S. Water Street.

Fruits and General Produce.

George Middendorf \& Co., 135-I37 S. Water Street.

Fruits, Produce, Butter, Eggs, Cheese.

A. L. McClay \& Co., I+I S. Water Street,

Fruits and Vegetables. 
F. E. Nellis \& Co., $153^{-155}$ S. Water Street,

Fruits and General Produce.

F. Newhall \& Sons, I3I S. Water Street,

Fruits, Apples, Cranberries, etc.

Mark Owen \& Co., I $x_{5}$ S. Water Street,

General Commission Merchants.

Porter Bros. Co., 97 S. Water Street,

California, Domestic, and Foreign Fruits.

J. C. \& C. R. Scales, II 4 S. Water Street,

P. C. Sears, I2I S. Water Street,

Fruits and Produce.

Fruits and General Produce.

Smith-Cordes Co., I39 S. Water Street,

Vegetables, Fruits, Produce.

H. P. Stanley Co., 75 S. Water Street,

Apples, Cranberries, Oranges, Lemons.

G. M. H. Wagner \& Sons, 165 S. Water Street,

Fruits and Vegetables.

Wayne \& Low, is 5 S. Water Street,

C. H. Weaver \& Co., I2y S. Water Street,

Fruits and Produce.

Vegetables, Fruits, Produce.

Theo. C. H. Wegeforth \& Co., I33 S. Water Street,

Fruits and General Produce.

J. H. White \& Co., I04-106 S. Water Street,

Eggs, Butter, Poultry, Veal, Game.

\section{CINCINNATI, O.}

F. Ankenbauer \& Sons, IIS-IIS $1 / 2$ E. Front Street;

Fruits and Produce.

Armacost, Riley \& Co., I I E. Front Street,

Fruits and General Produce.

H. C. Beekley \& Co., $2+4$ W. Sixth Street,

Fruits and Produce.

I. J. Cannon \& Co., IIo E. Front Street,

John Curren \& Co., 29 Walnut Street,

Fruits and Vegetables.

C. M. Davidson \& Co., I12 E. Front Street,

Fruits and Produce.

Foreign and Domestic Fruits.

F. Delsignore \& Co., II+-II6 E. Front Street,

Foreign and California Fruits. 
I96 FRUIT HARVESTING, STORING, MARKETING:

F. Devoto \& Bro., IoS E. Front Street,

Foreign and Domestic Fruits, Berries.

M. Fugazzi \& Co., 132-13+ W. Sixth Street,

Fruits and Vegetables.

Funck Brothers, 22S-230 W. Sixth Street,

Southern Fruits and Vegetables.

Glas, Bloom \& Co., II5-II7 E. Front Street,

Green and Dried Fruits, Produce.

J. B. Hammer \& Co., 125 E. Front Street,

Fruits and General Produce.

D. Hoppe \& Co., 3I Walnut Street,

Eggs, Butter, Poultry, Game, Fruits.

J. Leverone \& Co., $\mathrm{IOO}^{\mathrm{rO} 2}$ E. Front Street,

Fruits and Vegetables.

G. E. Markley \& Co., 2I2-2I+ W. Sixth Street,

Foreign and Domestic Fruits, Vegetables.

F. J. Nobel, 208 W. Sixth Street,

Fruits, Vegetables, Hot-house Products.

Pieper \& Berghegger, $138 \mathrm{~W}$. Court Street,

Fruits, Vegetables, Butter, Eggs.

Henry Ransick \& Sons, 226 W. Sixth Street,

Fruits and Produce.

P. J. Reitz \& Co., I2I E. Front Street,

Fruits and Vegetables.

Smith, Reiley \& Co., 204 W. Sixth Street,

Fruits and Vegetables.

Telker \& Dunker, IIS E. Court Street,

Fruits, Produce, Butter, Eggs, Poultry.

Weil, Brockman \& Co., rog E. Front Street,

Fruits and Vegetables.

S. \& M. Weil \& Co., Io6 E. Front Street,

Fruits, Vegetables, Berries, Melons.

\section{CLEVELAND, 0.}

W. A. Banks Co., $84-86$ Broadway,

Corso Brothers, 115 Broadway,

Fruits and Produce.

Wholesale Fruits.

A. R. Duncan, Jr., II9-I2I Sheriff Street,

Butter, Cheese, Eggs, Poultry, Produce.

Haas Brothers, 76-78 Broadway,

Fruits and General Produce. 
Hayes, Blair \& Co., I 20 Broadway,

Tropical and Domestic Fruits, Produce.

Hurd \& Ricksecker, 9 Huron Street,

The Kelley Co., r50-152 Sheriff Street,

Fruits and Produce.

Fruit, Produce, and Seeds.

D. Martin \& Co., 84-86 Broadway,

Fruits and Produce.

Myers, Weil \& Deutch, IO-I2 Huron Street,

General Fruit and Produce Commission Merchants.

The C. U. Nokes Co., 36-38 Huron Street,

Fruits and General Produce.

Strauss \& Joseph, 9I Broadway,

Wholesale Produce Commission.

George Willard, 27o Pearl Street,

Wholesale Commission Merchant.

COLUMBUS, 0.

Henry Becker, I2 I S. Fourth Street,

Fruits, Vegetables, Butter, Eggs.

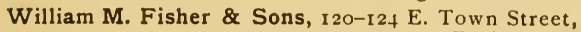

Fruits and Produce.

Evans \& Turner, Town Street, cor. Fourth,

Fruits and Produce.

Pletsch \& Sutton, Town Street, cor. Fourth,

William Larimore, I29 S. Fourth Street,

Fruits and Vegetables.

Fruits and Produce.

Sutton Brothers, I I3-II5 S. Fourth Street.

Fruits and Produce.

Henry Turkopp \& Co., Town and Third Steets,

J. P. Vail \& Sons, IIt E. Town Street,

Foreign and Domestic Fruits.

Fruits and Produce, Butter and Eggs.

DENVER, COL.

The Donaldson \& Howard Com. Co., 1548-1550 Market Street,

Fruits and Produce.

Humphreys Commission Co., 1520-1522 Market Street,

Fruits and Produce. 
F. H. Leonard \& Co., 1528-1530 Market Street, Butter, Cheese, and Eggs.

The Liebhardt Commission Co., I624-1630 Market Street, Fruits and Produce. Pinkett Brothers, 1645 Market Street,

Butter, Eggs, and Poultry.

\section{DETROIT, MICH.}

Lichtenberg \& Sons, 19-25 W. Woodbridge Street,

Fruits, Produce, Beans, etc.

Walker Egg and Produce Co., 54-56 Woodbridge Street, Fruits and Produce.

Edward Read, 26 W. Woodbridge Street,

Fruits, Vegetables, Beans, etc.

H. F. Rose \& Co., 24 W. Woodbridge Street,

Fruits and Produce.

Charles W. Rudd, 3I W. Woodbridge Street,

Fruits and Produce.

Alfred Rush \& Sons, 45-49 Woodward Avenue,

Fruits and Produce.

D. O. Wiley \& Co., 2o Woodbridge Street,

Fruits, Produce, Beans, etc.

\section{INDIANAPOLIS, IND.}

J. H. Crall \& Co., I22 S. Delaware Street,

Fruits and Vegetables.

George Hitz \& Co., 30-32 and 68-70 S. Delaware Street, Fruits and Produce.

James L. Keach, II S. Delaware Street,

Fruits and Produce.

John W. Neumann \& Co., II8-I20 S. Delaware Street,

Fruits and Produce.

E. F. Shideler \& Co., $43-45$ S. Delaware Street,

Fruits and General Produce.

Syerup \& Co., 22-24 S. Delaware Street,

Foreign and Domestic Fruits, Vegetables.

George B. Walton \& Co., 36 S. Delaware Street,

Fruits and General Produce.

The D. A. Williams Produce and Commission Co., 13 $\mathrm{I}$ E. Maryland Street. 


\section{KANSAS CITY, MO.}

A. W. Bear Commission Co., I19 E. Fourth Street, Butter, Eggs, and Poultry.

T. C. Bottom \& Co., 540 Walnut Street,

Fruit and Vegetables.

C. C. Clemons \& Co., 204 Temple Block,

Wholesale Fruits and Produce.

O. C. Evans \& Co., 302 Delaware Street,

Apples, Potatoes, Onions, and Cabbage.

C. M. Feiring \& Co., 409 Walnut Street,

Butter, Eggs, Poultry, and Cheese. Ginocchio-Jones Fruit Co., 5I9-כ2I Walnut Street,

Foreign and Domestic Fruits.

A. S. Haines \& Son, II2 W. Fourth Street,

Fruits, Vegetables, and Produce.

H. Kesting, 4II Walnut Street,

Foreign and Domestic Fruits and Nuts.

Papendick Produce Co., 3 Io Grand Avenue,

Eggs, Butter, and Poultry.

P. V. Rocco, Bro. \& Co., 5I5-5I7 Walnut Street,

Fruits, Nuts, etc.

D. E. Smeltzer \& Co., 520 Walnut Street,

Small Fruits, Celery, and Vegetables.

\section{LOUISVILLE, KY.}

John T. Allen \& Co., I08-110 W. Jefferson Street,

Fruits and Vegetables.

E. H. Bowen \& Co., II9-I23 Washington Street,

Apples, Potatoes, Onions, Beans. Jos. Denunzio Fruit Co., 316 and 322 W. Jefferson Street,

Fruits and Nuts.

A. M. Emler, 24I Jefferson Market,

Potatoes, Onions, Apples, and Cabbage.

Charles H. Kahlert, 619 W. Market Street,

Fruits, Produce, and Vegetables.

Kohlhepp \& Iula, 204 E. Jefferson Street,

Fruits and General Produce.

Mayer, Mitchell \& Co., 215 E. Jefferson Street,

Fruits, Vegetables, etc.

John Schaefer \& Sons, 33I E. Market Street,

Potatoes, Onions, Apples, Cabbage, etc. 
Schwarz Brothers, 94I to 945 E. Market Street,

Potatoes, Onions and Onion Sets.

D. B. Sperry, 214-2I6 Second Street,

Apples, Potatoes, Beans, Onions, etc. Thompson \& Co., 210-212 Jefferson Market,

Fruits, Vegetables, Melons, etc.

\section{MEMPHIS, TENN.}

D. Canale \& Co., 329 Main Street,

M. E. Carter \& Co., Memphis, Tenn.,

Fruits and Produce.

T. C. Guinee \& Co., Front Street,

L. Lawhorn \& Co., 342 Front Street,

Fruits and Produce.

Fruits and Produce.

Fruits, Produce, and Potatoes.

Seessel \& Ashner, 336 Front Street,

Fruits and Produce.

\section{MIL WAUKEE, WIS.}

E. R. Godfrey \& Sons Co., 257-259 Broadway,

Nichols, Janssen \& Klein, 277 Broadway,

Fruits and Produce.

Pastorino \& Schiappacasse, 287 Broadway,

Fruits and Vegetables.

A. J. W. Pierce Co., 305 Broadway,

Fruits and Nuts.

Fruits and Vegetables.

J. Seefeld \& Son, $283-285$ Broadway,

Foreign and Domestic Fruits.

R. Stafford Co., 265 Broadway,

Fruits, Produce, and Grocers' Specialties.

Charles A. Schmidt \& Co., 26I-263 Broadway,

J. H. Wussow \& Co., 269 Broadway,

Fruits and Produce.

Fruits and Produce.

\section{MINNEAPOLIS, MINN.}

G. L. Bradley \& Co., 2I and 22 Central Market,

Butter, Eggs, Cheese, and Beans.

Connery Fruit Company, 6or to 609 Second Avenue, N.,

Fruits, Nuts, Figs, Dates.

Gamble-Robinson Commission Company, 224-226 Sixth Street, N., 
Grinnell, Collins \& Co., 212-2I 4 Sixth Street, N.,

Hillman Bros., 204-206 Sixth Street, N.,

Fruits and Produce.

Fruits, Vegetables, Dairy Products.

Longfellow Bros. \& Co., 208 Sixth Street, N.,

Fruits, Foreign and Domestic.

Porter Brothers Co., 228-230 Sixth Street, N.,

Foreign and Domestic Fruits.

E. P. Stacy \& Sons, 200-202 Sixth Street, N.,

Foreign and Domestic Fruits.

\section{MOBILE, ALA.}

Mertz, Ibach \& Co., 4 N. Commerce Street,

Fruit, Grain, Flour, Produce.

Muscat \& Lott, 64 S. Commerce Street,

Fruit, Produce, Poultry, Eggs.

Roh \& Partridge, 58 N. Commerce Street,

Fruit and Produce.

\section{NEW ORLEANS, LA.}

Bernard Antony \& Co., 45 I S. Peters Street,

Fruits and Produce.

Joseph A. Ball, 403-405 S. Peters Street,

Fruits and Produce.

Barbot \& Stork, 217 Poydras, cor. Fulton Street,

Fruits and Produce.

Louis Darring, 319 Poydras Street,

Fruits, Produce, and Vegetables.

George W. Davidson \& Co., 45-47 Poydras Street,

Fruits and Produce.

Stephen D'Amico, Poydras cor. Fulton Street,

Foreign and Domestic Fruit.

H. J. Laux \& Co., 211 Poydras Street,

Brokers and Commission Merchants.

Philip Nagele, 49 Poydras Street,

Fruits and Produce.

Noble \& Saulter, 407-409 S. Peters Street,

S. Oteri, ${ }_{403}$ S. Front Street,

Fruits and Produce.

Wholesale Fruit and Produce. Jos. Rittiner \& Co., 321-323 Poydras Street.

Fruits and Produce. 
Charles Roth, 20I Poydras Street,

Seessel, Ashner \& Sugarman, 529-533 Poydras Street, Fruits and Produce.

Segari \& Meyer, 405 S. Peters Street,

A. Spano \& Co., 207 Poydras Street,

Fruits and Produce. Fruits and Vegetables.

\section{NEW YORK}

J. H. Bahrenburg, Bro. \& Co., ro5 Murray Street, Fruits and Produce.

Bennett \& Hall, I6I West Street,

E. A. Brown, 306 Washington Street,

Fruits and Produce.

Fruits, Vegetables, Poultry. Game, Eggs.

R. W. Dixon \& Son, 266 Washington Street,

Fruits, Produce, Poultry, Game.

S. B. Downes \& Co., 203 Duane Street.

Fruits and Produce. Dressed Poultry. Henry Elwell \& Co., 310 Washington Street,

Berries, Peaches, Produce.

Charles Forster, 44 Harrison Street,

Fruits and Vegetables.

S. H. \& E. H. Frost, 319 Washington, cor. Jay Street, Fruits and Vegetables.

G. Furman \& Co., West Washington Market,

Fruits and Produce.

Furman \& Page, I12 Warren Street,

Fruits, Vegetables, and Produce. William Gamble \& Co., Is5 Reade Street,

Fruits and Vegetables, Butter, Eggs.

J. H. Killough \& Co., 157 and 158 West Street,

Fruits and Produce.

Austin Kimball \& Co., 78 Park Place,

Fruits and Vegetables.

E. P. Loomis \& Co., 95 Barclay Street,

Fruits and Produce. McCormick, Hubbs \& Co., 297 Washington Street, Foreign and Domestic Fruits. John Nix \& Co., 28I Washington Street, 
Phillips \& Sons, yos Murray, near Washington Street,

Fruits, Produce, Poultry. Calves.

P. Ruhlman \& Co., 26r Washington Street,

Foreign and Domestic Green Fruits.

Schott \& Franke, 280 Washington Street,

Fruits and Vegetables.

A. F. Young \& Co., Duane, cor. Washington Street,

Vegetables and Fruits.

\section{OMAHA, NEB.}

O. W. Butts, SoI tó 8 I I Jones Street,

California, Florida, and Tropical Fruits.

G. W. Icken \& Co., I207 Howard Street,

Fruits, Game and Produce.

Perry, Bauer \& Ennis, I213 Howard Street,

Butter, Eggs, Poultry, and Game.

W. E. Riddell, $4 \mathrm{r}_{3}$ S. Eleventh Street.

Butter, Eggs, and Poultry.

H. G. Streight \& Co., I017 Howard Street,

Fruits and V'egetables.

\section{PHILADELPHIA, PA.}

Barker \& Co., 32I-323 N. Front Street,

Fruits and Produce.

Brown \& McMahon, 334 N. Front Street,

Fruits and Vegetables.

G. W. Butterworth, N. E. cor. Second and Dock Streets,

S. S. Darmon, r2o Spruce Street,

Fruits and Vegetables.

Fruits, Produce, and Vegetables.

J. D. Hendrickson, 302 N. Front Street,

Apples, Potatoes, and Other Produce.

C. G. Justice, 123 Dock Street,

W. H. Michael \& Son, II 4 Dock Street,

Fruits and Vegetables.

Fruits and Vegetables.

Roberts \& Andrews, I29-131 Callowhill Street,

Fruits and V'egetables.

Edward Roberts, 226-228 N. Delaware Avenue,

R. A. Shetzline \& Sons, I Vine Street,

Fruits and Vegetables.

Fruits and Vegetables.

William Smith \& Co., 336 N. Front Street,

Fruits, Vegetables, and Poultry. 
204 FRUIT HARIESTING, STORING, MAKKETING;

J. W. Thorn \& Co., 325 N. Water Street,

Apples, Potatoes, and Onions. William Weinert \& Co., S. W. cor. Front and Vine Streets, J. P. Wilson, II6 Dock Street,

Fruits and Produce.

Fruits. Vegetables, Poultry, Eggs.

E. S. Woodward, 22 Dock Street,

Fruits and Vegetables.

\section{PIT TSBURGH, PA.}

Ash \& Baldwin, 937-939 Liberty Avenue,

Crutchfield \& Woolfolk, 613 Liberty Street,

General Produce.

Dale \& Cannon, 640 Grant Street,

Fruits and Produce.

Dennis Hayes, $6+6$ Grant Street,

Fruits and Vegetables.

Vegetables, Berries, etc. Iron City Produce Co., 623 Liberty Street.

Foreign and Domestic Fruits.

H. J. McCracken \& Co., 6ł Grant Street,

W. E. Osborne Co., 635 Liberty Street,

General Produce.

Seward \& Kurts, 640 Grant Street,

Fruits and Produce.

Foreign and Domestic Fruits.

Albert M. Travis, 645 Liberty Avenue,

Fruit and Produce Commission Merchant. John Wallace, 63I Liberty Street,

Fruits and Vegetables, Eggs, PouItry.

\section{RICHMOND, VA.}

William Jenkins \& Sons, I3II E. Cary Street,

Fruits and Vegetables.

J. D. McIntire \& Co., I320 Cary Street,

Fruits and Vegetables.

F. S. Padgett \& Co., I303 E. Cary Street, Butter, Eggs, and Poultry. John T. Powers, E. Cary Street,

Fruits and Vegetables.

W. F. Seymour, 1317 E. Cary Street,

Butter, Fruit, and Vegetables. 
ST. LOUIS, MO.

F. W. Brockman Commission Co., $805-809$ N. Third Street, Eggs, Poultry, Butter.

George G. Fairham \& Bro., 9r8-920 N. Third Street, Fruits and Produce.

Gerber Fruit Co., 910-912 N. Third Street,

Fruits and Produce.

Gunn Fruit Co., 938-940 N. Third Street,

Foreign and Domestic Fruits.

Haueisen Bros., IOr7-IOI9 N. Third Street,

Fruits and Produce.

P. M. Kiely \& Co., 9I 4 N. Third Street,

Fruits and Vegetables.

Conrad Schopp \& Co., Northwest cor. Franklin Ave.,

Fruits and Vegetables.

George P. Schopp \& Co., 72I-723 N. Third Street,

Fruits, Produce, and Vegetables. Shaw \& Richmond, 829-831 W. Third Street,

Fruits and Produce.

Trescher \& Miller, 922 N. Third Street,

Game, Poultry, Eggs, Fruits, and Vegetables.

\section{ST. PAUL, MINN.}

R. E. Cobb, 3I-33 E. Third Street,

Fruits and Produce.

Dore \& Redpath, 70-72 E. Third Street,

Foreign and Domestic Fruits, Produce. R. A. Durkee, I32 E. Third Street,

C. C. Emerson \& Co., 26 E. Third Street.

Fruits and Produce.

Fruits and Produce.

J. W. Fillebrown, Ir 4 E. Third Street,

Fruits and Vegetables.

John B. Hoxsie, 103 E. Third Street.

Fruits and Produce.

J. E. Mulrooney \& Co., 79 E. Third Street,

Foreign and Domestic Fruits.

Minnesota Butter \& Cheese Co., 6I-63 E. Third Street, Butter and Cheese.

B. Presley \& Co., E. Third Street,

Foreign and Domestic Fruits. 


\section{COMMISSION CHARGES}

The regular rate of commission for making retail sales of fruit, even when these fruits arrive in carload lots, is ten per cent. Large shippers, however, by making special agreement with commission houses, often get better rates.

In the subjoined table, taken from the American Agriculturist Year Book, I898, p. 482 , the commission charges are givell as actually made at various points, but they apply as a rule to relatively small lots.

ACTLAL, COMMISSIONS CHARGED FOR HANDLING

\begin{tabular}{|c|c|c|c|c|c|c|c|c|}
\hline & $\frac{2}{2}$ & 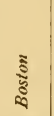 & 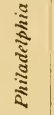 & 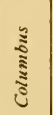 & 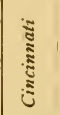 & 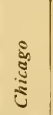 & 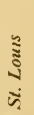 & 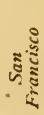 \\
\hline 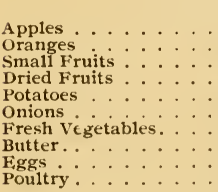 & $\begin{array}{c}\% \\
10 \\
10 \\
10 \\
5 @ 10 \\
10 \\
10 \\
5 @ 10 \\
5 \\
5 \\
5\end{array}$ & $\begin{array}{c}\% \\
8 \\
10 \\
10 \\
5 @ 10 \\
5 @ 8 \\
8 \\
5 @ 8 \\
5 \\
5 \\
5\end{array}$ & $\begin{array}{c}\% \\
5 @ 10 \\
10 \\
10 \\
5 \\
7 @ 10 \\
7 @ 10 \\
10 \\
5 \\
5 \\
5\end{array}$ & $\begin{array}{l}\% \\
8 @ 10 \\
8 @ 10 \\
7 @ 10 \\
5 @ 10 \\
10 \\
10 \\
10 \\
10 \\
10 \\
10\end{array}$ & \begin{tabular}{|c|}
$\%$ \\
$10 @ 15$ \\
10 \\
10 \\
10 \\
$5 c$. bu. \\
$10 @ 15$ \\
10 \\
5 \\
5 \\
5
\end{tabular} & $\begin{array}{c}\% \\
10 \\
10 \\
10 \\
5 \\
5 @ 10 \\
10 \\
10 \\
5 \\
5 \\
5\end{array}$ & $\begin{array}{r}\% \\
5 \\
10 \\
10 \\
5 \\
5 \\
5 \\
10 \\
5 \\
5 \\
5\end{array}$ & $\begin{array}{l}\% \\
8 \\
8 \\
8 \\
5 \\
5 \\
5 \\
8 \\
5 \\
5 \\
5\end{array}$ \\
\hline
\end{tabular}

VII. SHIPMENT IN REFRIGERATOR CARS

The following notes on the transportation of fruits in refrigerator cars are given in a recent number of Rural New Yorker ("W. W. H.," in Rural New Yorker, 60:259, April 6, I901):

"The use of cold storage in the transportation of fruits has increased greatly of late years, and we find a growing interest in this business from Canada to the south. Perishable 
products are thus put into distant markets, and the season during which they may be had by consumers is very much lengthened. Take strawberries. for example. Instead of having them in the New York market for three months, as would be the limit if we had to depend on what could be sent here without ice, they are on hand for eight months, although part of the time too expensive to be used by people of moderate means. Still, there are many who are willing to pay thirty to sixty cents per quart for strawberries in January. A few years ago the quantity received during the winter season was very limited, and these sometimes sold as high as $\$ 5$ per quart.

"As soon as the growers found that the fruit, of which they could sell but a small quantity at home, could be sent to distant points so as to arrive in good condition and bring a price that would give fair pay for their time and labor, those who had been raising only garden patches branched out into acres, and from Florida and the Carolinas the output increases from now and then a scattered carload to dozens and scores. This put new life into sections of the south that had been practically dead, so far as outside trade was concerned; labor was in demand, farm property increased in value, and in many places these conditions still hold good. Of course, as always happens, there were some who went into this business too deeply on the start, and suffered severe loss.

"The earliest strawberries come from Florida and California the latter part of December. At that season the quantity shipped is so small that no grower has a carload at any one time, so he uses the refrigerator chest. This is a heavy box made in various sizes from forty-eight to one hundred or more quarts. The first of these cases made were crude affairs. The berries got badly shaken in handling, and the water from the melting ice soaked them, so that they were in bad shape when opened. Improvements have been made to such an extent now that the berries are not damaged at all, opening up in as fine condition as when facked. As cold naturally goes down instead of up, the ice is put in a tight galvanized iron tray in the top of the chest, and the cover shuts down closely 
upon this. As the ice melts the water drains from a hole in the pan into an iron pipe, through which it runs out of the bottom of the chest. As soon as there is enough fruit forcarload lots, refrigerator cars are used. In these the whole interior of the car is cooled, and the ice does not come in contact with the produce shipped. These have been long used for beef and other perishable foods."

Cost of transportation.-In the same article some interesting figures are given showing the cost of shipping in the refrigerator cars. The statements are reliable, and I will quote them herewith. The writer says:

"There is no doubt that the railroads get their full share of the profits out of all the stuff they carry to market for the farmer. The following facts in regard to expenses were obtained from a southern shipper. The charge made by the railroad companies for hauling refrigerator cars from South Carolina points to New York and Philadelphia is $\$ 1.25$ per bushel crate, the minimum carload being one hundred crates. The express company furnishes the car, ice, etc., and looks after the re-icing in transit at 25 cents per crate. This is in addition to the charge made by the railroad company. Figuring on the minimum rate of one hundred bushel crates, the transportation charge between the points named would be $\$ 25$ for rent of car, ice, and re-icing on the way, and $\$ 125$ to the railroad company for hauling, making $\$ 150$ per car, or a trifle over $4^{1 / 2}$ cents per quart. Of course this can be reduced by putting more crates in the car, but there is a danger in overloading, and it is considered that the berries arrive at their destination in far better shape where they are not crowded to the top of the car, and a little space is left between the crates. Refrigerator chests are made in various sizes. Those holding forty-eight quarts will weigh, iced, two hundred pounds; eighty quarts, three hundred pounds; one hundred quarts, three hundred and fifty pounds; and one hundred and forty quarts, five hundred pounds, and the transportation charge is 76 cents per one 
hundred pounds from South Carolina points to New York and Philadelphia. The shipper furnishes his own ice and must provide for icing on the way, the railroad assuming no responsibility for the giving out of the ice, provided their train is nearly on time. Taking all things into consideration: the shipment in the iced chests is the most expensive, and it is said that but few use them who have sufficient quantities of fruit to use the iced cars. However, these refrigerator boxes are of great value to small shippers. and they are coming into use more and more, not only for shipment from the south but from northern points. We have recently had letters from people in Canada who were making arrangements to use these chests in shipments to markets in the United States. One wished to know whether it would do to paint or oil the inside of the chest to make them impervious to moisture. We have not seen any on which this has been tried, and all the receivers with whom we have talked seem to think that it would not be a good plan, as anything so penetrating as oil would be likely to affect the berries, which are nearly equal to nilk for absorbing odors. Lining the chest with heavy clean paper is a good plan. Some claim that shipments of berries in refrigerator boxes have sold at higher prices than those sent at the same time to the same market in ordinary crates in iced cars, but we are not able to find any instances of this discrimination that can not be traced to the difference in quality of the berries. Probably the man who ships comparatively few and uses the box takes a little more care in grading than the one who sends a carload. This has been our observation in regard to the berries we have seen opened here."

\section{REFRIGERATOR CARS}

The following account of the use of refrigerator cars for shipping southern fruits is given by Prof. F. S. Earle (Ala. Exp. Sta. Bul. 79: 106. March, 1897):

"Refrigerator cars were first built for the meat trade. The meat was hung in cold storage houses, and was loaded into the cars at, or near, the freezing point. In a tight, well- 
built car such a cold load would warm up very slowly, and a small amount of ice served to carry it safely to its destination. When it was attempted to use these cars for fruit, the hot load, fresh from the fields, soon melted the limited ice supply, and the cars invariably arrived heated and in bad order. To use these cars successfully it was found necessary to build cooling houses at the shipping points, in which the fruit could be cooled off before loading, as in the case of the meat. This caused delay in getting the fruit on the market, and made much additional expense. It, however, demonstrated the success of refrigeration for the transportation of fruits; and soon cars were built especially for the fruit trade, with sufficient ice capacity to cool off a load of hot fruit in transit and to keep it cool. At the present time there are a number of refrigerator car lines, with specially built fruit cars, that are actively competing for the fruit and vegetable carrying trade, so that any point having sufficient business to offer can secure efficient car service, with competent men to look after the proper loading and icing of the cars. Each line, of course, claims to have the best cars, and for difficult service there would certainly be considerable choice between them, but with the numerous re-icing stations that are now available, any of them will give satisfactory service, if properly loaded and handled.

"The main points to consider in selecting a refrigerator car for transporting produce are, first, its ice capacity, and second, its insulation. The ice tanks should hold at least five tons of ice, and six tons is even better. The position of the tanks, whether overhead or at the ends, is a question of minor importance. The car should be tightly built, with double walls and roof, with the space between them filled in with some non-conducting material, or by numerous linings of building paper with dead air spaces between them. The doors should be built like the walls and be of the same thickness, and they should fit as nearly air-tight as possible. Of course the car should be sweet and clean.

"It is usual for the refrigerator companies to furnish their own men for loading the cars, for proper loading is a point of 
so much importance that they do not care to trust the reputation of their cars to inexperienced men. The important points to secure in loading are, first, that the packages be so spaced that the cold air has immediate access tu all sides of them, and, second, that they be so secured that the load can not shift by the bumping of the cars while in transit. Thesc points are usually secured by piling the crates, or other packages, one above another in ticrs or ranks, from three to $s 1 x$ inches apart, and with lath or strips between each layer. Strips are placed upright against the end of the car, and a row of packages is placed on the floor, with the ends set snugly against these strips and carefully spaced. Light half-inch strips, as long as the width of the car, are placed across the ends of the packages, and the front one is nailed down, with a light nail, to the head of each package to prevent side shifting. Another row of packages is placed on these strips, each one directly above one in the lower row. These are again stripped and nailed, and so on to the top. The next course is placed with the ends snugly against the ends of the first course, so that the air spaces are continuous. When the center of the car is reached, begin in the other end and load in the same way. A space will usually be left at the last, too narrow to admit another course of packages; and the car must now be braced to prevent the courses from shifting endwise. Pieces of $1 \times 6$ inch board are set up against the ends of each rank of packages, and other strips are nailed across these uprights, near the bottom and the top of the car. The distance between these opposite cross-pieces is now carefully measured, and pieces of board are cut for braces about an inch longer than this space, so that they will have to be driven home with considerable force. The braces are toe-nailed in place, to prevent their falling, if they should chance to loosen in the bumping of the car. When thus loaded and braced, the contents are absolutely immovable, yet each package is separated from its neighbors, on all sides, by a layer of cold air, which, when it becomes warmed by the hot fruit, rises, and is carried by the currents thus generated to the ice, where it is quickly cooled again, and where it deposits the moisture that 
may have been taken up from fruit. This rapid circulation of the air is very important, and the ice, instead of making the fruit damp, as might at first be thought, really serves to dry it very effectually."

\section{THE APPLE CROP AND MARKET}

The following notes on the apple crop and market are taken from the American Agriculturist Year Book, I898, p. 500.

"Probably in no branch of agriculture have greater ad-

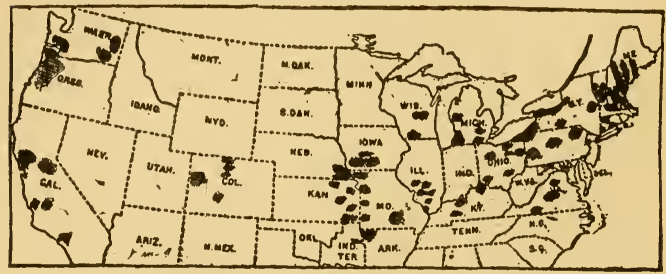

FIG. 6I-APPLE DISTRICTS OF THE UNITED STATES

vances been made than in fruit growing. Comparing the old days when 'book farmin' "was indifferently regarded, with to-day's progressive study of soil characteristics, fertilization, cultivation, and the use of insecticides and fungicides, marked changes have taken place. And nowhere more pronounced than in apple growing. The successful orchardist who raises apples for profit has long since left the ranks of those who pay little or no attention to the needed requisites indicated. On the other hand, he makes it a thorough business from the planting or grafting of the trees to the harvesting and marketing of the fruit.

"While what is known as the commercial apple belt, producing the surplus crop for winter markets, has long been 
confined to a group of comparatively few states, marked progress has been made in recent years, and new and highly promising orchard sections developed. The old time 'apple belt' includes New England, New York, Pennsylvania, Ohio, and Michigan. The newer orchard sections of increasing prominence and importance include the Ozark territory of southern Missouri and northern Arkansas, southwestern Iowa, eastern Nebraska, and Kansas, Colorado, and the Pacific coast, where some of the finest specimens are found. These states, together with isolated sections elsewhere, are giving intelligent attention to apple growing, where climate and soil are right.

"In the distribution of the winter apple crop, the eastern states, Canada, and Michigan, have been, as a rule, largely drawn upon to make up deficiencies in the middle west and northwest. The crop of hard varieties suitable for winter use is deficient in some of the central states and in most of the southern. A general criticism applying to nearly all sections where temperatures are cool, is the fact that too much summer and autumn fruit is produced, finding indifferent outlet, often at unremunerative prices. In the same line, there is still urgent need of more intelligent work among orchardists in the care of trees and in battling insect and fungus pests in order to secure perfect fruit.

"In the absorption of the apple crop through consumptive channels, the first to disappear is autumn fruit, and inferior to common stock generally, the poorest going to the cidermill, large quantities of better grade to evaporators. Prior to and following the harvest of winter varieties, there is interested buying on the part of country shippers and city dealers, entire orchards often being contracted long before the beginning of autumn. Farmers and orchardists now so generally understand practicable methods of storing and keeping fruit at home, that an important part of the crop is so cared for, this depending upon market conditions. The remainder is barreled and put away for later use, much of it in ordinary storage, and enormous quantities in the aggregate in coldstorage plants in the large towns and cities, where equable 
temperatures just above the freezing-point are maintained. Fruit can thus be kept almost indefinitely, and if properly selected and packed at the beginning of the season, will emerge from the warehouse late in the winter or early spring in practically perfect condition. The generally recognized standards of winter apples include such varieties as Baldwin, Greening, Northern Spy, Spitzenburg, and Russet. Among other popular and good selling apples in their season may be placed King, Pippin, Bellflower, Gravenstein, Jeniton, and Winesap.

"The export trade in winter apples has in recent years assumed such proportions as to be eminently important in the final distribution of the crop, and highly encouraging, meaning, as it does, a very liberal outlet to foreign countries. The quantity of apples that can be thus shipped depends very largely upon the home crop and prices, and supplies of fruit abroad. When our crop is short and prices high, exports are restricted; on the other hand, during a recent season the United States and Canada together shipped 3,000,00o barrels apples, the bulk of these going to the United Kingdom, but an important part to northern Europe. One of the encouraging features of the situation is the growing demand latterly for apples, both fresh and evaporated, for Germany, Belgium, France, and even Austria. Almost all the apples exported are in barrels, but experiments are being made in shipping in boxes; in fact, a considerable business in the latter is done each year on the Pacific coast, the Oriental trade favoring California, Oregon, and Washington apples packed in boxes.

"Among the best sellers in the foreign countries are King and Newtown Pippin, although the bulk of apples sent abroad comprise such standbys as Baldwin, Spy, Greening, and Russet. Indiscriminate packing and shipping is a mistake too often niade in exporting. It should be remembered that foreign buyers demand sound fruit well selected and properly packed; nothing else should be shipped abroad. Ocean freights on apples, Boston or New York to Liverpool, are usually 40 cents to 70 cents per barrel. Selling charges in Liverpool are close to 15 cents, this including dockage, town dues, insurance, advertising, sampling, and labor in handling. 
In addition is the 5 per cent commission on sales. Suppose, for example, a parcel of roo barrels Baldwin, well packed, sells at 16 shillings per barrel, equal to about $\$ 3.85 ; 5$ per cent commission on this would be I 9 cents, to which may be added the 15 cents, total about $3+$ cents, this representing charges for selling a barrel of apples after reaching Liverpool. As a rule, apples landing at English markets are sold at auction, and quick disposition is made of the entire shipload, the fruit going in lots of 20 barrels and upward. Great Britain always has a small to moderate crop of apples; also imports fair quantities from northern Europe during the autumn, and in early spring Australia sends some apples to the mother country. But in the main, the chief dependence is on the United States and Canada. which ship freely during the winter season, or from October to March inclusive. Ocean freights on apples, Boston or New York to Hamburg, the leading German market, are usually 70 cents to 75 cents per barrel, occasionally as low as 60 cents. The ocean freight on evaporated apples has declined recently to the level of 15 cents to 20 cents per roo pounds to both Hamburg and Bremen.

"Enormous quantities of dried apples, largely in the evaporated form, are each year shipped to foreign countries, doing much to relieve the home markets. This class of business has never been on a firmer footing than now, those engaged in the trade catering in an intelligent manner to foreign requirements. Last year's exports were unprecedented at nearly 3I,000,000 pounds. This was made possible by the low prices of fresh fruit from which the product was made, and the excellent reputation the goods enjoyed. The magnitude of the business is governed largely, but not wholly, by domestic prices, and when these are low exports are greatly stimulated. A large part of the goods shipped are dried on wood rather than zinc frames, this being a requisite in securing recognition in some of the European markets, notably that of Germany. After the empire just named, the Nether lands, France, Belgium, and the United Kingdom are our best customers, with, of course, more or less fruit going from Pacific coast ports to the Orient and southern hemisphere." 


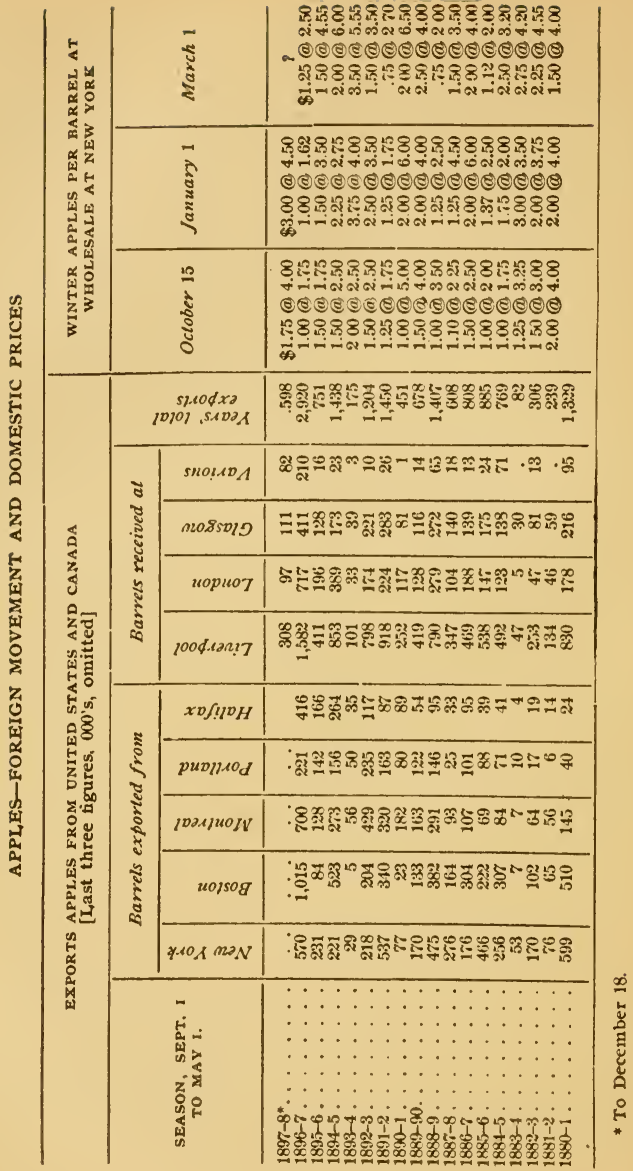


F.XPORTS-DRIEI APPI,KS FROM TNITED STATES

\begin{tabular}{|c|c|c|c|c|c|}
\hline YEAK & ENDEL & JUNE 30 & Pounds & Total value & Average i'alue' \\
\hline $\begin{array}{l}1896 \\
1896 \\
1895 \\
1894 \\
18913 \\
1892 \\
1891 \\
1894 \\
1889 \\
1868 \\
1887 \\
1886 \\
1885\end{array}$ & : & $\begin{array}{l} \\
\therefore \\
\therefore \\
\therefore \\
\therefore\end{array}$ & $\begin{array}{r}30,883,921 \\
26,691,963 \\
\tau, 085,946 \\
2,846,615 \\
\tau, 996,819 \\
26,042,063 \\
6,973,168 \\
20,861.462 \\
2,2,102,5 \% 9 \\
11,803,161 \\
8,130,396 \\
10,473,183 \\
18,416,573\end{array}$ & $\begin{array}{r}\$ 1,356,578 \\
1,340,507 \\
461,214 \\
168,054 \\
482,085 \\
1,288,102 \\
409,605 \\
1.038,682 \\
1,201,070 \\
812,682 \\
413,363 \\
548,434 \\
1,062,859\end{array}$ & $\begin{array}{c}4.39 \mathrm{c} . \\
5.02 \\
6.50 \\
5.90 \\
6.02 \\
4.57 \\
5.87 \\
1.96 \\
5.43 \\
7.73 \\
5.08 \\
5.23 \\
5.77\end{array}$ \\
\hline
\end{tabular}

\section{THE CRANBERRY CROP}

The following facts and figures concerning the cranberry crop are taken from the American Agriculturist Year Book, I 898: 513 .

"Cranberries are grown extensively in but two states, although a few others devote some attention to the crop practically and experimentally. Probabiy nine-tenths of the cranberries found in the markets are produced in New Jersey and eastern Massachusetts, notably Cape Cod. Wisconsin was quite a producer some time ago, but in recent years the crops have been small, as the bogs were greatly damaged or destroyed by fires. A few cranberries are grown in Connecticut, Maine, New York, and Michigan, and portions of the Pacific northwest have for several years been experimenting with this crop. Canada produces some cranberries, and would market a good many more were conditions favorable. The cranberry thrives best on a natural black peat or muck bottom, where plenty of sand is available, and a requisite is a liberal supply of running water.

"The establishment of a cranberry bog requires a large 
expenditure of labor and money, and even then the business is hazardous unless thoroughly understood and cared for. The question of drainage is a highly important une. Cranberry vines are flooded in the fall, beginning in October, and this is continued as late as May, when the water is drawn off. This furnishes protection from frosts, and in some degree from insect pests. Blossoms appear in June, and with an ample supply of moisture the fruit ripens in September and October. The cranberry frequently suffers both in fruit and vine from the ravages of insects, and the crop is also subject to damage through fungus diseases and drought. Upon being harvested the fruit is carefully cleaned, screened, and assorted, due attention being given to the process of ripening or coloring previous to placing in barrels and crates. Cold storage for keeping cranberries during early autumn is not generally favored; successful growers prefer to store the fruit in a cool, dry bog house or cellar, disposing of it before cold weather sets in. In the states where mostly grown, law governs the size of package. In Massachusetts, New Jersey, and Wisconsin the crate must hold one bushel, or thirty-two quarts dry measure. New Jersey law provides that the standard crate shall be $7 \frac{1}{2} \times 12 \times 22$ inches, capacity 1980 cubic inches, with the barrel three times a crate. or containing ninety-six quarts. The Massachusetts barrel is one hundred quarts; efforts were made in a recent legislature to reduce this to ninety-six quarts.

"The cranberry crop is practically all consumed at home. Commendable efforts were made a few years ago, mostly by New Jersey growers, to build up an export trade, but nothing of consequence has ever been accomplished. A special agent spent several months in England teaching best methods of cooking and serving the fruit, and creating a favorable impression, yet cranberries are still regarded in the light of a novelty abroad, an occasional season showing perhaps five thousand bushels exported from this country. Under the Dingley law an ad valorem duty of 25 per cent has been placed upon foreign cranberries, which will serve to shut out possible shipments from Canada. 
"Comparatively few sizable bogs have come into bearing the last year or two, crop and market conditions not favorable to any rapid extension, although enough new territory is being developed to probably more than offset loss in other directions. The west, notably Wisconsin and Michigan, are showing renewed interest in cranberry growing, yet they furnish only a small percentage of total supply. The Wisconsin cranberry section is confined to the neighborhood of Greenlake and Wood counties, and eastward to Green Bay and Lake Michigan. The heavy counties in Massachusetts are Plymouth and Barnstable. with considerable attention given the industry in Middlesex, Norfolk, and Bristol counties. Rhode Island and Connecticut raise a few cranberries, and there is a small acreage across the Sound in Long Island. The Massachusetts state census for 1 S95, issued at the close of 1897 . points to a remarkable increase in the production of cranberries in Plymouth County, placing the yield at 104,192 barrels against only $14,30 S$ ten years earlier, in 1885 . The Massachusetts crop of $\mathrm{I} S 95$ is reported at $\mathrm{r} 69,583$ barrels, with a value of $\$ 1,038,7 I_{2}$. The leading counties of New Jersey are Burlington, Atlantic, Ocean, Monmouth, and Camden, although a number of others turn off a good many berries in the aggregate.

"An average crup of cranberries is about 600,000 bushels, more than half of this being found in New England, and most of the remainder in New Jersey. The crop of 1897 was short and one of the smallest in years, approximating 425,000 bushels against 560,000 in 1896 and 640,000 bushels in 1895 . The weather in the spring of 1897 was unfavorable. the crop developed poorly, and was eventually damaged by blight, scald, and insects. Prices one year with another are governed to some extent by the supply of other fruit, notably apples. A short crop of the latter in 1897 stimulated the demand for cranberries; the enormous apple yield of 1896 , with attendant phenomenally low prices, hurt the sale of the acid fruit that year. Extended missionary work is still necessary before American consumers will regard cranberries as a staple articie of food rather than a luxury." 
CRANBERRY CROPS ANI MARKETS BY YEARS

\begin{tabular}{|c|c|c|c|c|c|c|c|}
\hline \multirow{2}{*}{ 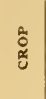 } & \multicolumn{4}{|c|}{ CROP IN BUSHELS } & \multicolumn{3}{|c|}{$\begin{array}{c}\text { BOSTON PRICE PER } \\
\text { BUSHEL }\end{array}$} \\
\hline & $\begin{array}{l}\text { New } \\
\text { England }\end{array}$ & Nerwey & West & Total & Oct. & Jan. & May \\
\hline 1897 & 256,000 & 120,000 & 50.000 & 415,000 & $\$ 2.00$ & $\$ 2.50$ & \\
\hline 1896 & 380.000 & 130,000 & 50,000 & 560,000 & 1.75 & 1.35 & $\$ 1.00$ \\
\hline 1895 & 420,000 & 210,000 & 10,000 & 640,000 & 2.50 & 2.00 & 2.50 \\
\hline *1894 & $18 \tilde{3}, 000$ & 200,000 & 25,000 & 410,000 & 2.50 & 3.00 & 075 \\
\hline 1893 & 575,000 & 325,000 & 100,000 & $1,000,000$ & 1.50 & 2.50 & 3.00 \\
\hline 1892 & 375,000 & 160,000 & 65,002 & 600,000 & 1.50 & 2.25 & 3.00 \\
\hline 1891 & 480,000 & $250,(00)$ & 30,0601 & $\tau 60,000$ & 2.00 & 2,25 & 2.00 \\
\hline 1890 & 375,000 & 200,000 & $2: 25,000$ & 800,000 & 2.25 & 3.00 & 3.50 \\
\hline 1889 & 350,0110 & 200,000 & 70,000 & 620,000 & 2.00 & 3.00 & 5.00 \\
\hline 1888 & 360,000 & 225,000 & 100,000 & $58,5,000$ & 2.00 & 225 & 1.00 \\
\hline $188 \pi$ & 306,000 & 164,000 & 141,000 & 611,000 & 2.00 & 3.00 & 300 \\
\hline 1886 & 275,000 & 234,000 & 31,000 & 540,000 & 1.50 & 2.75 & 4.00 \\
\hline 1885 & 280,879 & 198.125 & $2(64,432$ & 743,436 & $1 ; 0$ & 1.40 & $0 . \pi 5$ \\
\hline 1884 & 130,583 & 121,648 & 24,783 & 280,014 & 3.00 & 4.75 & 2.75 \\
\hline 1883 & 141,964 & 118,524 & $135,50 t$ & 395,995 & 3.00 & 3.75 & 550 \\
\hline 1882 & 193,664 & $78,50 \%$ & 50,000 & $3: 2,1 \pi 1$ & 3.00 & 4.50 & 3.50 \\
\hline 1881 & 160,825 & 157,014 & 143,186 & 461,025 & 2.00 & 4.00 & 3.00 \\
\hline 1880 & 250,500 & $128,70()$ & 113,430 & 492,630 & 2.00 & 2.00 & 1.00 \\
\hline
\end{tabular}

* Figures for 1894 and earlier years from anuual reports American Cranberry Growers' Association.

\section{HANDLING SOUTHERN GRAPES}

Prof. F. S. Earle makes the following remarks on the question of picking and packing grapes at the south (Alabama Experiment Station Bulletin I Io: 75, December, 1900).

"Southern grown grapes are more perishable than the same kind grown at the north, because they ripen during the heat of midsummer. For this reason marketing must be expedited in all possible ways. Only a few hours can be allowed for wilting. Those picked in the morning should be packed in the afternoon, and those picked in the afternoon packed early the following morning, and when packed they should be rushed into refrigerator cars as rapidly as possible. Prices for 
southern grapes are too low at present to justify express shipments, and the business can only be permanently successful at those points where enough are grown to load refrigerator cars.

"Grapes are best gathered in flat wooden trays or boxes. Twenty by thirty inches by six inches deep is a convenient size. The bunches are cut from the vines with clippers made for the purpose or with a sharp knife, and are placed carefully, two layers deep, in these boxes. When full they may be hauled to the packing house on a spring wagon. The two layers of clusters will not fill them quite full, so they may be safely piled one on top of another in hauling. At the packing house they should be stacked up in an open, well-ventilated space, and should be crossed in piling so that the ends of each box are freely exposed to the air. In a few hours the stems will have wilted a little so that they will settle together limply. They are now ready for packing. The Climax basket is more used than any other package for grapes, and, everything considered, it is probably the best. It is an oblong basket with a board bottom, solid veneer sides, a solid veneer cover, and a wooden hoop handle. The usual sizes hold about five and eight pounds." 



\section{N D E X}

PAGE

PAGE

Accounts sales . ......... 10

Advertising . . . . . . . . . 24

Alle1, Mrs., storage house . . . . 144

Alwood, W. B., storage house . . 131

American fruit package . . . . 73

Apple barrel. . . . . . . . . 74

Apple crop and marktt , . . . 212

Apples in boxes . . . . . . . 83

Apples, packing . . . . . . . 67

A pples, picking . . . . . . . . 45, 46

A pple shippers' rules. . . . . 187

A pples stored in pits . . . . . . 120

Apricots, picking . . . . . . . . 44

Barrel presses . . . . . . . . . 69

Barrel, standard

186

Beach, S. A., o11 apple storagt . . 14i

Berry package . . . . . . . . . . 77

Blackberries, picking . . . . 43, 46

Hoxes for apples . . . . . . . . 83

Brooks Bros'. storage house . . . 148

Burton, J. A., storage house . . 149

Canadian apple exports . . . . 175

Canadian fruit honse . . . . . 128

Canadian frnit marks act . . . . 183

Canadian frnit-package law . . . 182

Canadian fruit shipments . . . . 13

Canning . . . . . . . . . $3^{8}$

'Caves" for storage....... I2I

Check for pickers . . . . . . . 53

Cherries, picking . . . . . . 44, 46

Cider making . . . . . . . . . 40

Coburn, W. S., storage house . . 147

Commission charges . . . . . . 206

Commission men . . . . . . . . 8

Connission merchants . . . . I89

Cooperative marketing . . . . 17

Connpetition ......... . . 5

Competition, inversion of . . . . 21

Cost of cold storage... . . . 99

Cranberries . . . . . . . 217

Crates for fruits ....... . 8 7

Culls, use of ........ 63

Currants, picking . . . . 4, 4, 46

Daybook for pickers. . . . . 52

Delaware fruit-package law... ISo

Delaware peach basket..... Si

Distrust among fruit shippers . . 20

Drying fruit . . . . . . . $3^{2}$

"Dugouts" for storage . . . . 121

Exports of apples . . . 2 216

Exports of apples, Canadian . . 175

Exports of dried apples. . . . 217

Exports of fruit, U. S. . . . 171

Evaporating fruit . . . . . 32

Faville-Hall storage house . . . 101

Ferris, Dean, on storing vege-

tables .......... 115

Filling the package . . . . . 67

First-grade fruit . . . . . . . 61

Fisk, J. M., storage house . . . 128

Foreign market ........ 12

Fruit market. . . . . . . . 1

Fruit-package laws . . . . . 176

Gooseberries, picking . . . 43, 46

Grades of fruit . . . . . . 63

Grading fruit . . . . . . . 59

Grape basket . . . . . . . 79

Grapes, picking ..... . . 44, $4^{8}$

Grapes, sorting ...... 60

Grapes, southern ..... 220

Grape storage ....... 112

Growing fruit ....... . 7

Hale's package label . . . . . 99

Handling fruit for storage. . 96-109

Hill, A. H., packing shed . . 153

Hill, A. H., storage house . . . 165

Hill, H. H., storage house . . 148

Hillside storage . . . . . 157

Home market ........ 22

lce refrigeration . . . . . . . 99

Inports of fruits, U S. . . . 171

Improvised storage ...... 14 S 
Judgment in grading

Keeping quality .

Kinney, T. I.., storage house .

Ladders for picking . . . . . .

Laws regarding fruit packages

I,ean-to storage

Managing pickers

Margin of profit .

Market problems

Marks on packages

Massachusetts berry-basket law .

Mcclelland, J. S., storage house .

Mechanical graders

Mechanical pickers

Mechanical refrigeration

Michigan peach basket .

Missouri apple barrel law

Moore, Trevor, on grape storage

Morris, O. M., on storage in pits .

National League Commission Merchants.

New Jersey peach basket law . . Iso

New York apple, pear, quince, and potato barrel law

New York small-fruit package law . . . . . . . . . 177

Nova Scotia apple barrel . . . 75

Nova Scotia apple house . . . . 138

Ontario storage house . . . . . 148

Orchard wagons . . . . . 50

Over-production of fruit . . . 25

Package laws ........ 176

Packages.......... 73

Packages, filling . . . . . . 67

Packages, geueral summary . . . 88

Packing fruit ........ 59

Paper headings for barrels . . 76

Peach packages ....... so

Peaches, packing . . . . . 69

Peaches, picking. . . . . 44, 46

Picking ........ . 43

Picking for storage. . . . . . 96

Picking machines . . . . . . . 49

Picking receptacles . . . . . ${ }_{46}^{6}$

Picking tools . . . . . . 48

Pits for storage. . . . . . 117

Plums, packing ...... 70
1'AG B

Plums, picking. . . . . 44, 46

Pools . . . . . . . . . 17

Prices, philosophy of ..... 25

Production and price. . . . 25-27

Production of fruits, Massachusetts ........ 3

Production of fruits, U. S. . . . 2

Prunes, California . . . . . 172

Puncli-card for pickers . . . 53

Quality in fruits ........ 6

Raspberries, picking . . . . . 43, 46

Refrigerator cars . . . . 20 ${ }^{7}, 209$

Requirements for storage . . . 95

Sears, F. C., on apple storage . . 138

Season of fruits....... . 30

Selling associations ...... 17

Shepherd's apple box..... 84

six-basket carrier . . . . . . 82

"Slacks" . . . . . . . . 16

Smith, J. S., grape storage . . . 114

Sorting tables ........ 65

Spraying recommended..... 188

Stems on or off . . . . . . . 47

Storage of fruit . . . . . . 95

Strawberries, picking . . . 43, 46

supply and demand . . . . . . 26

Supply, conditions affecting . . . 27

Systems of storage . . . . . 97

Temperatures in storage . . . 110

Thousand-barrel storage house $\quad 162$

Transportation ... 8, 18, 27, 187

Utilization of wastes . . . . 3

Vegetables, storage of . . . . . ${ }^{115}$

Ventilation system of storage . . 106

Ventilators, arrangement of . . 107

Wagons for fruit . . . . . . . 50

Wall structure for storage house,

$125,14^{\circ}$

Wastes, utilization of . . . . 31

West Virginia storage houses . . 150

Wholesale and retail markets contrasted

Wilson, T. B., storage house . . 141

Wine naking ........ 40

Woolverton's a pple box . . . 85

Wrapping fruits....... . 89

Wright and Sons refrigeration . 103 


\section{STANDARD BOOKS}

.. PUBLISHED BY ..

\section{ORANGE JUDD COMPANY}

NEW YORK

52 \&ै 54 Lafayette Place
CHICAGO

Marquette Building

BOOKS sent to all parts of the world for catalog price. Discounts for large quantities on application. Correspondence invited. Brief descriptive catalog free. Large illustrated calalog, six cents : $\because$

\section{RECENT BOOKS BY THOMAS SHAW}

Professor of Animal Husbandry at the University of Minnesota, formerly Professor of Agriculture at the Ontar io sgricultural College.

\section{Animal Breeding}

The most complete and comprehensive work ever published on the subject of which it treats, and the first book of the kind ever given to the world which has systematized the subject of auimal breeding. The striking originality in the treatment of the subject is no less conspicuous than the superb order and regular sequence of thought from the beginning to the end of the book. Illustrated. $5 \times 8$ inches, 13 full-page plates, about 400 pages. \$1.50.

The Study of Breeds

Origin, history, distribution, characteristics, adaptability, uses, and standards of excellence of all the pedigreed breeds of cattle, sheep. and swine in America. The accepted text-book in colleges, and the authority for farmers and breeders. 387 pages, $5 \times 8$ inches, 60 fullpage plates. \$1.50.

\section{Forage Crops Other than Grasses}

How to cultivate, harvest, and use them. Indian corn, sorghum, clover, leguminous plants, crops of the brassica genus, the cereals, millet, field roots, etc. Intensely practical and reliable. 295 pages. Illustrated. $5 \times 8$ inches. \$1.00.

\section{Soiling Crops and the Silo}

The growing and feeding of all kinds of soiling crops, conditions to which they are adapted, their plan in the rotation, etc. Best methods of building the silo, filling it, and feeding ensilage. Illustrated. $5 \times 8$ inches, 378 pages. $\$ 1.50$. 


\section{Swine Husbandry}

By F. D. COBбRN. New, revised, and enlarged editition. A practical mannal for the breeding, rearing, and management of swine, and the prevention and treatment of their diseases. In preparing this work it has been the object of the author to condense in one volume, from all available sources, the ideas and conclinsions of the most practical, successful, and observant men who have followed the business in our time, and in our own conntry, acting upon the belief that no one man, or auy lialf-dozen men, know all there is worth knowing on a subject so extensive and important as that of Swine Husbandry. It is the fullest and freshest compendium relating to swine breeding yet offered. Cloth, $12 \mathrm{mo}$. Illustrated. \$1.50.

\section{Home Pork Making}

The art of raising and curing pork on the farm. By A. W. Furton. A complete guide for the farmer, the conntry butcher, and the suburban dweller, in all that pertains to hog slaughtering, curing, preserving, and storing pork product-from scalding vat to kitchen table and dining-room. Fully illustrated. Cloth. 5ocents.

\section{Shepherd's Manual}

By HENRY STEwART. A practical treatise on the sheep for American farmers and sheep-growers. The results of personal experience of many years with the characters of the various modern breeds of sheep, and the sheep-raising capabilities of the United States and Canada-and the careful study of the diseases to which our sheep are chiefly subject, with those by which they may eventually be afflicted through unforeseen accidents-as well as the methods of management called for under our circumstances, are here gathered. Illustrated. Cloth, 12mo. \$1.00.

\section{Cabbage, Cauliflower, and Allied Vegetables}

By C. I. AlleN. A practical and reliable guide to the successful raising of cabbage, cauliflower, broccoli, collards, Brussels sprouts, kale, and kohlrabi, from "seed to harvest." Illustrated. $5 \times 8$ inches, 128 pages. Cloth. 50 cents.

\section{Hedges, Windbreaks, Shelters, and Live Fences}

By E. P. PowelL. The planting, growth, and managemeut of liedge plants for country and suburban homes. Illustrated. $5 \times 8$ inches, 140 pages. Cloth. 50 cents.

\section{Landscape Gardening}

By F. A. WAUGH. A treatise on the general principles goveruing outdoor art, with sundry suggestions for their application in the commoner problems of gardening. Illustrated. $5 \times 8$ inches, 150 pages. Cloth. 5o cents.

\section{Plums and Plum Culture}

By Prof. F. A. WAEGH. A complete manual for fruit-growers, nurserymen, farmers, and gardners, on all known varieties of plums and their successful management. A monograph of the plums cultivated in and indigenous to North America, with a complete account of their propagation, cultivation, and utilization. It is one of the most complete, accurate, and satisfactory works ever written for the field of Anerican horticulture. Illustrated. $5 \times 8$ inches, 371 pages. Cloth. \$1.50.

\section{Hemp (Cannabis sativa)}

By S. S. Boyce. A practical treatise on the culture of hemp for seed and fiber, with a sketch of the history and nature of the hemp plant. All tine various operations connected with hemp culture are so plainly and clearly described as to enable any one to make a success of hempraising. Illustrated. $5 \times 8$ inches, 122 pages. Cloth. so cents. 
By LUTE WILCOX. A handbook for the practical application of water in the production of crops. A complete treatise on water supply, canal construction, reservoirs and ponds, pipes for irrigation purposes, flumes and their structure, methods of applying water, irrigation of field crops, the garden, the orchard and vineyard; windmills and pumps, appliances and contrivances. Illustrated. Cloth. $5 \times 8$ inches. \$1.50.

\section{The New Rhubarb Culture}

By J. E. MorsE and G. B. FiskE. A complete guide to dark forcing and fieid culture. Illustrated. 5 × 8 inches, abont 112 pages. Cloth. 50 cents.

\section{The New Egg Farm}

By H. H. STODDARD. A practical, reliable manual upon producing eggs and poultry fot market as a profitable business enterprise, either by itself or connected with other branches of agriculture. It tells a:l about how to feed and manage, how to breed and select, incubators and brooders, labor-saving devices, etc., etc. I $2 \mathrm{mo}, 33 \mathrm{I}$ pages. 140 original illustrations. Cloth. \$t,00.

\section{Turkeys and How to Grow Them}

Edited by HERBERT MYRICK. A treatise on the natural history and origin of the name of turkey; the various breeds, the best methods to insure success in the business of turkey growing. With essays from practical turkey-growers in different parts of the United States and Canada. Illustrated. Cloth, 12mo. \$1.00.

\section{Tobacco Leaf}

By J. B. KILlEbrew and Herbert MYRICK. Its culture and cure, marketing and manufacture. A practical handbook on the most approved methods in growing, harvesting, curing, packing, and selling tobacco, with an acconnt of the operations in every department of tobacco manufacture. Upwards of 500 pages and 150 original engravings. $\$ 2.00$.

\section{Handbook of the Turf}

By S.IMCEL L. BOARDMAN. A treasury of information for horsemen, embracing a compendium of all racing and trotting rules; laws of the states in their relation to horses and racing; a glossary of scientific terms; the catchwords and phrases used by great drivers, with miscellaneous information about horses, tracks, and racing. Cloth. 12110. \$1.00.

\section{American Grape-Growing and Wine-Making}

By GEORGF HISMAxx. New and enlarged edition. With contributions from well-known grape-growers, giving wide range of experience. Illustrated. $5 \times 8$ inches, 277 pages. Cloth. \$1.50.

\section{The Fruit Garden}

By P. BARRY. A standard work on fruit and fruit trees, the anthor having had over thirty years' practical experience at the head of one of the largest nurseries in this country. Invaluable to all fruit growers. Illustrated. Cloth, $12 \mathrm{mo}$. \$1.50.

\section{Small Fruit Culturist}

By ANDREW S. FELLER. The book covers the whole ground of propagating small fruits, their culture, varieties, packing for market, etc. Illustrated. $5 \times 8$ inches. Cloth. \$I.00.

\section{Gardening for Profit}

By PFTER IIFNDFRSON. The standard work on market and family gardening. The successful experience of the author for more than thinty vears, and his willingness to tell, as he does in this work, the secret of his success for the benefit of others, enables hin to give most valuable information. The book is profusely illustrated. Cloth, 12mo. \$1.50. 
Market Gardening and Farm Notes.

By BURNETT I,ANDRETh. Experiences and observation for both North and South, of interest to the amateur gardener, trucker and farmer. A novel feature of the book is the calendar of farm and garden operations for each month of the year; the chapters on fertilizers, transplanting, succession and rotation of crops, the packing, shipping, and marketing of vegetables will be especially useful to market gardeners. Cloth, $12 \mathrm{mo}$. \$1.00.

\section{The Nut Culturist.}

By ANDREW S. FOLLER. A treatise on the propagation, planting and cultivation of nut-bearing trees and shrubs adapted to the climate of the United States, with the scientific and common names of the fruits known in commerce as edible or otherwise useful nuts. Intended to aid the farmer to increase his income without adding to his expenses or labor. Cloth, $12 \mathrm{mo}$. $\$ 1.50$.

\section{Greenhouse Management.}

By L. R. TAFT. This book forms an almost indispensabie companion volume to "Greenhouse Construction." In it the author gives the results of his many years' experience, together with that of the most successful florists and gardeners, in the management of growing plants under glass. So minute and practical are the various systems and methods of growing and forcing roses, violets, carnations, an 1 all the most important florists' plants, as well as fruits and vegetables described, that by a careful study of this work and the following of its teachings, failure is almost impossible. Illustrated. Cloth, 12mo. \$1.50.

\section{Bulbs and Tuberous-Rooted Plants.}

By C. L. ALLEN. A complete history, description, methods of propagation and full directions for the successful culture of bulbs in the garden, dwelling or greenhouse. The illustrations which embellish this work have been drawn from nature, and have been engraved especially for this book. The cultural directions are p.ainly stated, practical and to the point. Cloth, 12mo. \$1.50.

\section{Ornamental Gardening for Americans.}

By ELIAS A. LoNG, landscape architect. A treatise on beautifying homes, rural districts and cemeteries, A plain and practical work, with numerous illustrations and instructions so plain that they may be readily followed. Illustrated. Cloth, $12 \mathrm{mo}$. \$1.50.

\section{The American Merino. For Wool or for Mutton.}

By STEPhen Powers. A practical and most valuable work on the selection, care, breeding, and diseases of the Merino sheep, in all sections of the United States. It is a full and exhaustive treatise upon this one breed of sheep. Cloth, 12mo. \$1.50.

\section{The Hop-Its Culture and Care, Marketing and Manufac- ture.}

By HERBERT MYRICK. A practical handbook on the most approved methods in growing, harvesting, curing and selling hops, and on the use and manufacture of hops. The result of years of research and observation, it is a volume destined to be an authority on this crop for many years to come. It takes up every detail from preparing the soil and laying out the yard, to curing and selling the crop. Every line represents the ripest judgment and experience of experts. Size, $5 \times 8$; pages, 300: illustrations, nearly 150 ; bound in cloth and gold; price $\$ 1.50$, post paid. 


\section{Ginseng-Its Cultivation, Harvesting, Marketing, and Mar- ket Value.}

By MACRICE G. KAINS, with a short account of its history and botany. It discusses in a practical way how to begin with either seed or roots, soil, climate and location, preparation, planting and maintenance of the beds, artificial propagation, manures, enemies, selection for market and for improvement, preparation for sale, and the profits that may be expected. The booklet is concisely written, well and profusely illustrated, and should be in the hands of all who expect to grow this drug to supply the export trade, and to add a new and profitable industry to their farms and gardens, without interfering with the regular work. $12 \mathrm{mo}, 35$ cents.

\section{Land Draining.}

By MANLy Miles. A handbook for farmers on the principles and practice of draining, giving the results of his extended experience in laying tile drains. The directions for the laying out and the construction of tile drains will enable the farmer to avoid the errors of imperfect construction and the disappointment that must necessarily follow. Cloth, $12 \mathrm{mo}$. \$1.00.

\section{Practical Forestry.}

By ANDREW S. FULLER. A treatise on the propagation, planting and cultivation, with descriptions and the botanical and popular names of all the indigenous trees of the United States, and notes on a large number of the most valuable exotic species. \$1.50.

\section{Mushrooms. How to Grow Them.}

By WILLIAM FALCONER. This is the most practical work on the subject ever written, and the only book on growing mushrooms published in America. The author describes how he grows mushrooms, and how they are grown for profit by the leading market gardeners, and for home use by the most successful private growers. Engravings drawn from nature expressly for this work. Cloth. \$1,00.

\section{The Propagation of Plants.}

By ANDREW S. FULLER. Illustrated with numerous engravings. An eminently practical and useful work. Describing the process of hybridizing and crossing, and also the many different modes by which cultivated plants nay be propagated and multiplied.' Cloth, 12mo. \$1.50.

\section{Silos, Ensilage, and Silage.}

By Manly Mrles, M.D., F.R.M.S. A practical treatise on the ensilage of fodder corn. Containing the most recent and authentic information on this important subject. Illustrated. Cloth, 12mo. 50 cents.

\section{Play and Profit in My Garden.}

By E. P. ROE. The author takes us to his garden on the rocky hillsides in the vicinity of West Point, and shows us how out of it, after four years' experience, he evoked a profit of $\$ 1,000$, and this while carrying on pastoral and literary labor. It is very rarely that so much literary taste and skill are mated to so much agricultural experience and good sense. Cloth, 12mo. \$1.00.

\section{Grape Culturist.}

By ANDREW S. FULLER. This is one of the very best of works on the culture of the hardy grapes, with full directions for all departments of propagation, culture, etc., with 150 excellent engravings, illustrating planting, training, grafting, etc. Cloth, 12mo. \$1.5o. 




$$
\text { W } 205
$$


North Carolina State University LIbraries

SB360.W35

FRUIT HARVEST

III I I II STORING MARKETING A PRACTICA

IIIIIIIIII)

S02787808 |

502787808 P 